Fall 1937

\title{
1937 Cedrus Yearbook
}

\section{Cedarville College}

Follow this and additional works at: https://digitalcommons.cedarville.edu/yearbooks

Part of the Higher Education Commons, Organizational Communication Commons, and the Public Relations and Advertising Commons

\section{Recommended Citation}

Cedarville College, "1937 Cedrus Yearbook" (1937). Yearbooks. 72.

https://digitalcommons.cedarville.edu/yearbooks/72

This Book is brought to you for free and open access by DigitalCommons@Cedarville, a service of the Centennial Library. It has been accepted for inclusion in Yearbooks by an authorized administrator of DigitalCommons@Cedarville. For more information, please contact digitalcommons@cedarville.edu. 


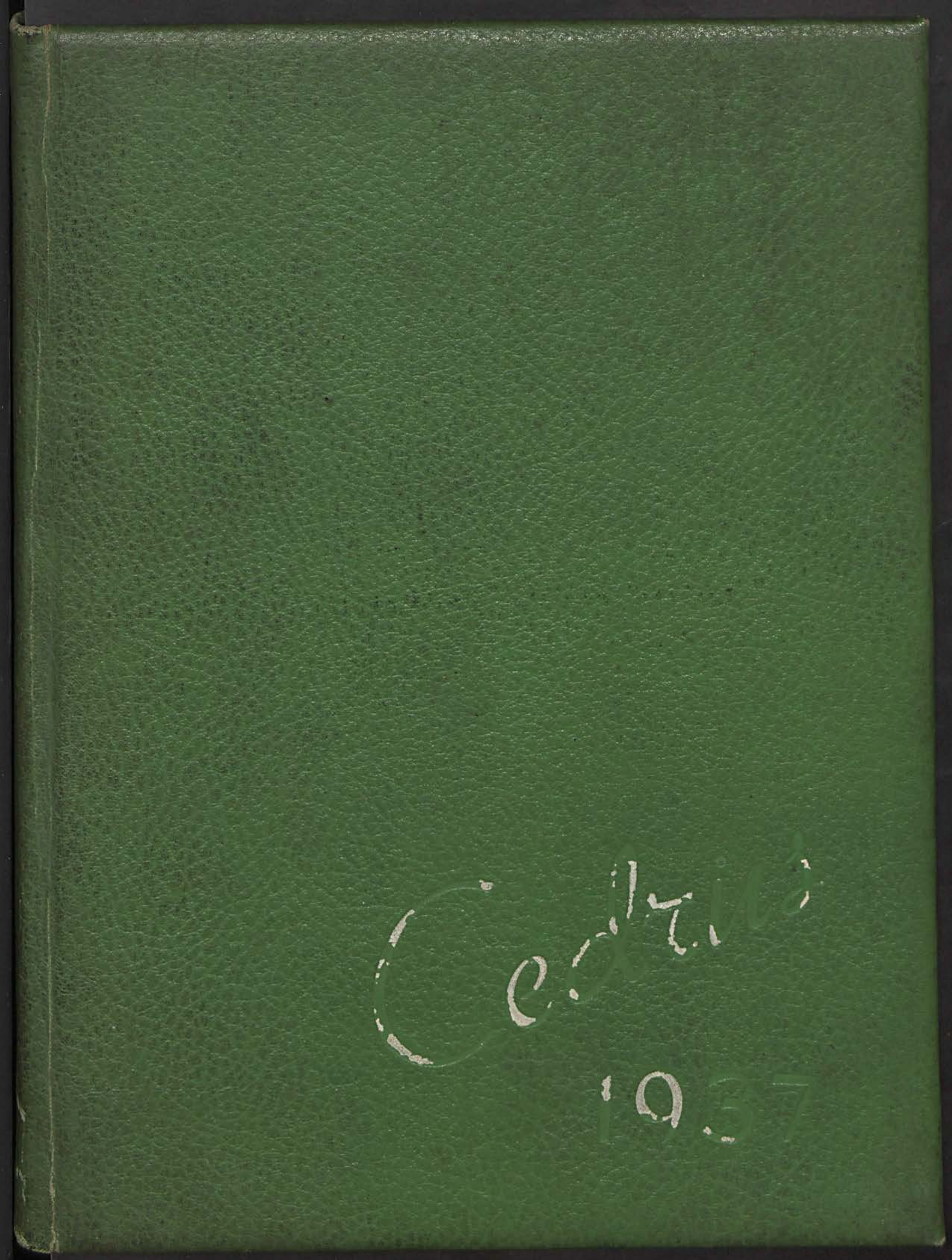




19)37 Cedsus 


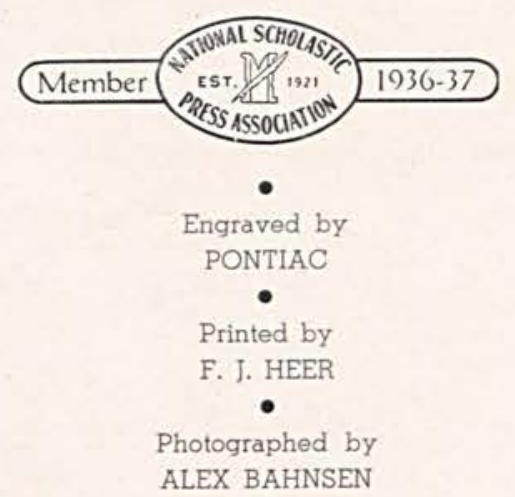




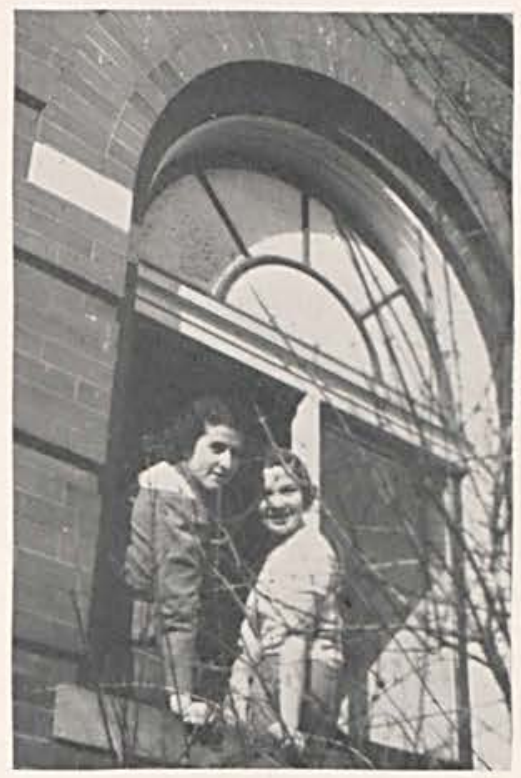

The CEDRUS of Nineteen Thirty Seven 

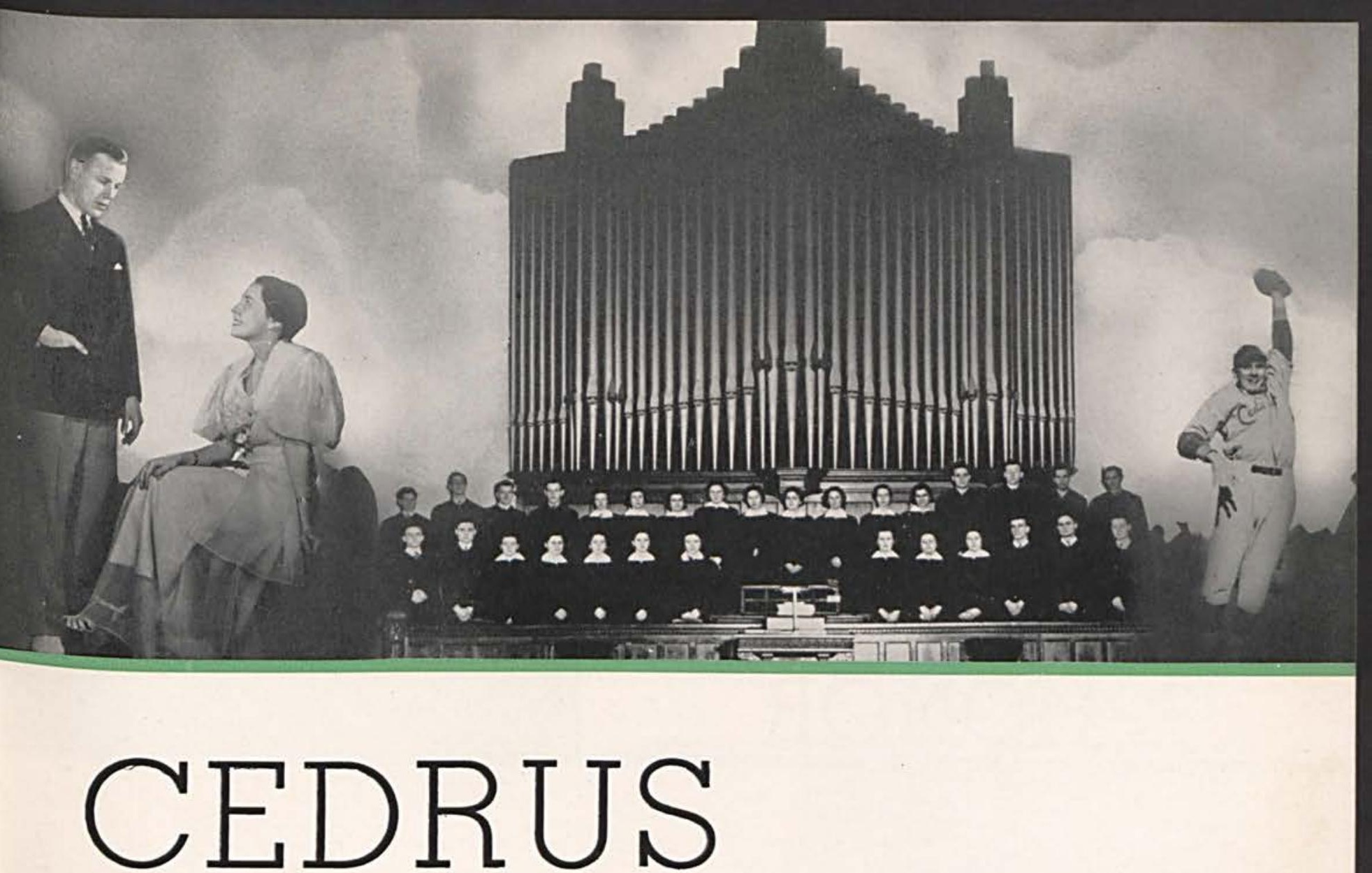

Hundred Thirty Seven

The staff of the 1937 Cedrus wishes to present to you this publication, a summary of the year's activities in Cedarville College. 
WE HONOR

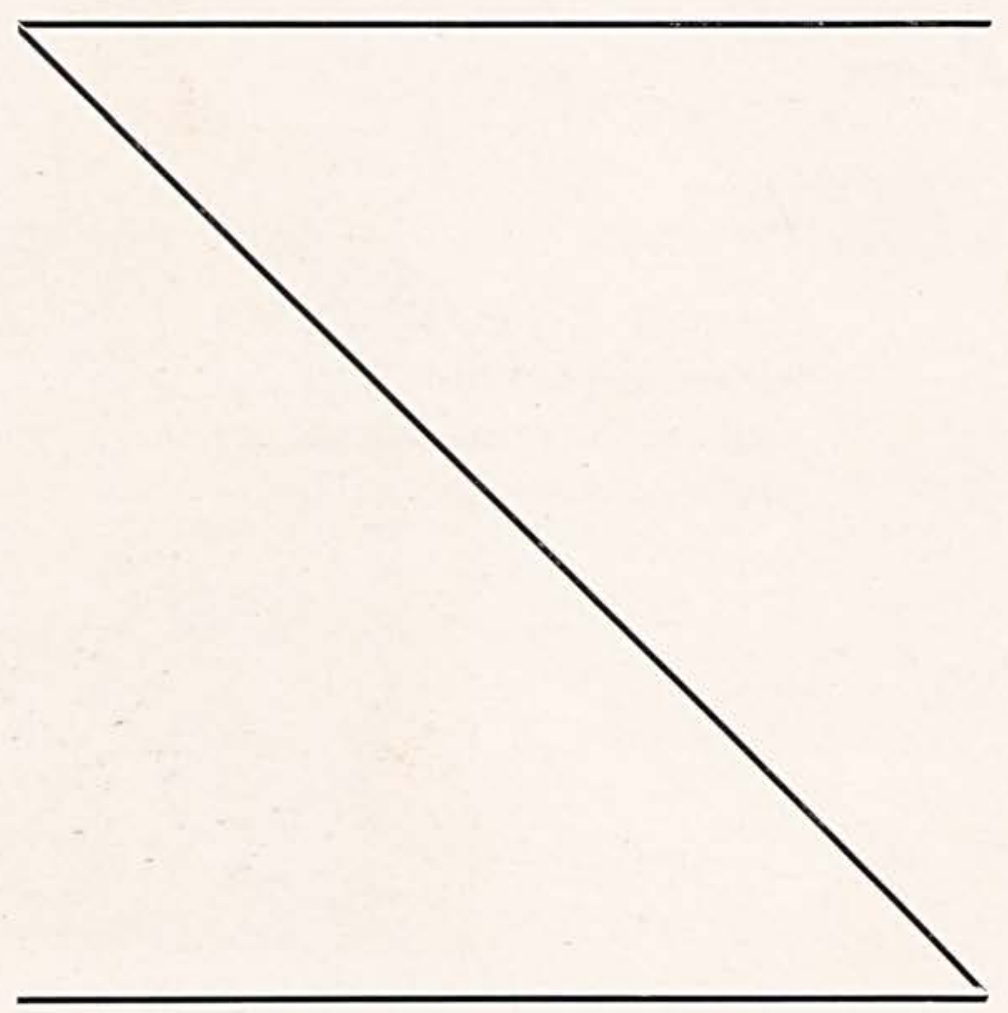



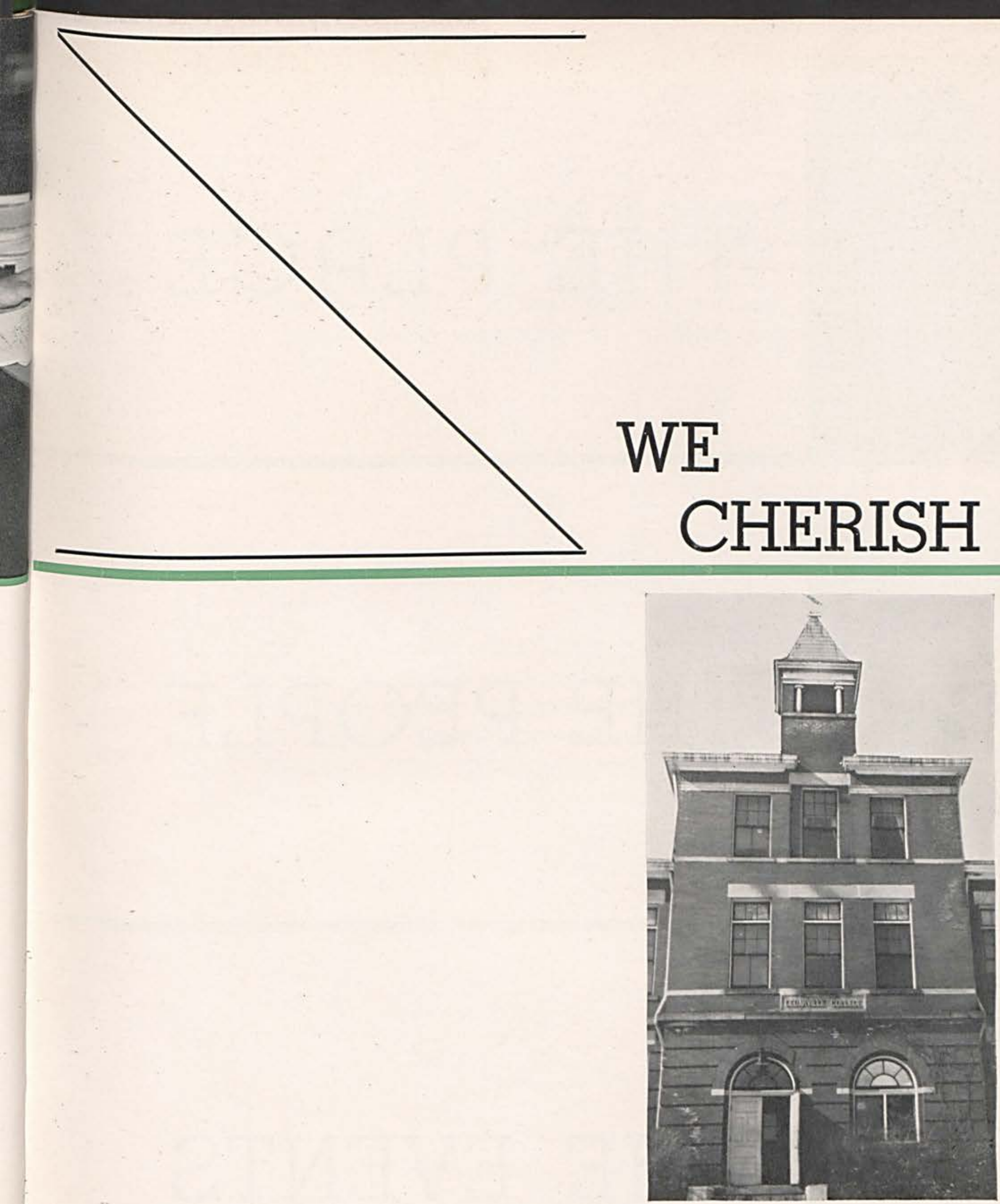
The campus of Cedarville College is dotted with beautiful trees, many of which are the original Cedars. In the midst of this beauty stands the stately buildings constantly reminding one of her standard of high scholarship.

The professors and students of the college work and play together, uniting their efforts into a symphony of achievement. Nowhere will one be able to find better harmony and friendship than in Cedarville College.

The student at Cedarville who wishes to enter into other activities will find a sufficient number of them to keep him busy throughout the college year. Extra-curricular activities are varied enough to suit every taste. 


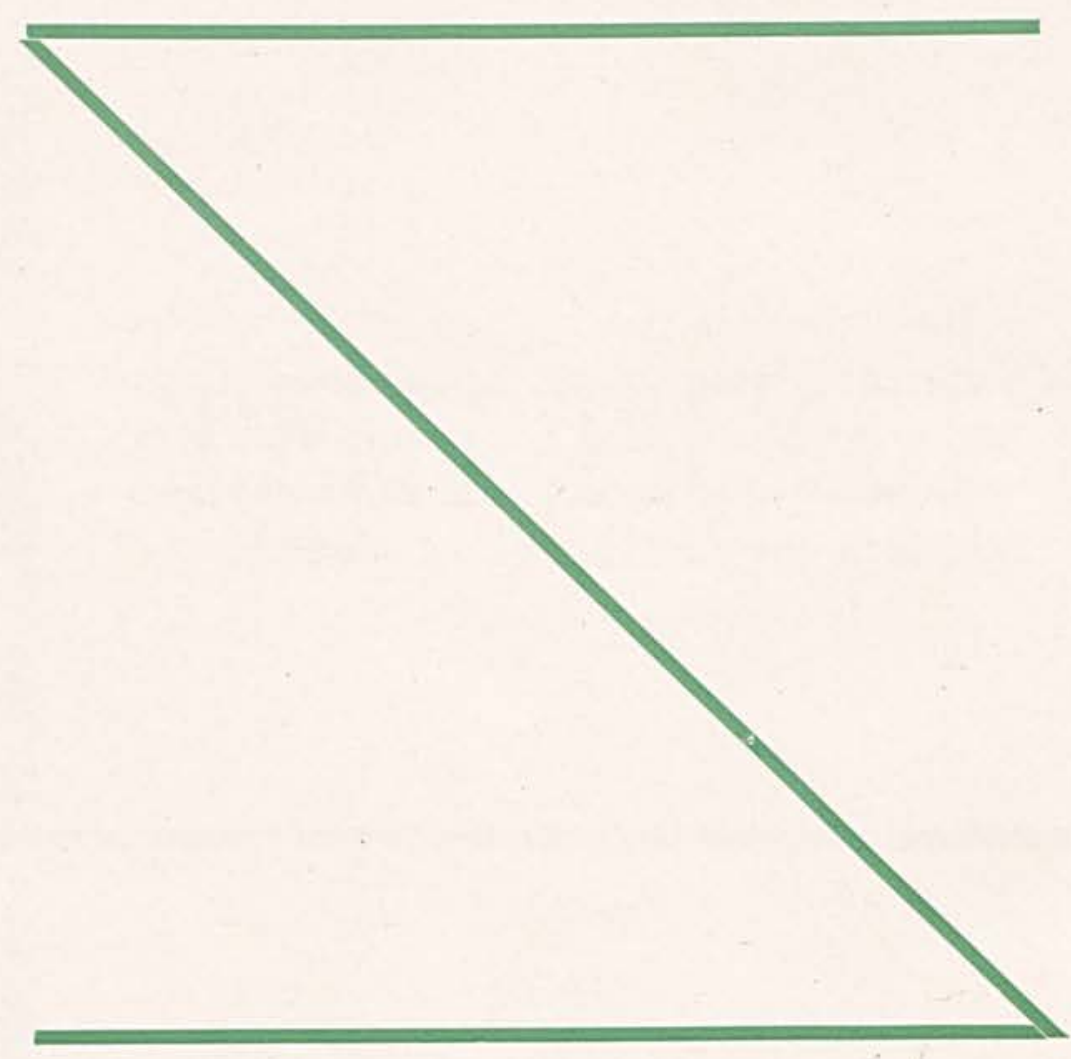


Book One

T H E P L A C E 
"OLD MAIN"

The College Administration Building
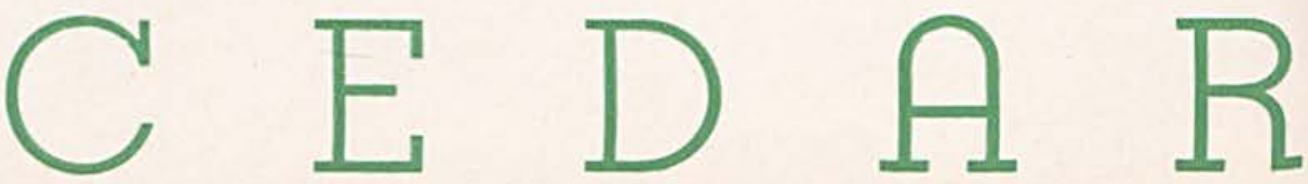


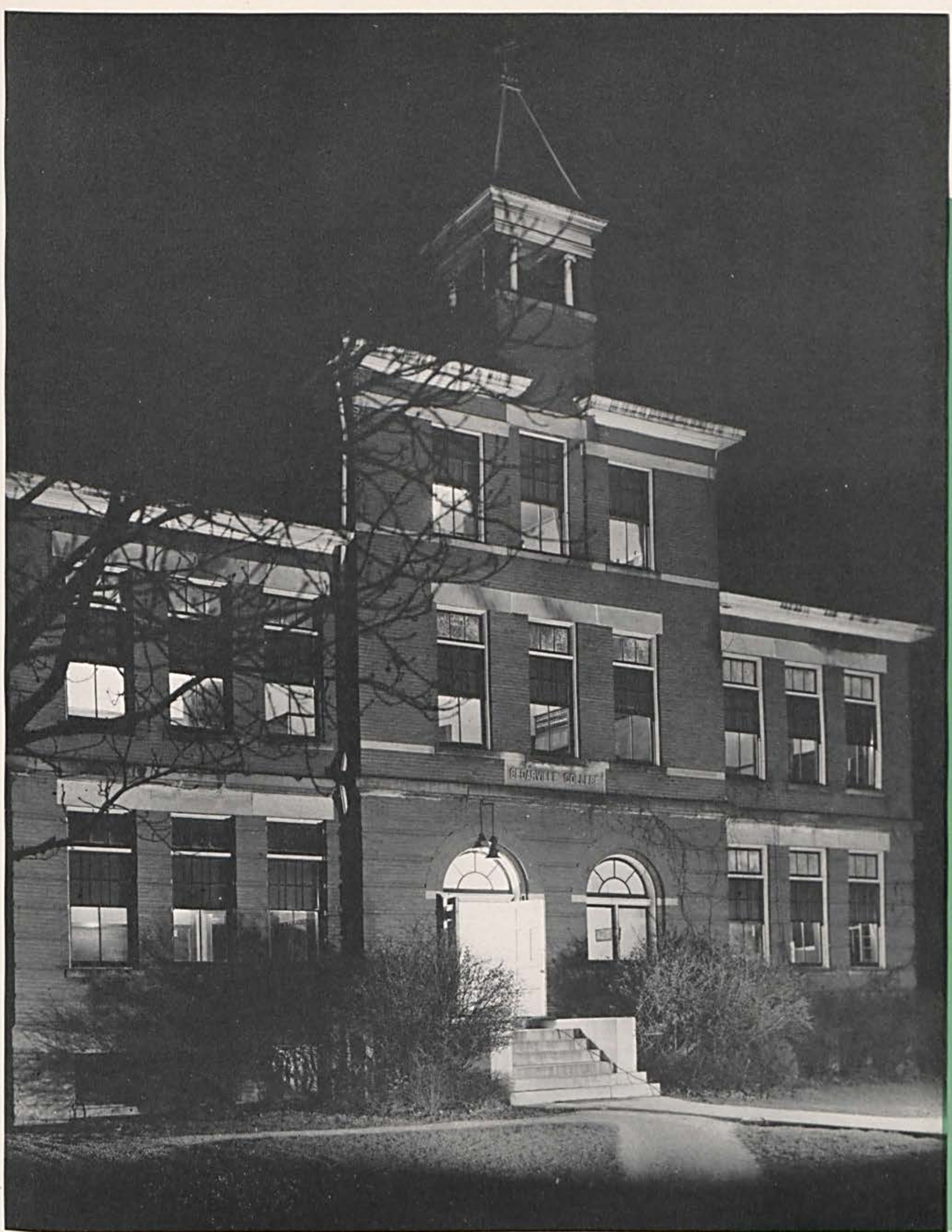




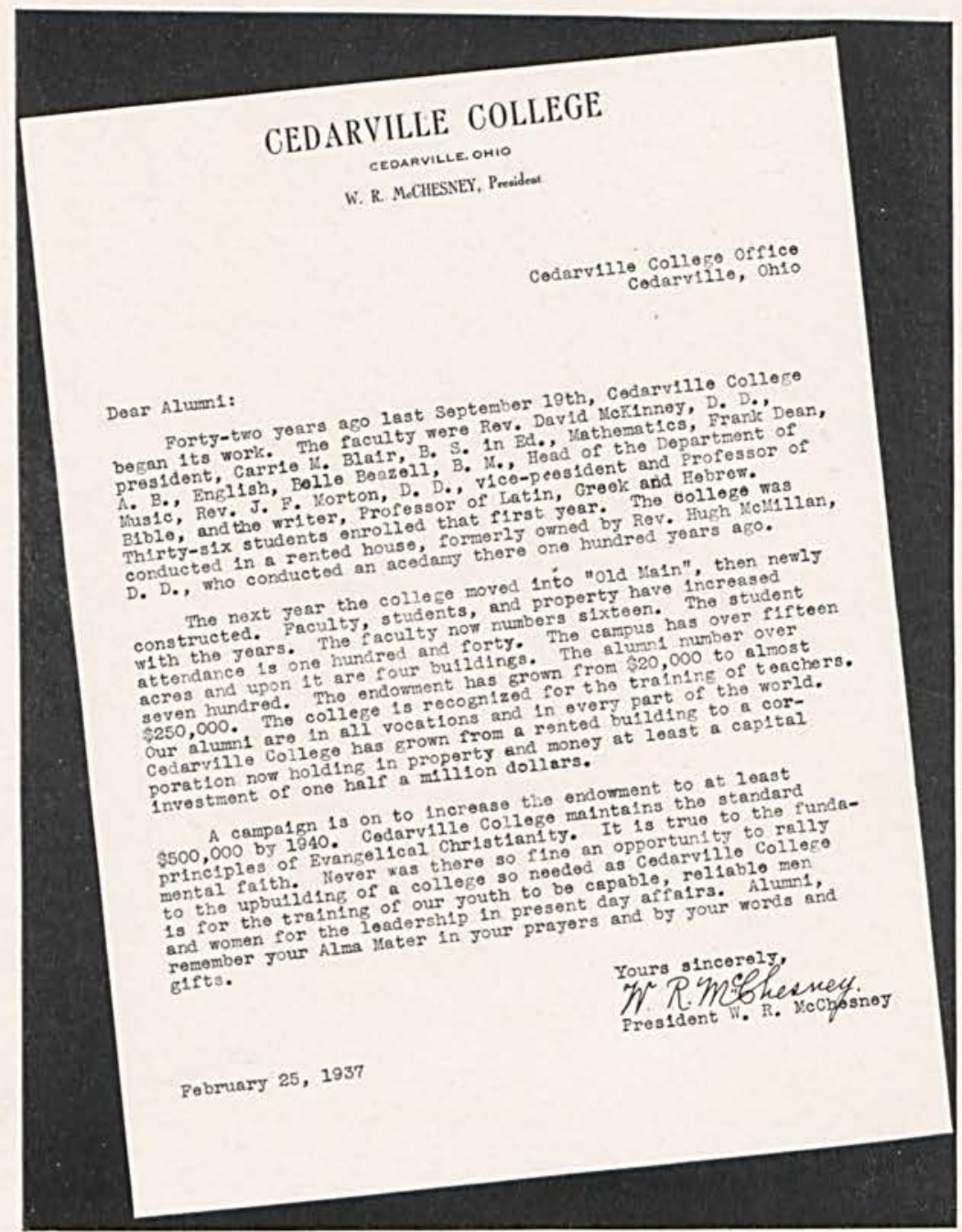

A. message from Dr. McChesney to all who are interested in... Cedarville College 
President

W. R. McCHESNEY

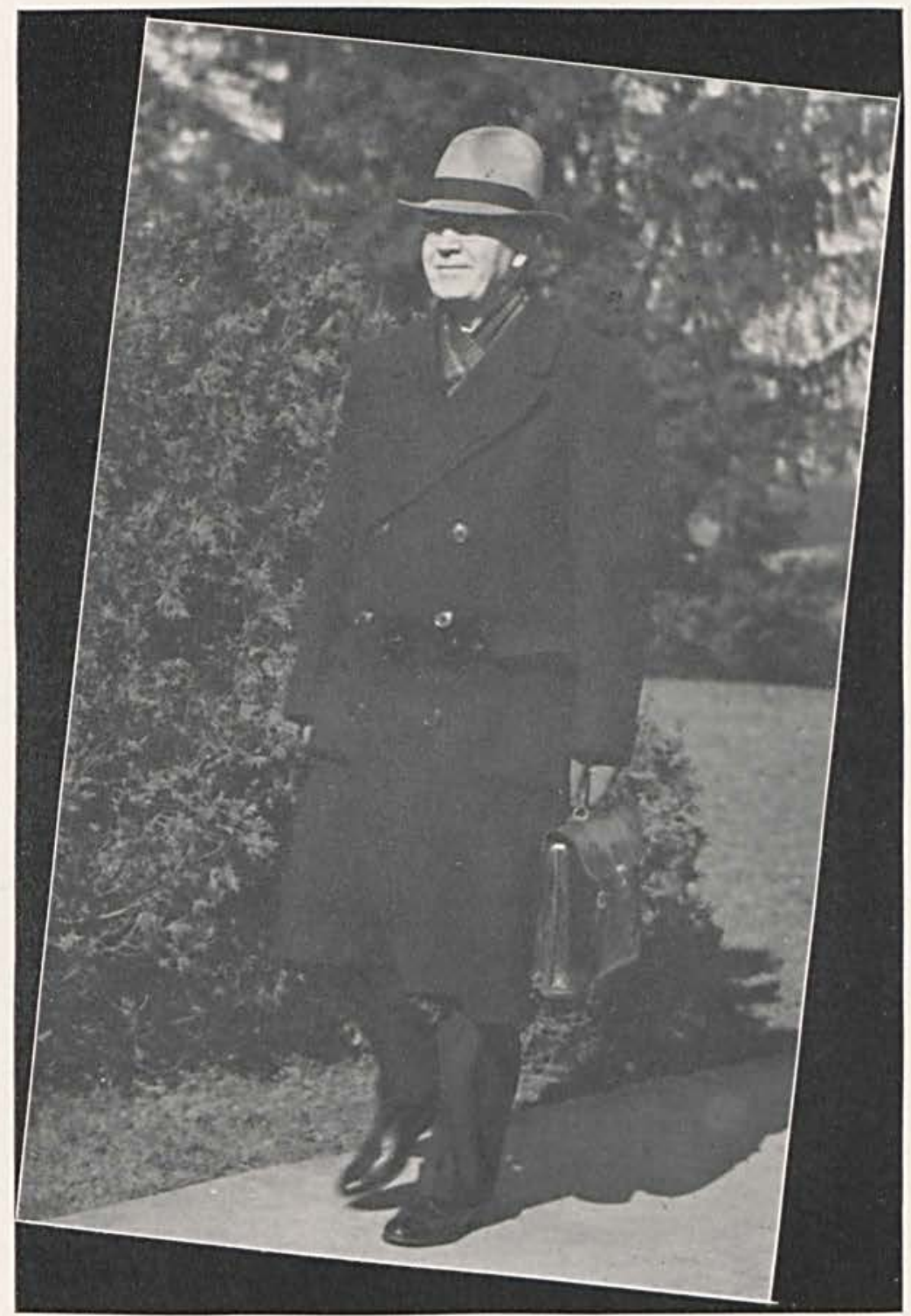




\section{Through The Years at}
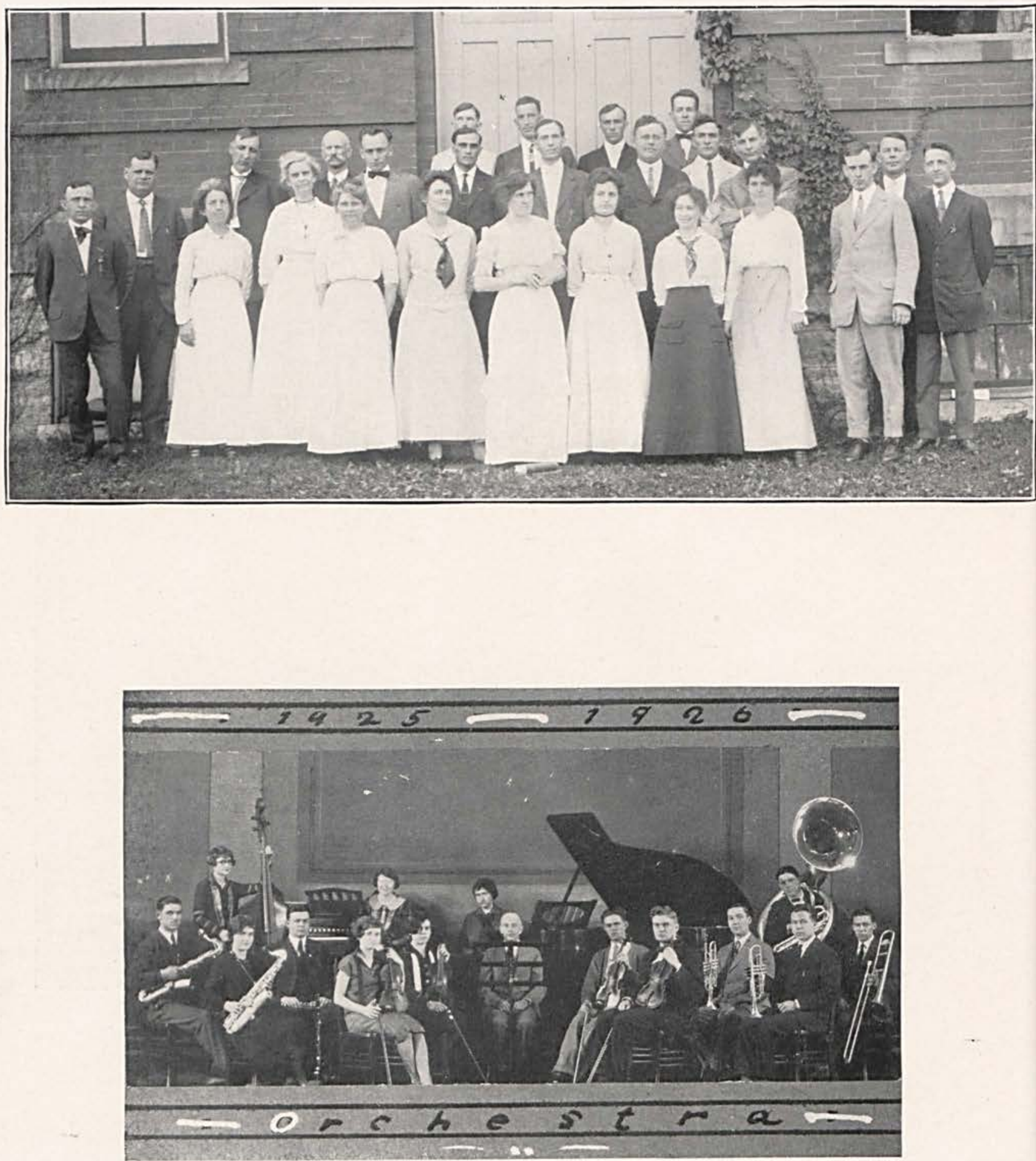

CEDARVILIE 
A series of contrasts presented for your edification and enjoyment
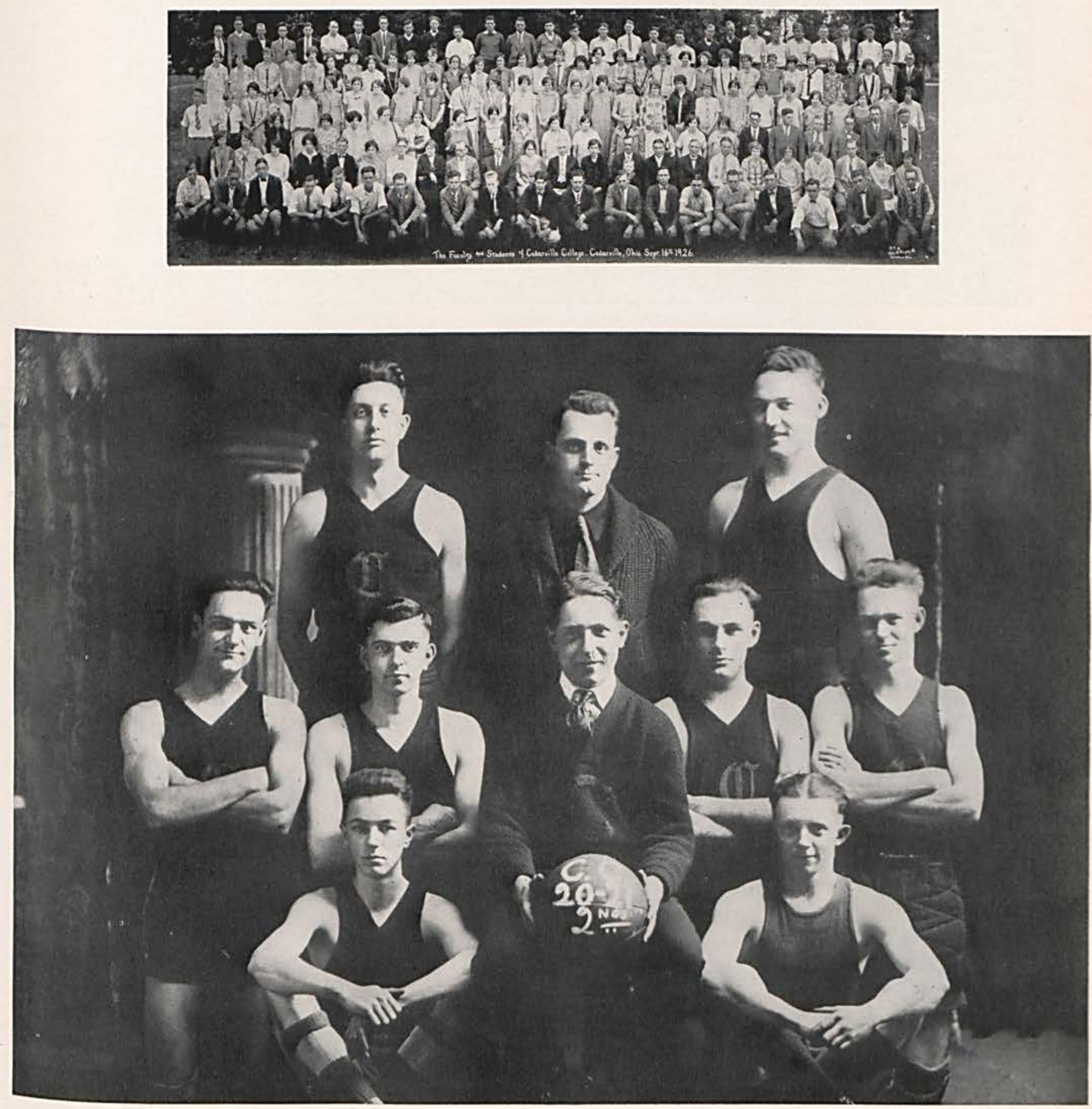


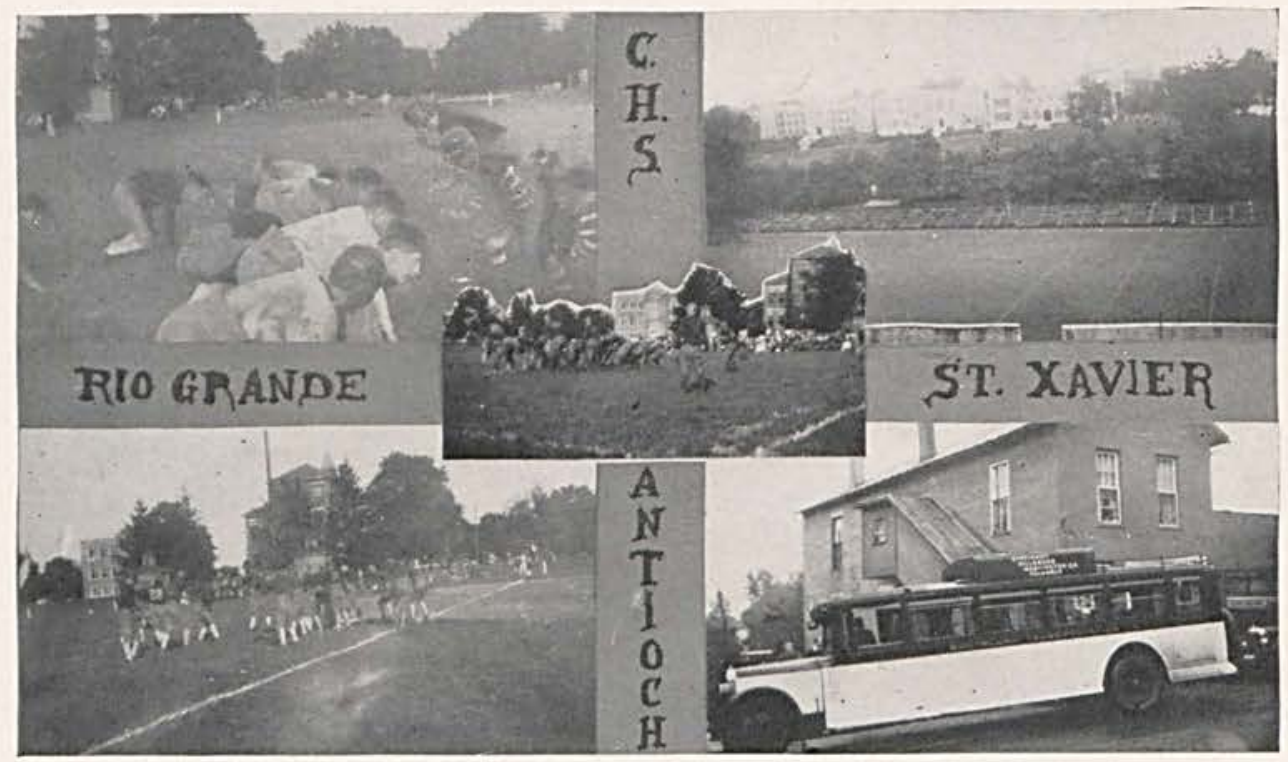

A
WEALTH

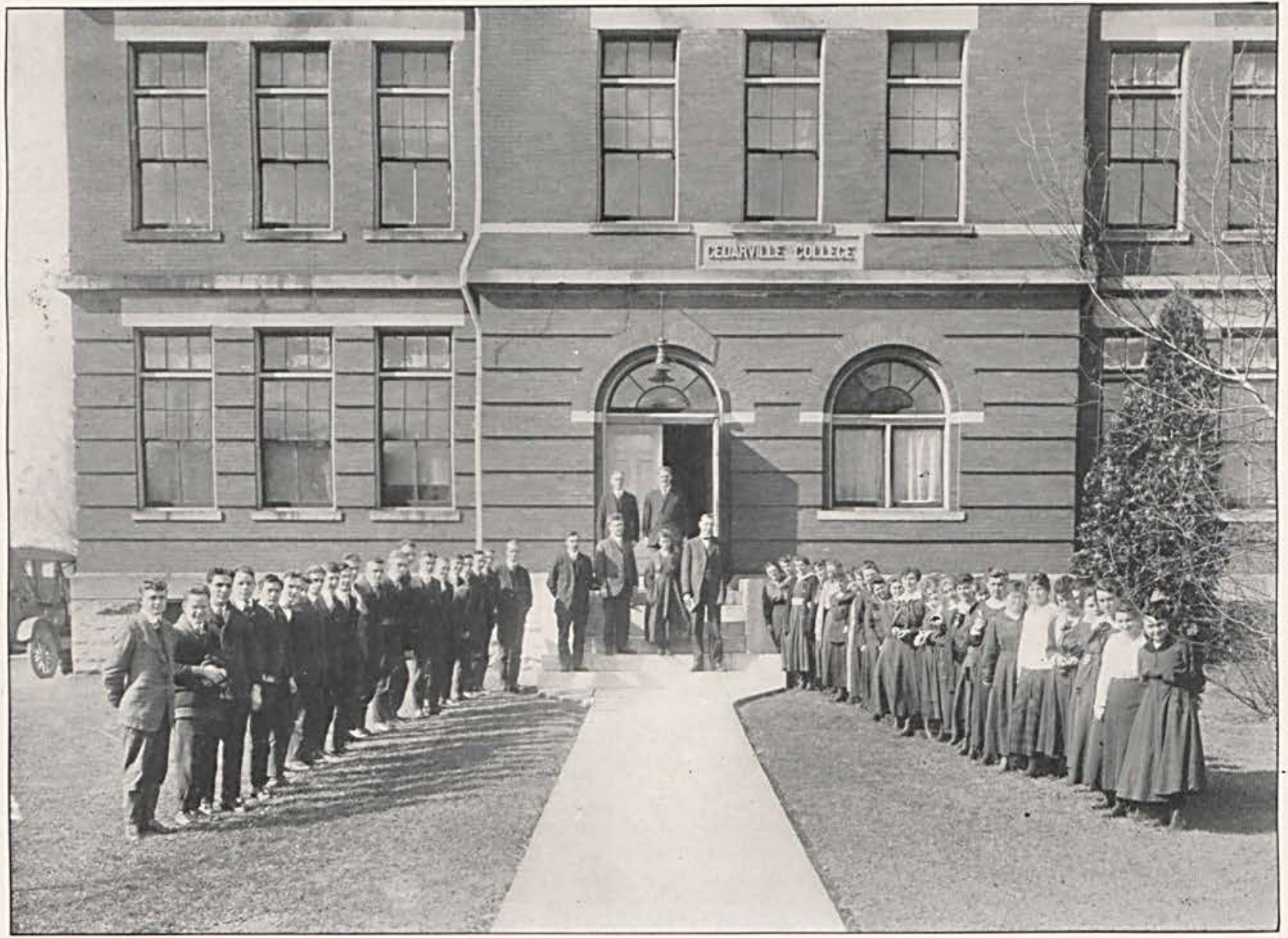

CEDARVILLE 


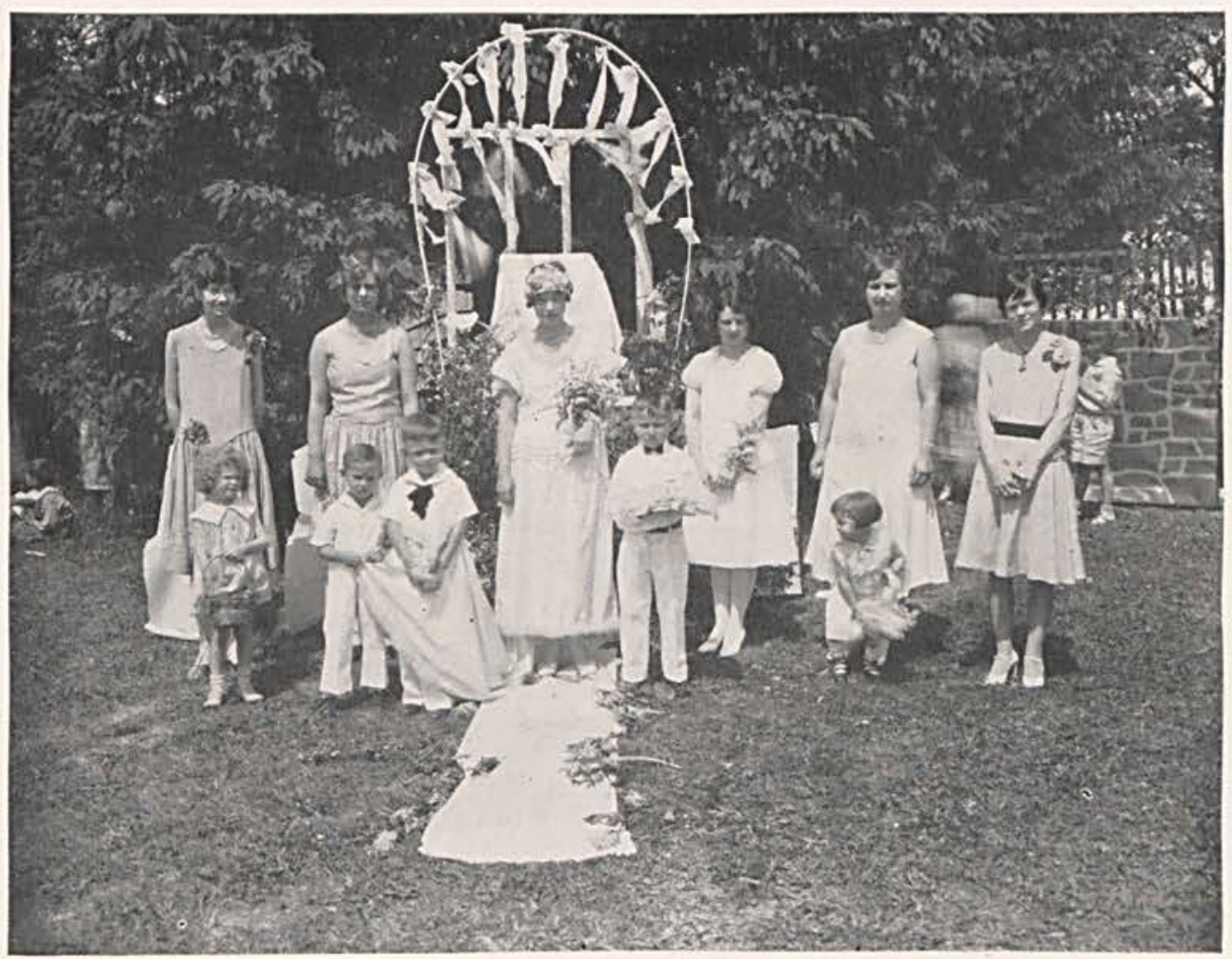

OF
HERITAGE

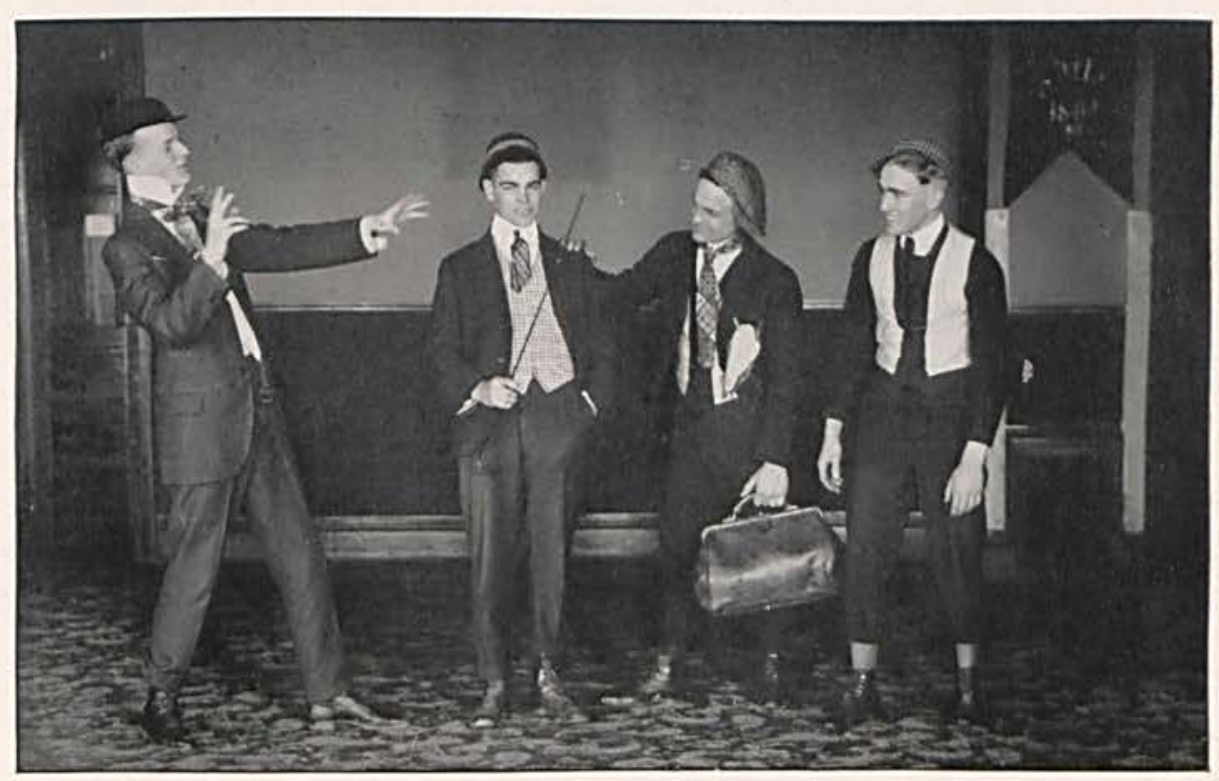




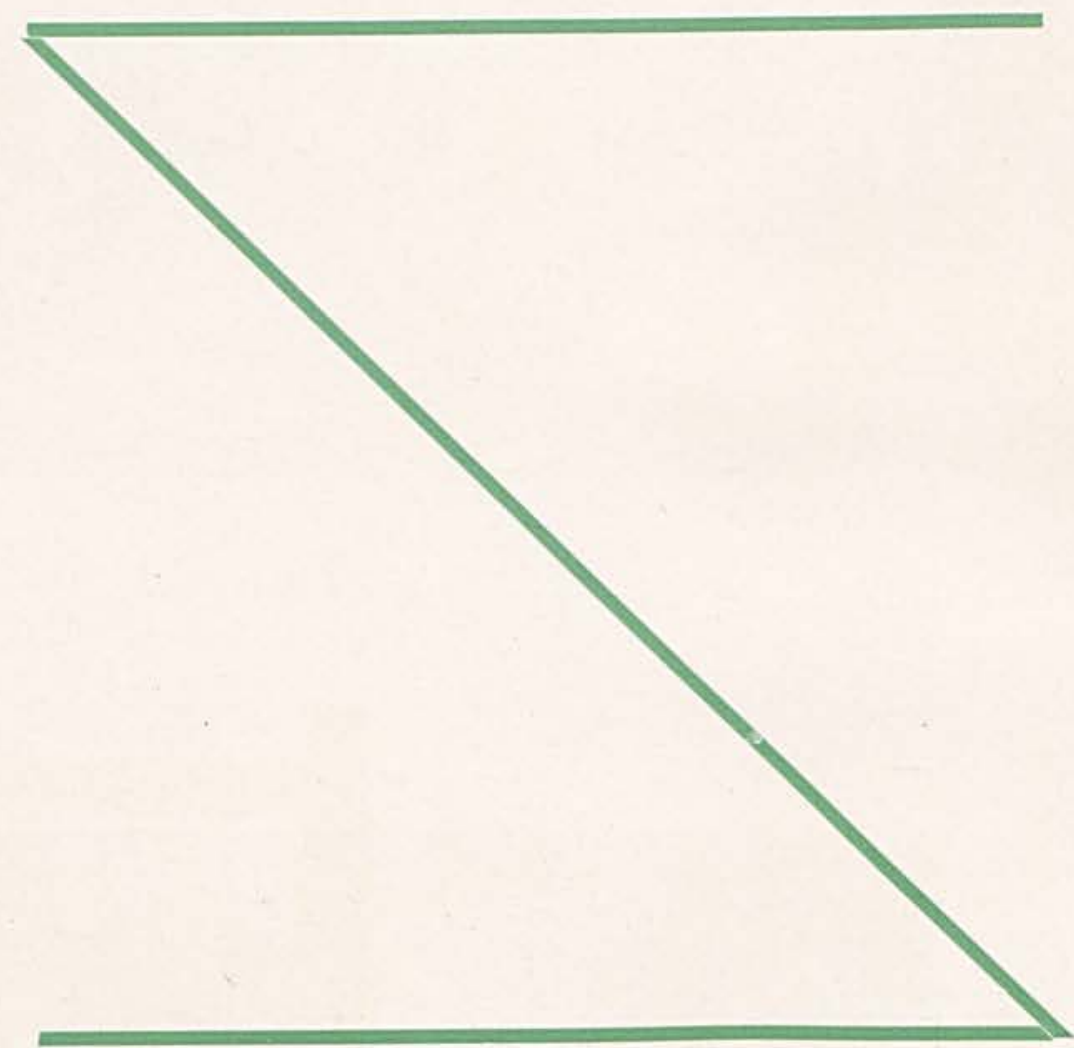




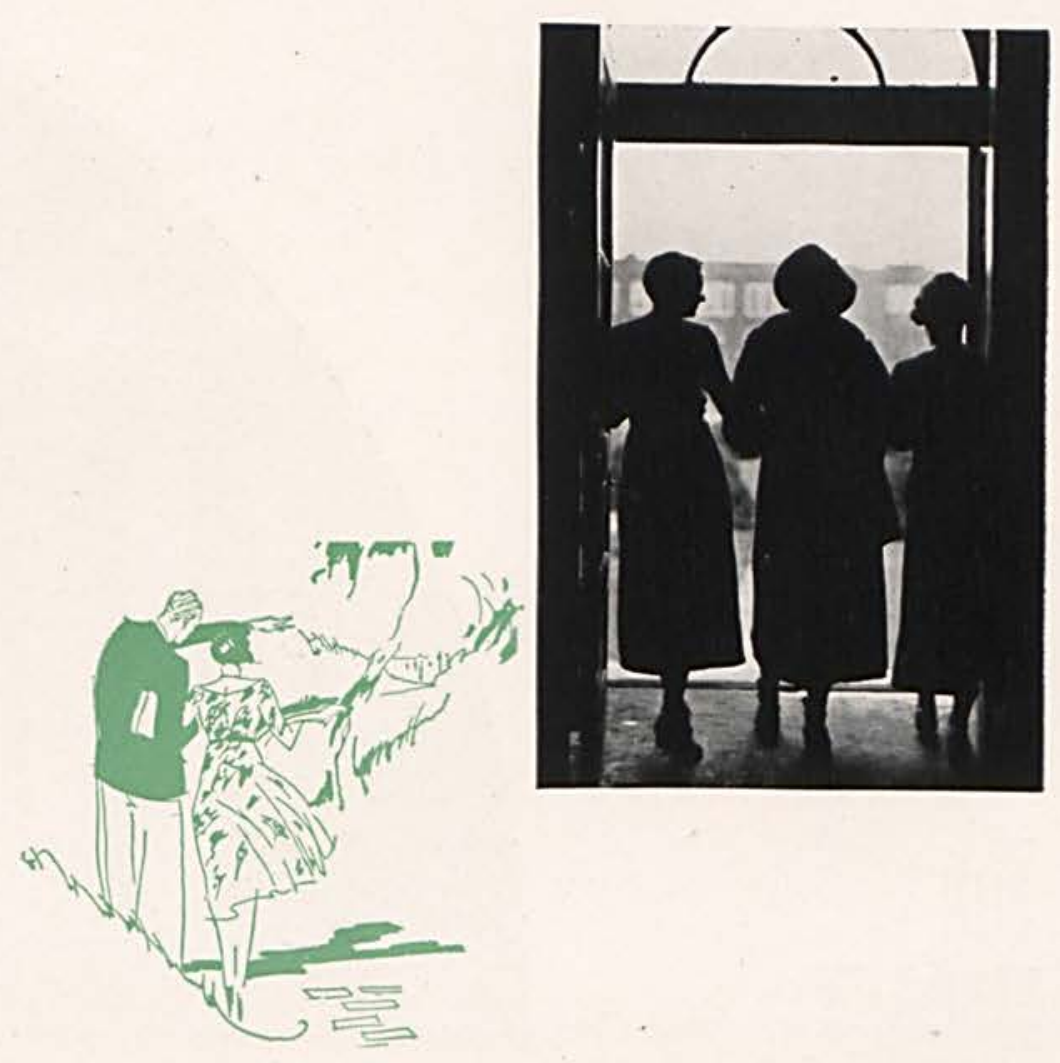


THE ADMINISTRATION

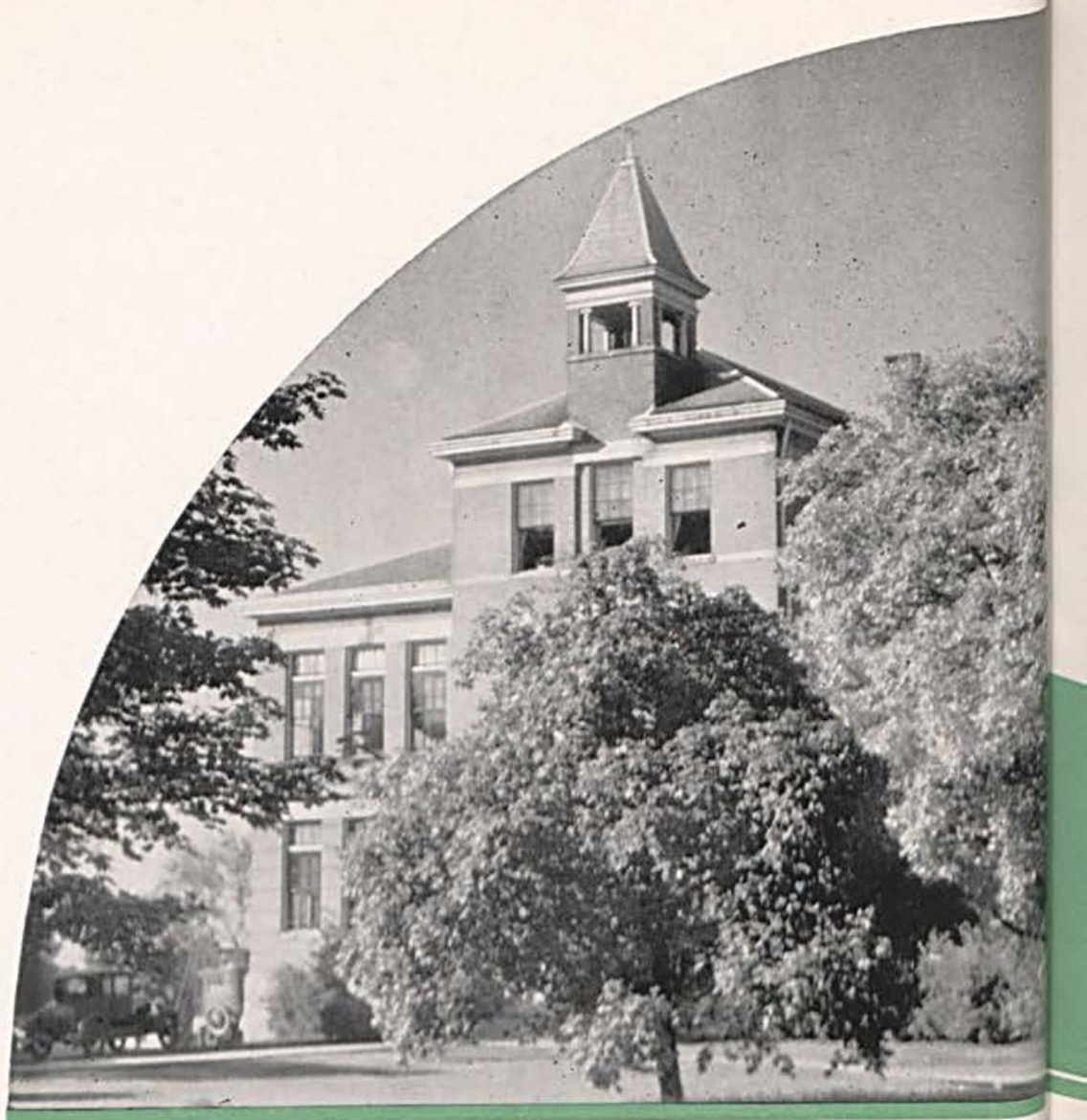

\section{THE \\ LIBRARY}

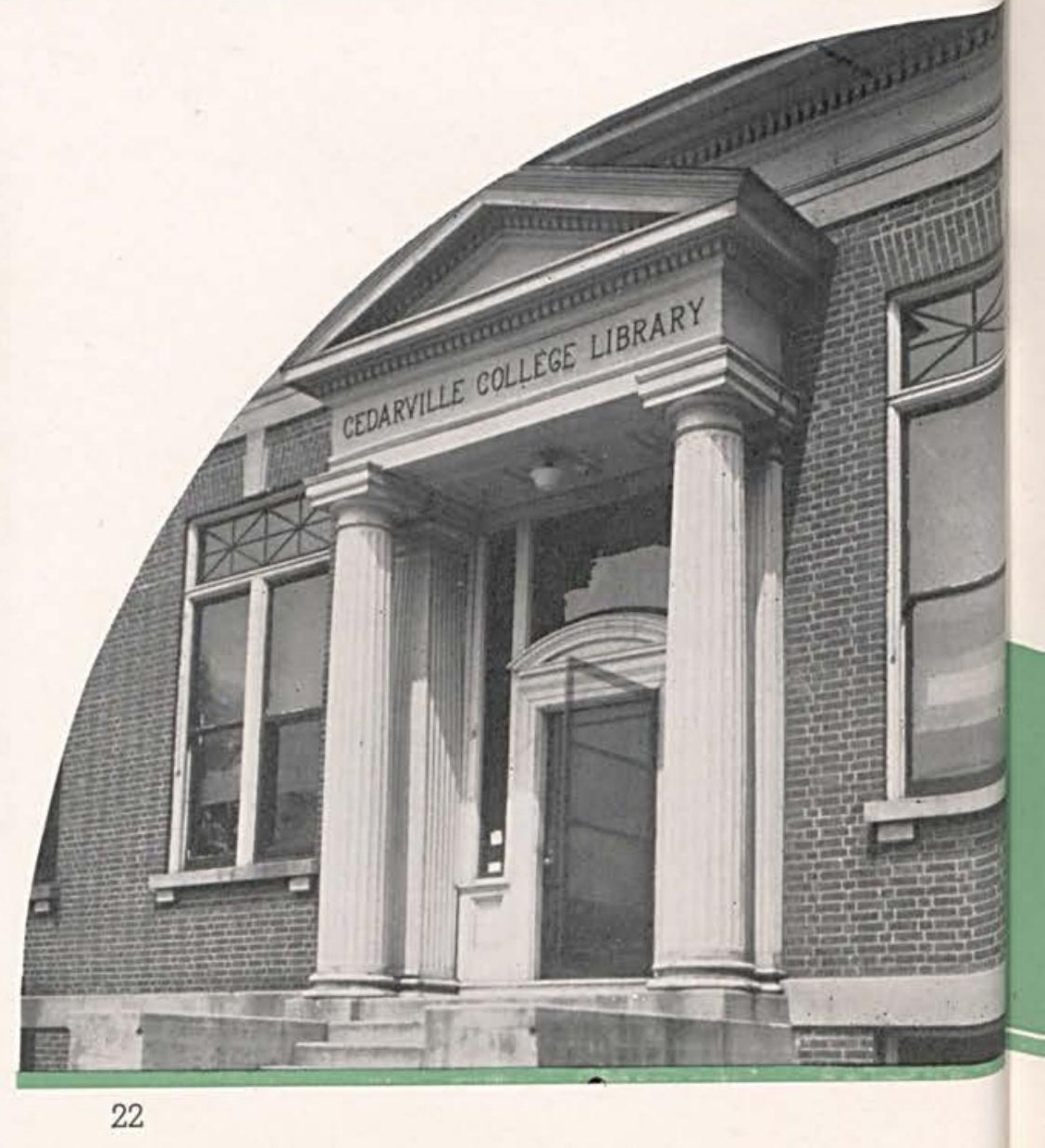


The Administration Building, "Old Main", is the oldest buldng on the original campus. Its ivy-covered walls have sheltered many students while they prepared themselves for the occupations in the world.

Cedarville College Library was built in 1905 from funds that were donated by Andrew Carnegie. Today the building houses both the village and the college libraries, the conservatory of music, the Seminary library, and the boarding club. 
THE GYMNASIUM

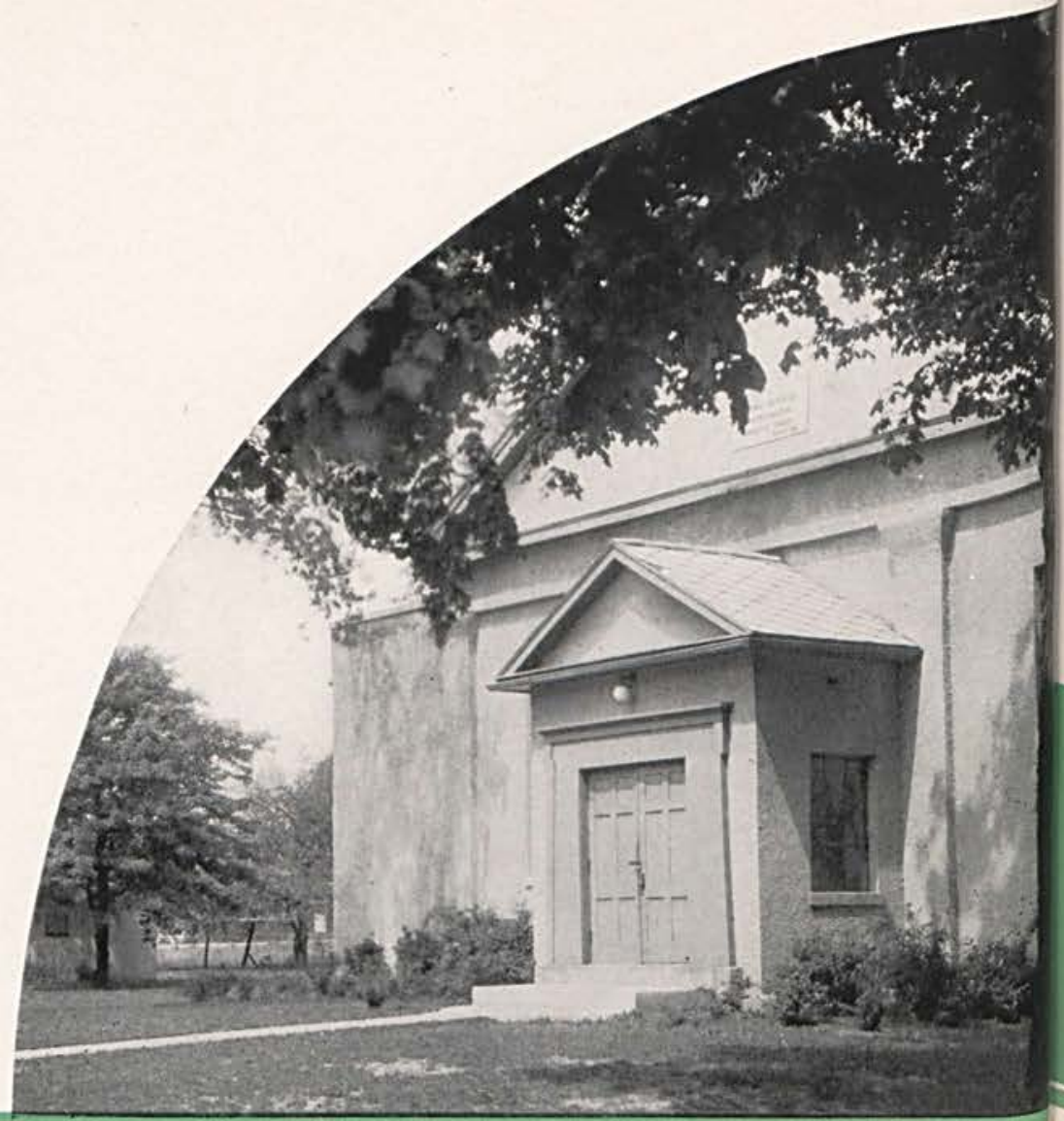

THE SCIENCE HALL

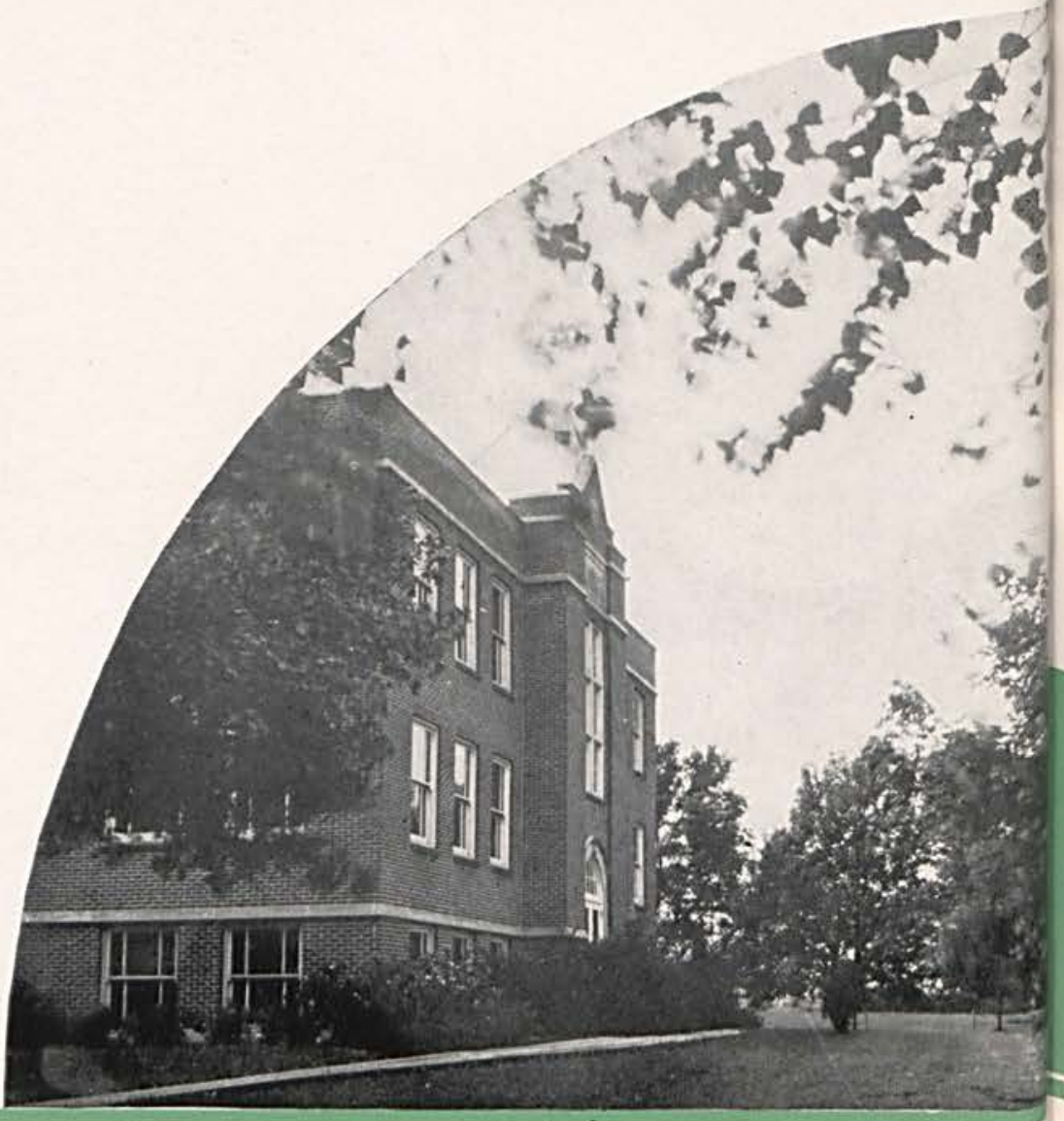


The Alford Memorial Gymnasium was at one time a Reformed Presbyterian Church. It was later bought and given to the College for a gymnasium in memory of Mr. Alford. It is the center of athletic activities.

The Science Hall is the newest building on the campus. For the person knowing nothing of science, her rooms are filled with queer apparatus, but it plays important parts in the lives of many students. 


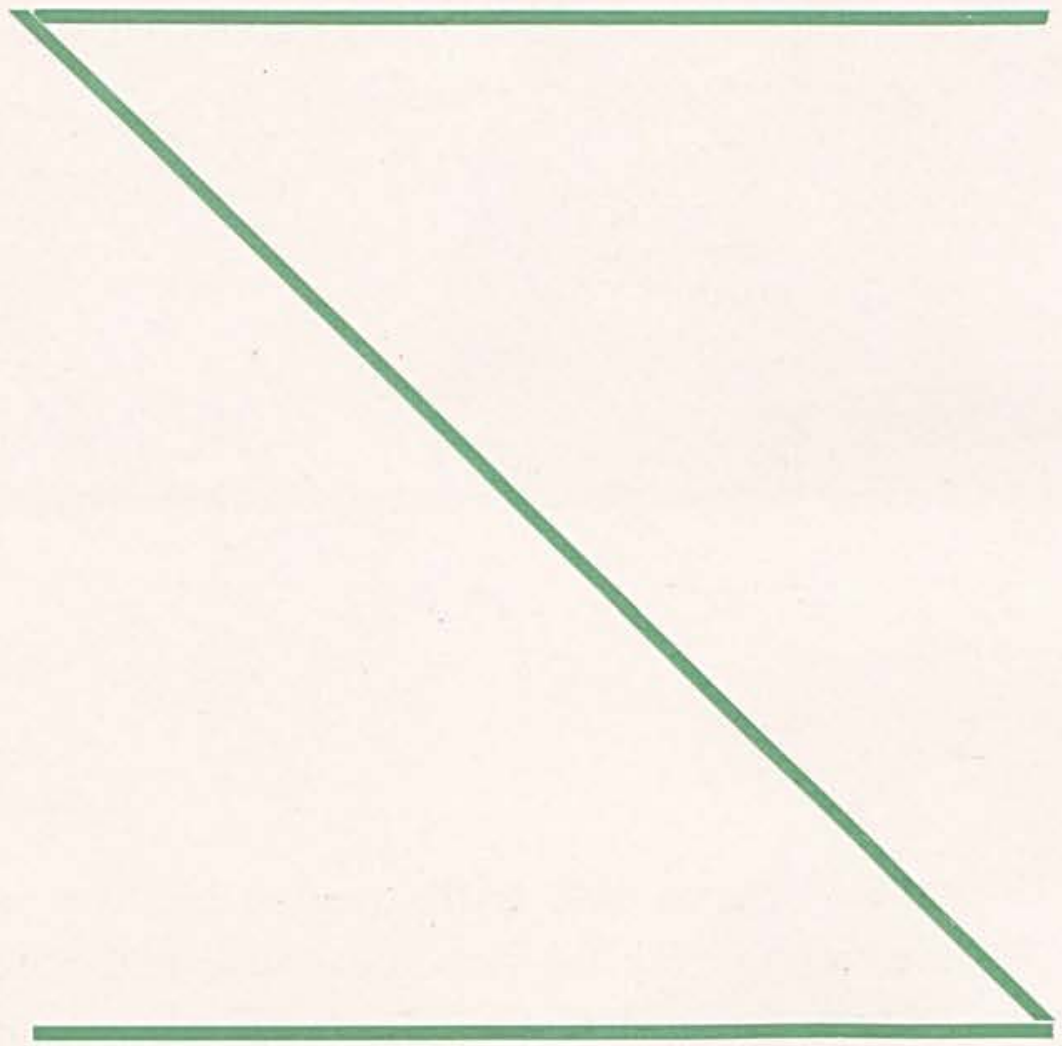


Book Two

THE PEOPLE 

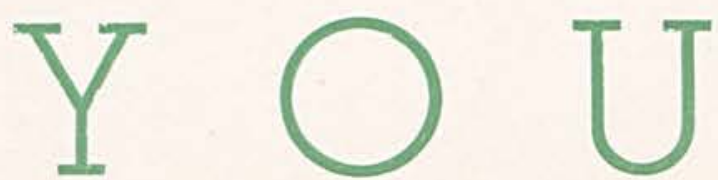

A 

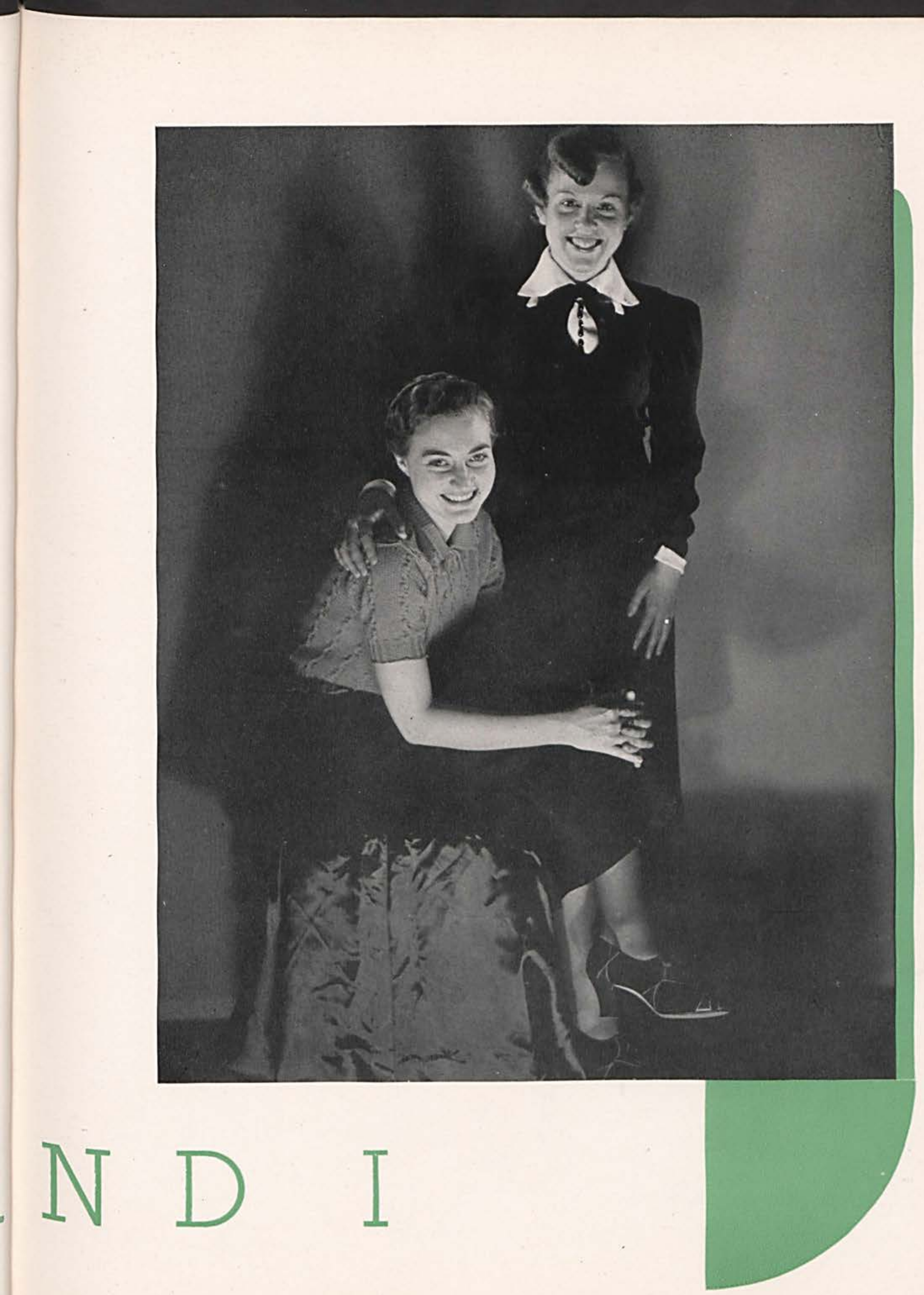


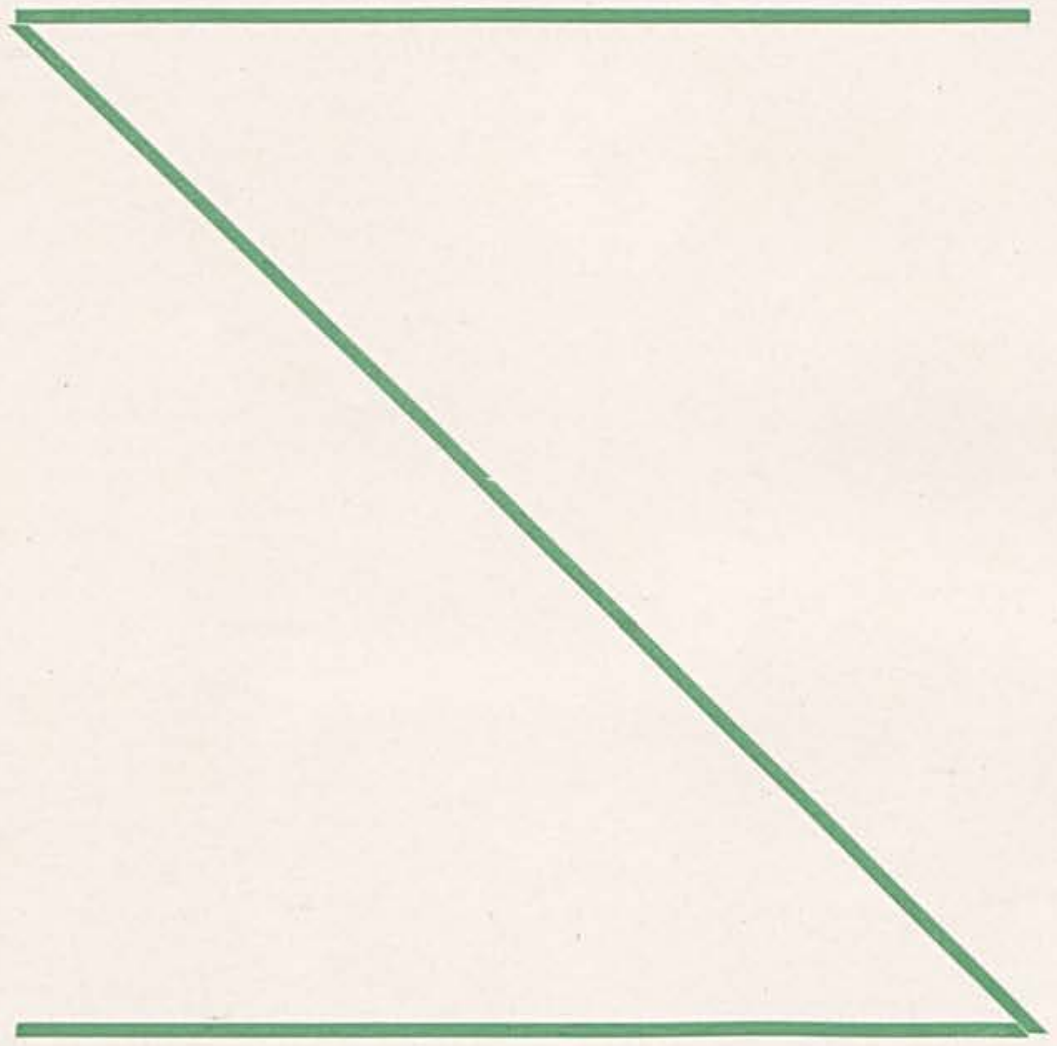




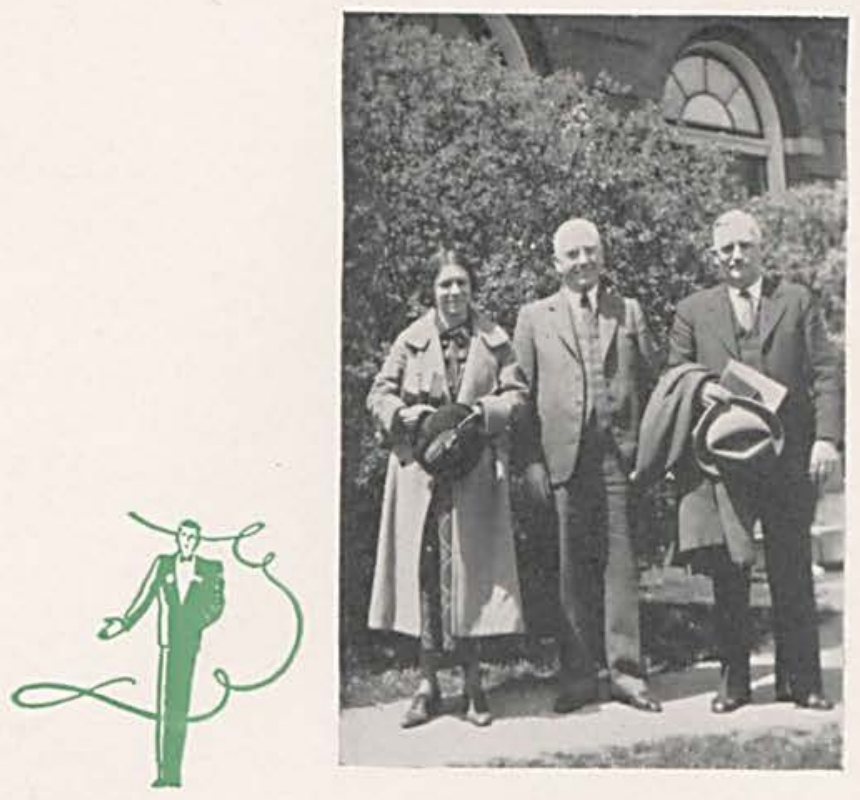

Administration 


\section{Trustees}

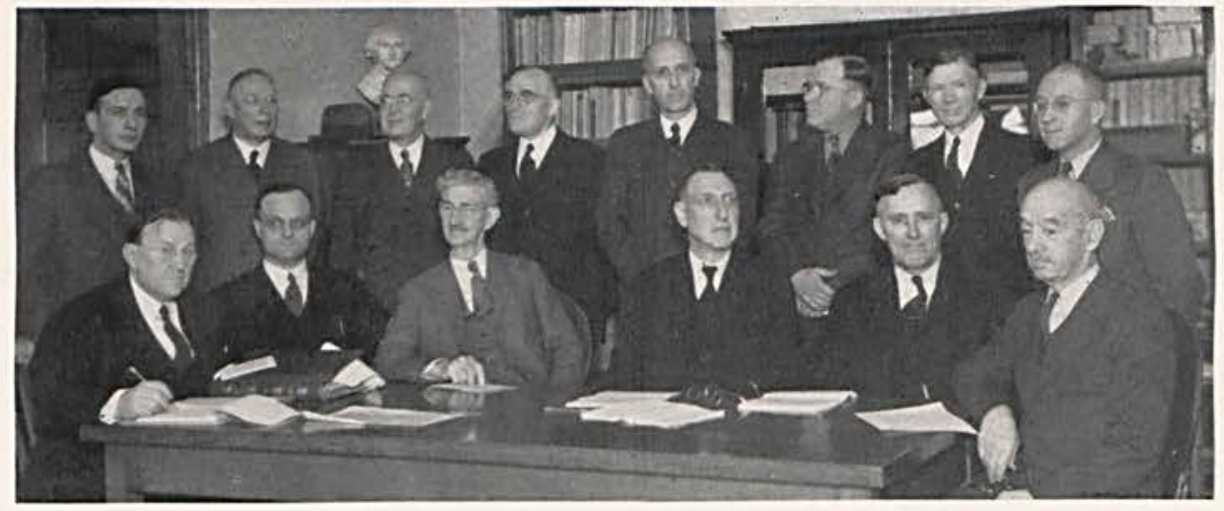

WM. H. TILFORD

WM. R. COLLINS

DR. M. I. MARSH

FRANK A. JURKAT

GEORGE T. HARTMAN

WM. CONLEY
PAUL ANGELL

W. R. MCCHESNEY

W. P. HARRIMAN

DR. W. R. GRAHAM

FRANK CRESWELL

WALTER ILIFF

J. LLOYD CONFARR 


\section{Officers}

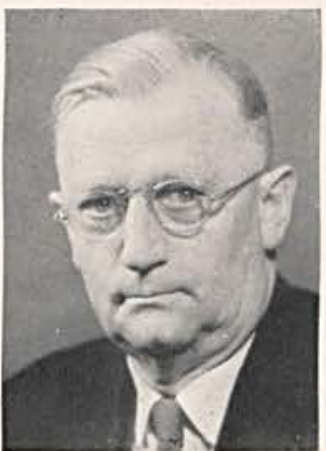

Dean of Men C. W. STEELE

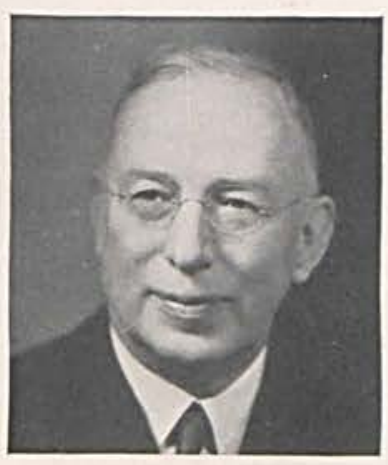

Business Manager JOHN DORST

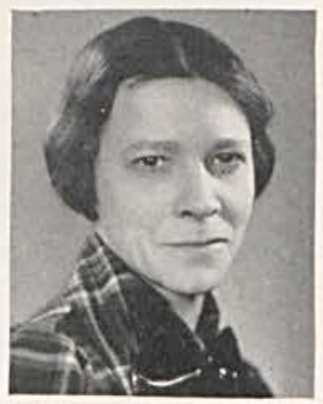

Dean of Women

H. H. SANTMYER

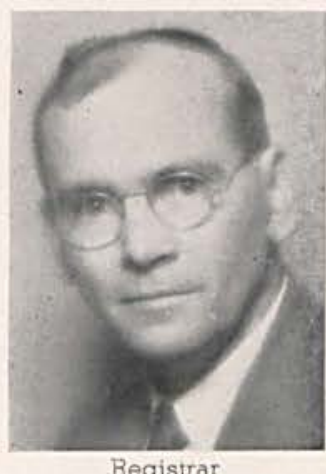

Registrar

A. J. HOSTETLER 


\section{Cedarville}

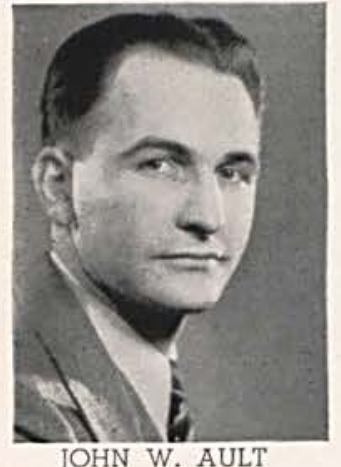

JOHN W. AUL

B.S., A.M.

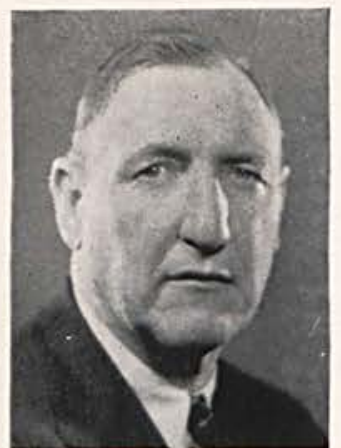

FRANK A. JURKAT A.B., L.L.D., A.M.

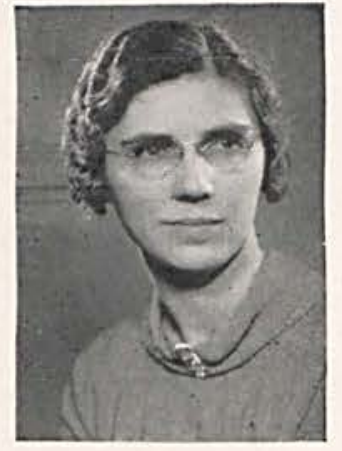

GLENNA BASORE B. Orat., A.B.
Every student of Cedarville will testify that a finer faculty cannot be found. Each member is willing to help students by individual work.

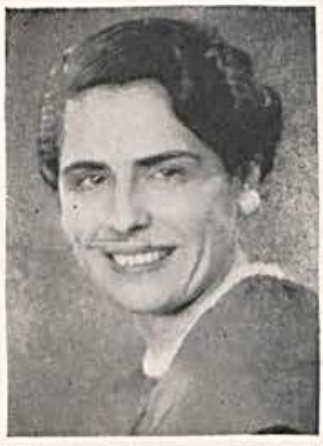

MARGUERITE AULT B.S. in Ed. 


\section{Faculty}

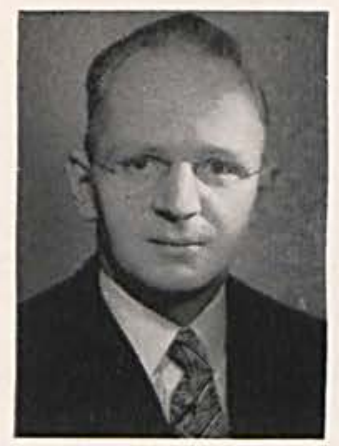

DWIGHT R. GUTHRIE

B.A., St.B., Ph.D.
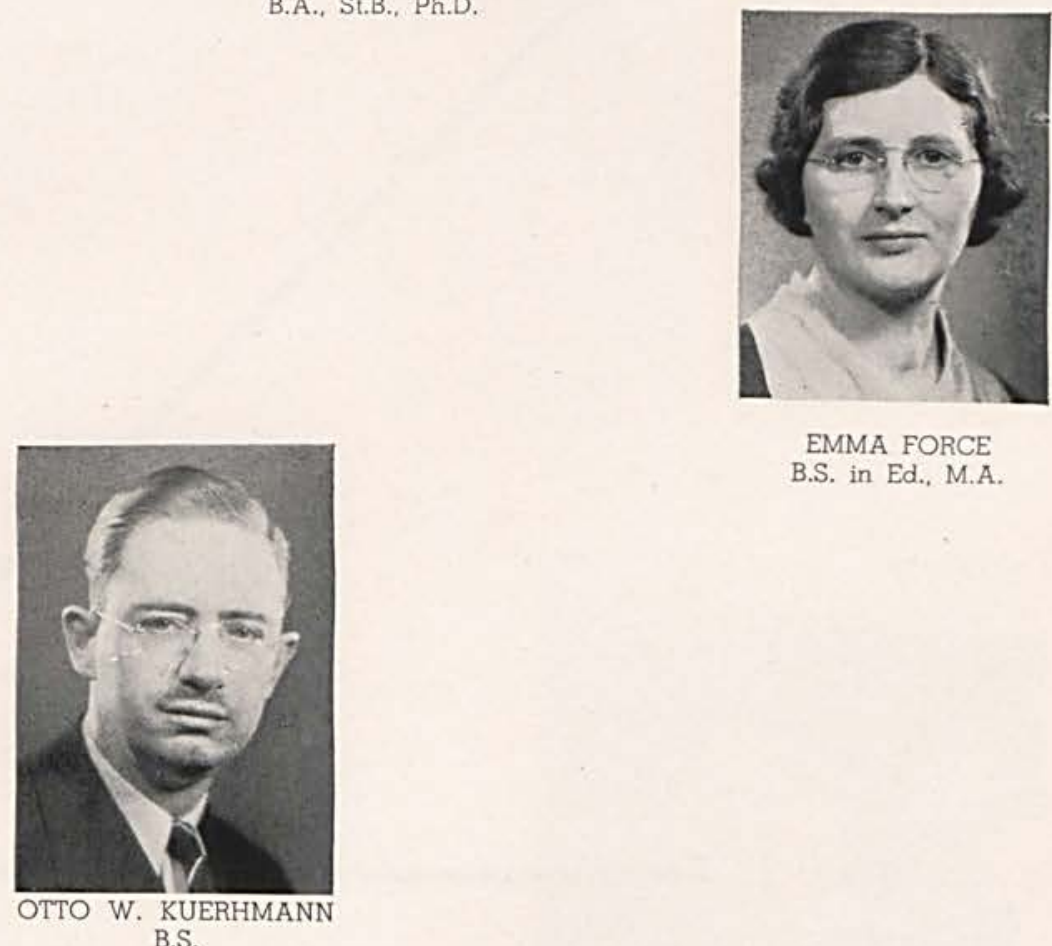

EMMA FORCE

B.S. in Ed., M.A.
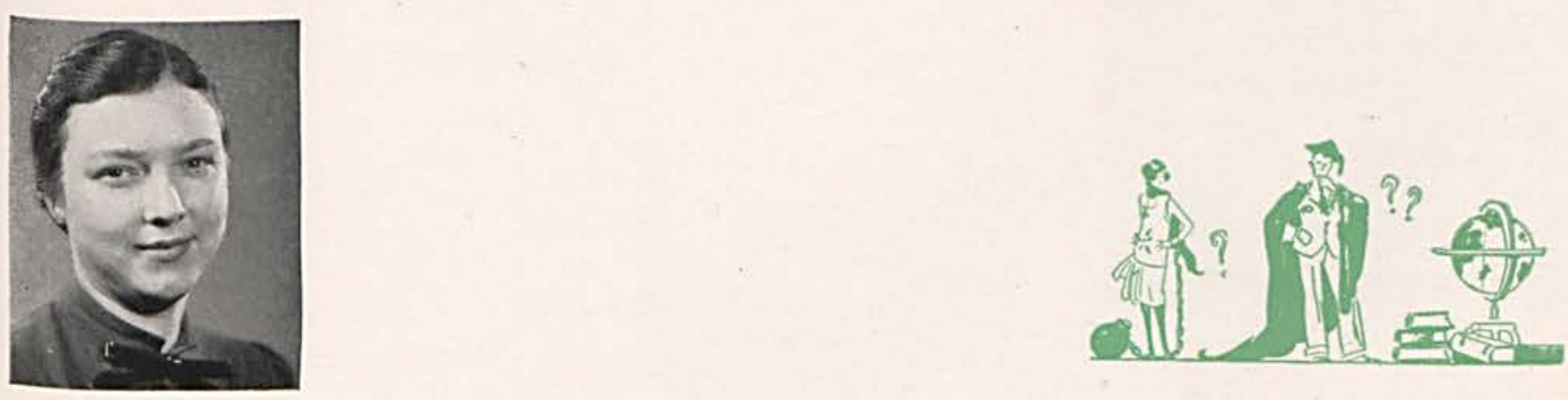

MILDRED BICKETT

A.B., Mus. B. 


$$
\nabla
$$




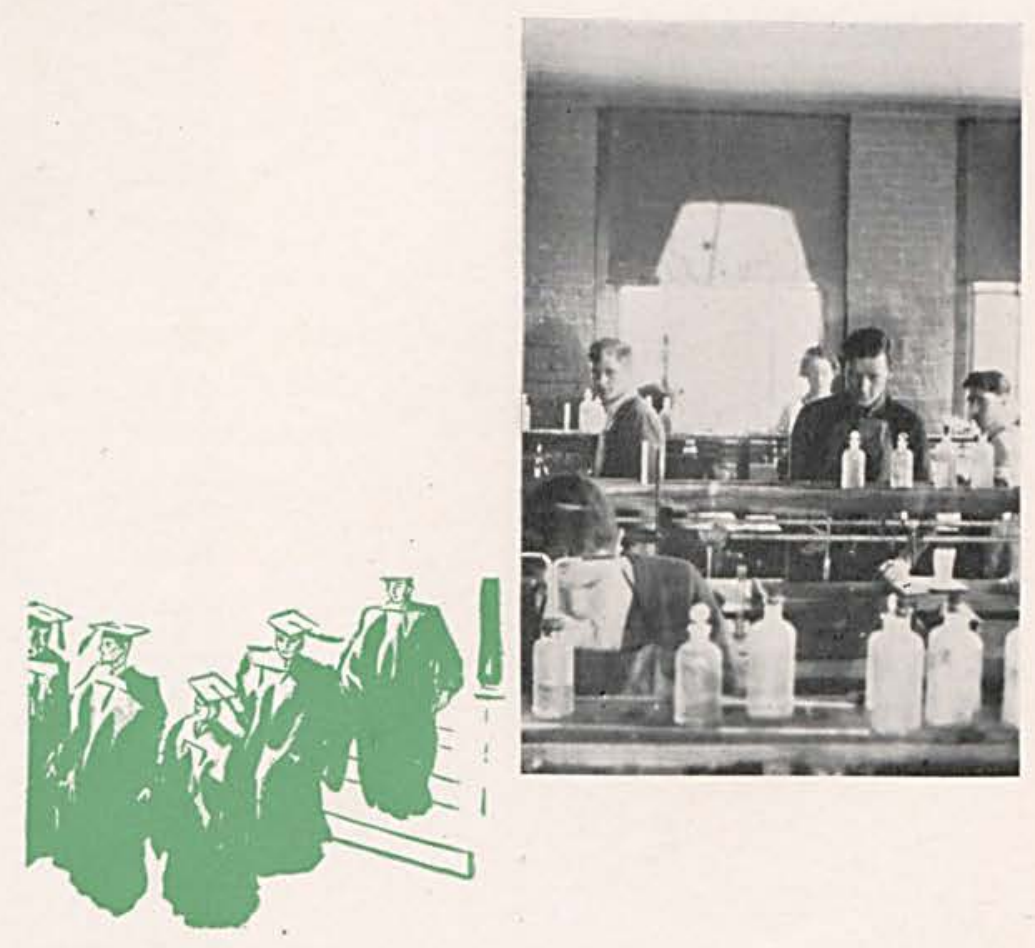




\section{Tresthmem}

\section{FRESHMAN CLASS HISTORY}

The freshmen survived initiation week only to be disgraced by the upper classmen at the annual tugof-war at Willow Bend. We still claim that the upper classmen used that rotten rope for a purpose. Since that first "feed" at which many unbidden guests helped roast the wieners, we have thoroughly enjoyed many peaceful parties due to the new ruling that forbids the upper classmen to break up freshman feeds!

Coach Ault will have many places to fill on his teams next year (which were vacated by graduating members) so we freshmen are hoping that some of our skilled athletes will have a chance to make a good showing.

In addition to our contribution to athletics, we have two members singing with the "Harmonizers" and one touring with the Gospel Team.

We are looking forward to another happy year at Cedarville.

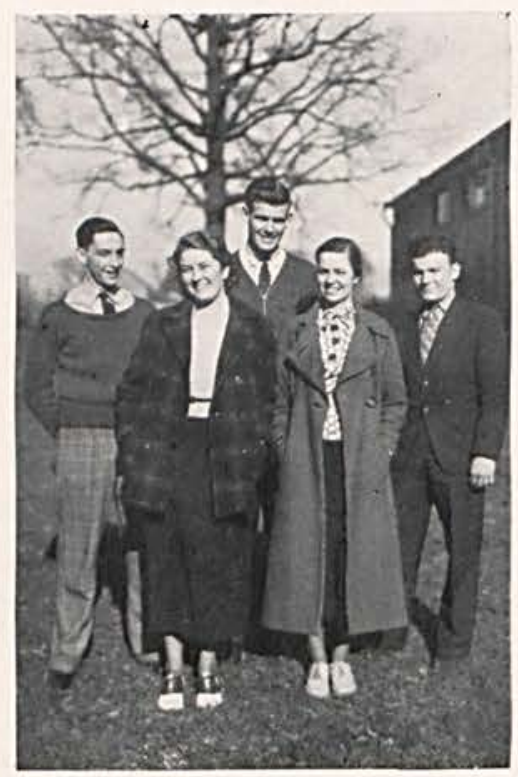

JOHN PETERSON, Treasurer

GENEVA CLEMANS, Secretary

GENEVIEVE JESSON, Reporter

ELDON GILLESPIE, President

RUSSELL ROBERTS, Vice-President 


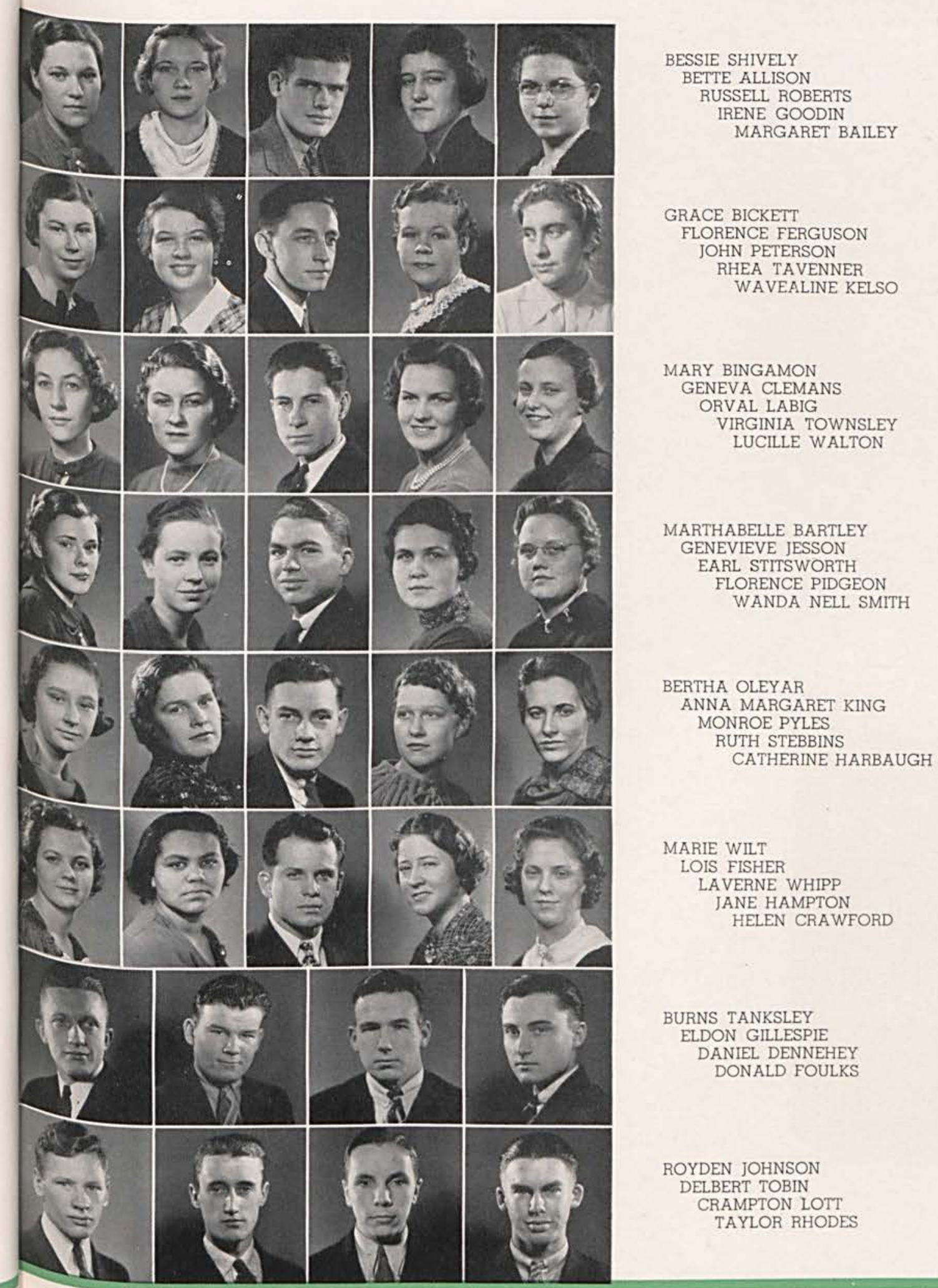




\section{Sonthanmares}

ELDON FOULK

ESTHER SHUMP

MARJORIE GRAVES ROLLAND FLORY

WILMA GRIMES

CHRISTINE TOBIAS JOHN FOX

RAYMOND SISSON MARY HOLWAY

On September 10, 1935, the largest class in the history of the college embarked on the first voyage of their college career.

The first few weeks were rather rough sailing, but under the direction of our captain and mates, Frederick Heifner, Roy Linton, Cletis Jacobs and Richard Smith, we weighed anchor in our first harbor without disaster.

The following September we began the second lap of our journey, the end of which will be the destination for a number of us.

During these two years our crew has been active in all phases of college activities - music, athletics, dramatics and debate.

To those who are leaving - success. To those remaining - Bon Voyage.

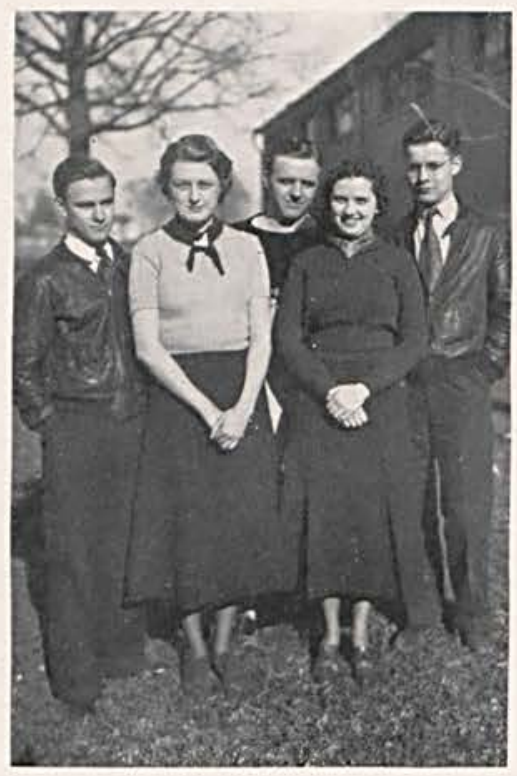

RAYMOND SISSON, President

ESTHER SHUMP

Treasurer

MARGARET NELSON Secretary

FRED LOTT Reporter

ROY LINTON Vice-President
KENNETH MCNEAL EURYDICE COLLINS PAULINE LONG ANGUS MURRAY ELIZABETH RICHARDS CLETIS JACOBS CLYDE WALKER

LEWIS PRESCOTT

FRANCES KIMBLE

LEE SPAHR

FRED LOTT ELEANOR COOLEY GRETCHEN TINDALL VICTOR SHAW

JANE FRAME

TEAN KENDIG

EARL ALLISON

\section{FRED HEIFNER DORIS WATKINS BEATRICE MCCLELLAN JAMES JACKSON EVELYN TIPTON \\ MARGARET NELSON CHARLES FORD}

MELVIN THOMPSON JULIA HOLLAND ELINOR GIBSON BLUTCHER GIBSON HELEN SEAMON MARY PIERCE WILFRED MacDONALD

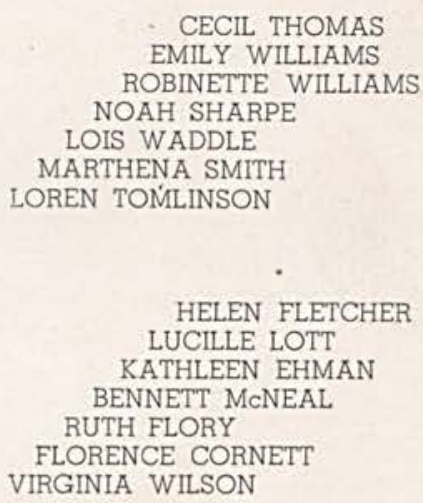

CECIL THOMAS EMILY WILLIAMS ROBINETTE WILLIAMS NOAH SHARPE LOIS WADDLE

MARTHENA SMITH LOREN TOMLINSON

HELEN FLETCHER

LUCILLE LOTT KATHLEEN EHMAN BENNETT MCNEAL RUTH FLORY FLORENCE CORNETT VIRGINIA WILSON 


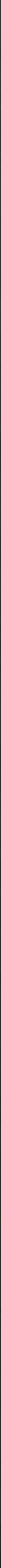




\section{Junious}
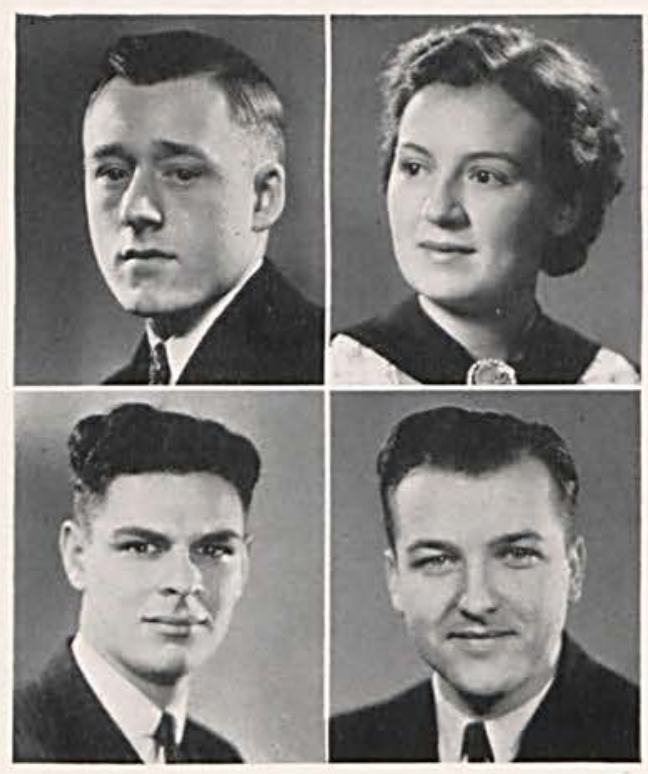

This is Station J U N I O R broadcasting from Cedarville College, the history and traditions of this class. Your announcer is the spirit of the Junior class bringing to you the close of the third year of this broadcast.

We are proud of the first year of our program although there was static at times - freshmen initiation and parties broken up by upper classmen. In spite of these air disturbances, however, we had many good times that still linger in our minds, namely the atrocities of freshmen week and the house-wrecking at Anderson's. Our director the first year was James Anderson who brought us on and off the air at just the right moments. In June of 1935, we signed off, a wiser and older group having contributed much to student activities at Cedarville College.

We did not stay signed off for long, for in September we came back, ready to go on the air once more. John Gillespie was chosen as our director that year and our broadcast proceeded without a flaw. We made ourselves felt in athletics, dramatics, music, debate, scholarship, and other college activities. Many of our members left us at the close of that year, and we have truly missed them.

KENNETH SANDERSON President

JAMES ANDERSON

Secretary-Treasurer
MARY JOHNSON

Vice-President

\section{EUGENE REED \\ Reporter}


Our third year has been the climax of our broadcast. Kenneth Sanderson has ably directed our activities during the past year. The high spots of this memorable part of our program were the Junior play "Yours Truly Willie", and the Junior-Senior Banquet. The play was a "howling" success, most of it being done by little Willie, Roy Linton. The "moonlight" banquet was held at the Dayton Y. M. C. A. on May 13 with a theatre party afterward.

Now Station JUNIORS is signing off; happy and pleased with the past years; anticipating what the future in Cedarville College holds for us; wishing you all as successful a career as ours has been.
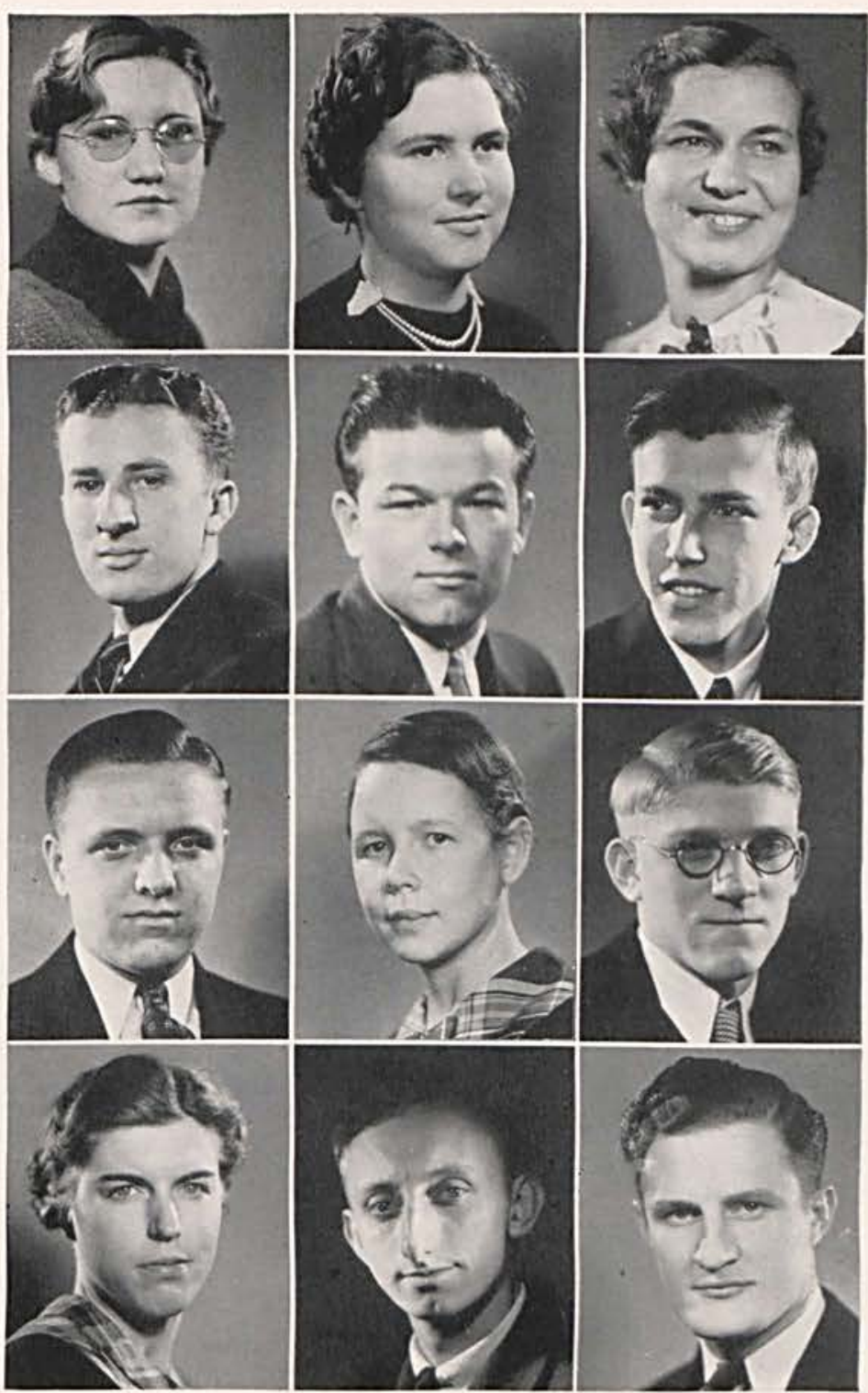

IRENE ALLISON

HERBERT CUMMINGS

ROY LINTON

BETTY SHAW

\section{MARTHA BRYANT \\ IOHN GILLESPIE \\ MILDRED MCKIBBEN \\ HARRY SINKS}

RACHEL CRESWELL
JUSTIN HARTMAN
HAROLD SHAW

HAROLD SHAW 


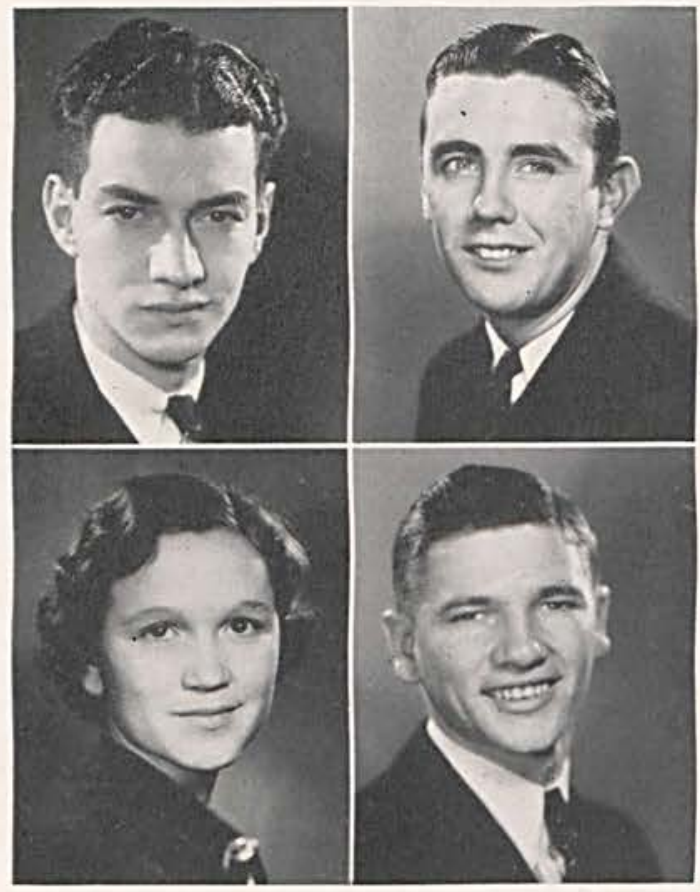

\section{Graduates of}

JOHN TOBIAS

President

RUTH KIMBLE

Secretary
HARRY WALLACE

Vice-President

GALE ROSS

Treasurer

\section{SENIOR CLASS HISTORY}

Four years ago forty freshmen entered Cedarville College. During the first month of school, we made our presence felt by pulling the upper classmen into Willow Bend - a most unusual proceeding - and by successfully thwarting attempts at breaking up our feeds. During this year we contributed six members to basketball and baseball, one to debate, three to the girls' quartette, and three to the Gospel Team.

Our second year was a continuation of the fun, study, and success of the first.

Our third year found our number greatly reduced to fifteen. The two high spots of this year were the class play "Forever True" and the Junior-Senior Banquet which was held in the Y. M. C. A. in Dayton. 


\section{THIRTY SEVEN}

DOROTHY ANDERSON MARY HELEN CRESWELI JOHN RICHARDS

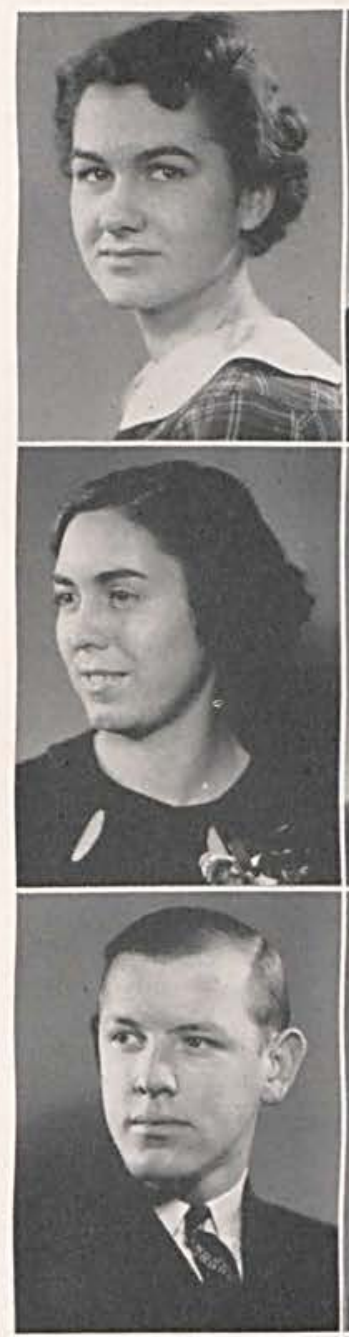

This year has been filled with activity for every one of our members. We are proud of the record which we have made. We are proud of the spirit of comaraderie which has existed in our class during its entire history; it is our boast that we have never had a disagreement. Our last appearance as a class will be in the class play "The Cat and the Canary" which will be given on June 1 . We are sorry to leave but we are giad that we have been in Ceaar. ville College - together. PETTY FISHER ROBERT THOMPSON JOSEPH WADDLE
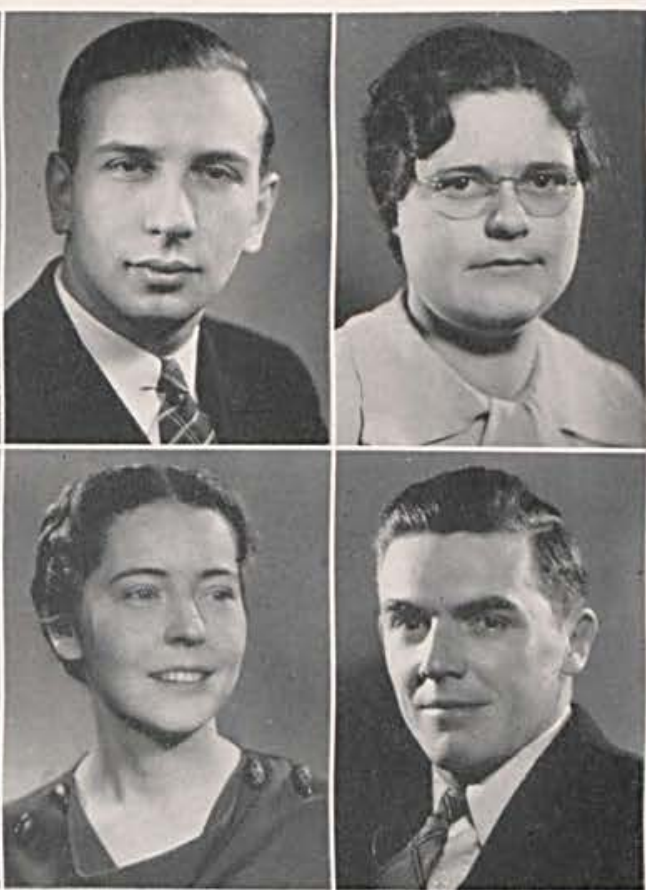

MILDRED BEARD

ALBERT GRUBBE

ESTHER WADDLE
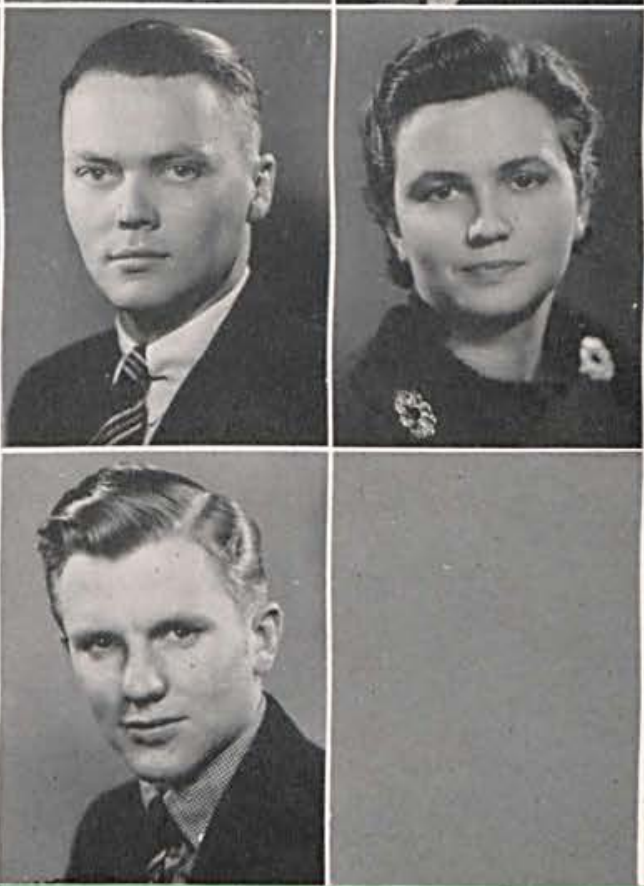


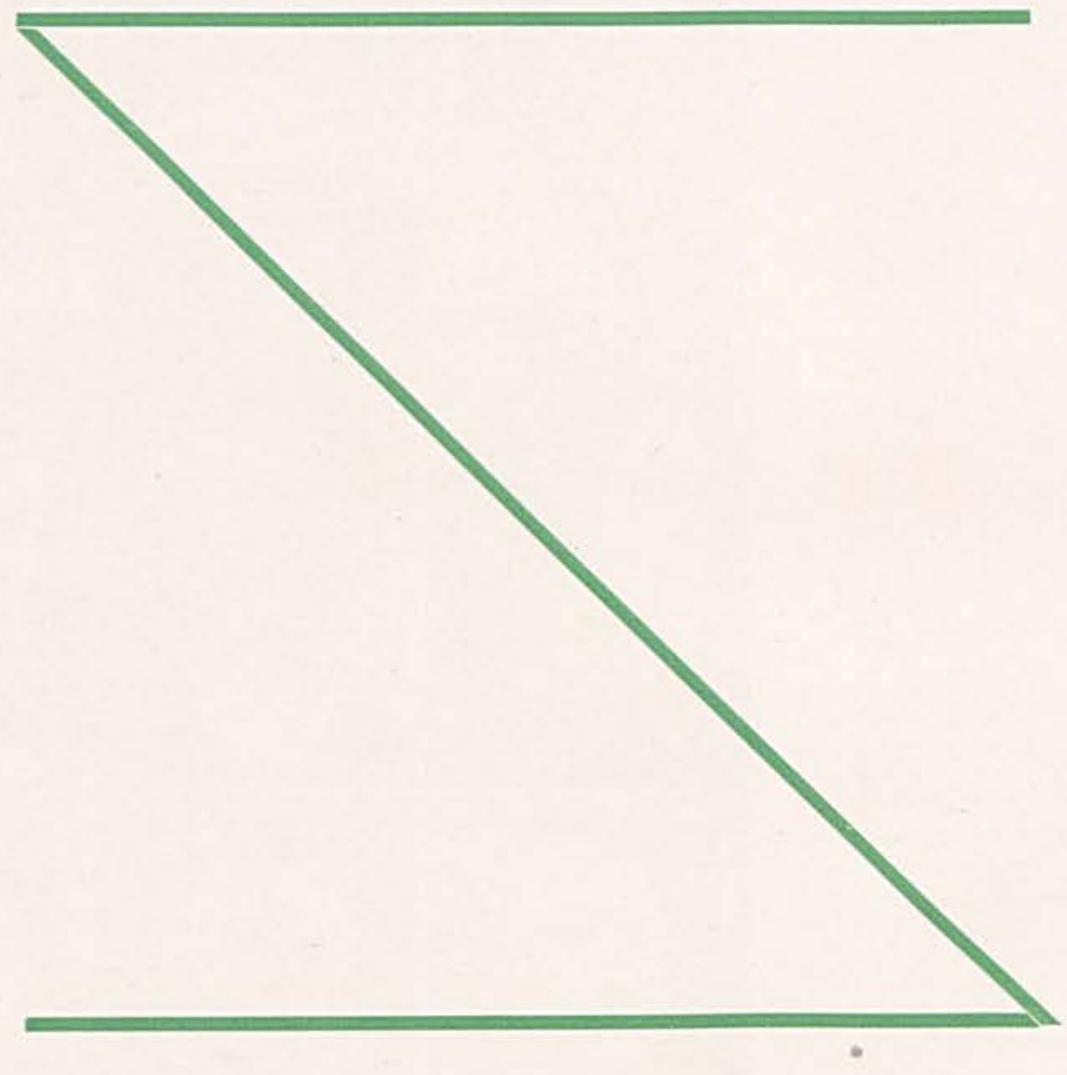


Book Three

E V E N T S 


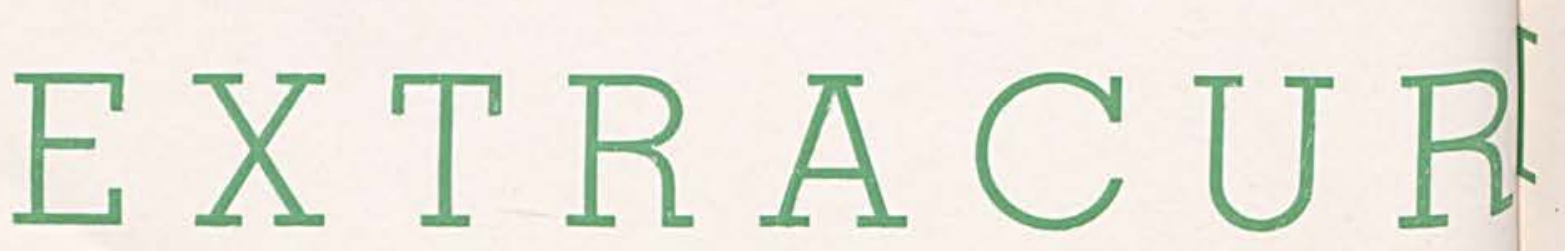




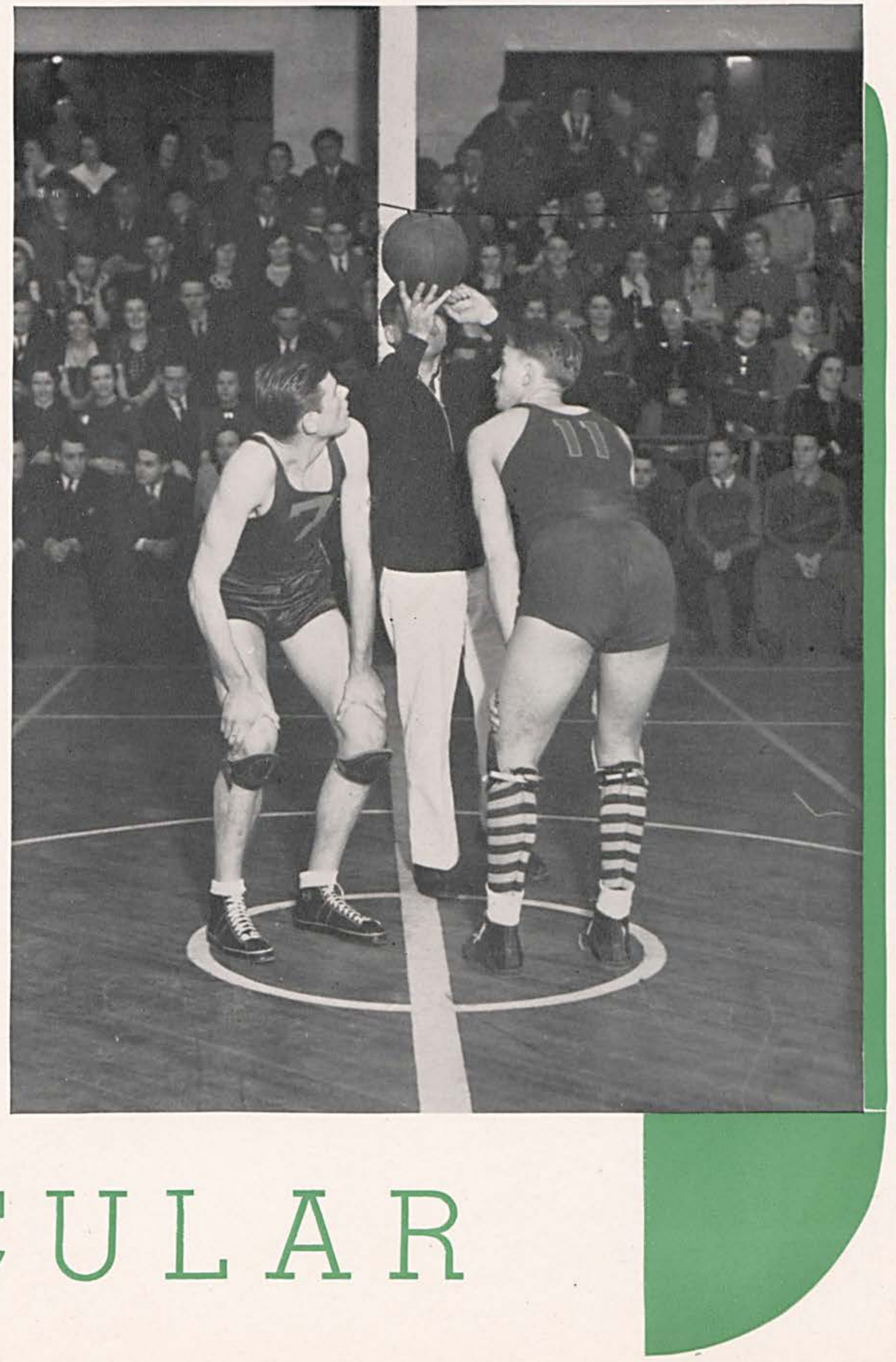




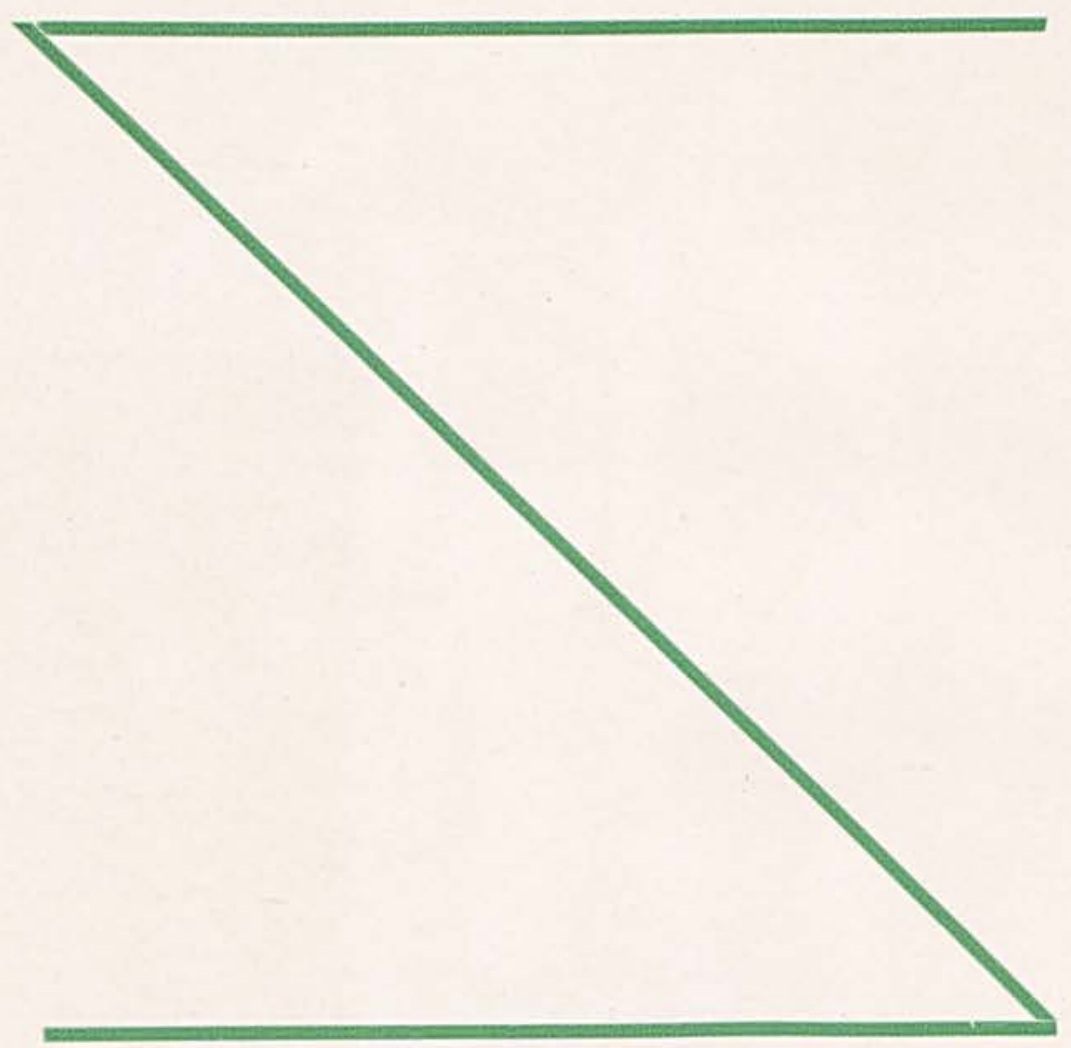



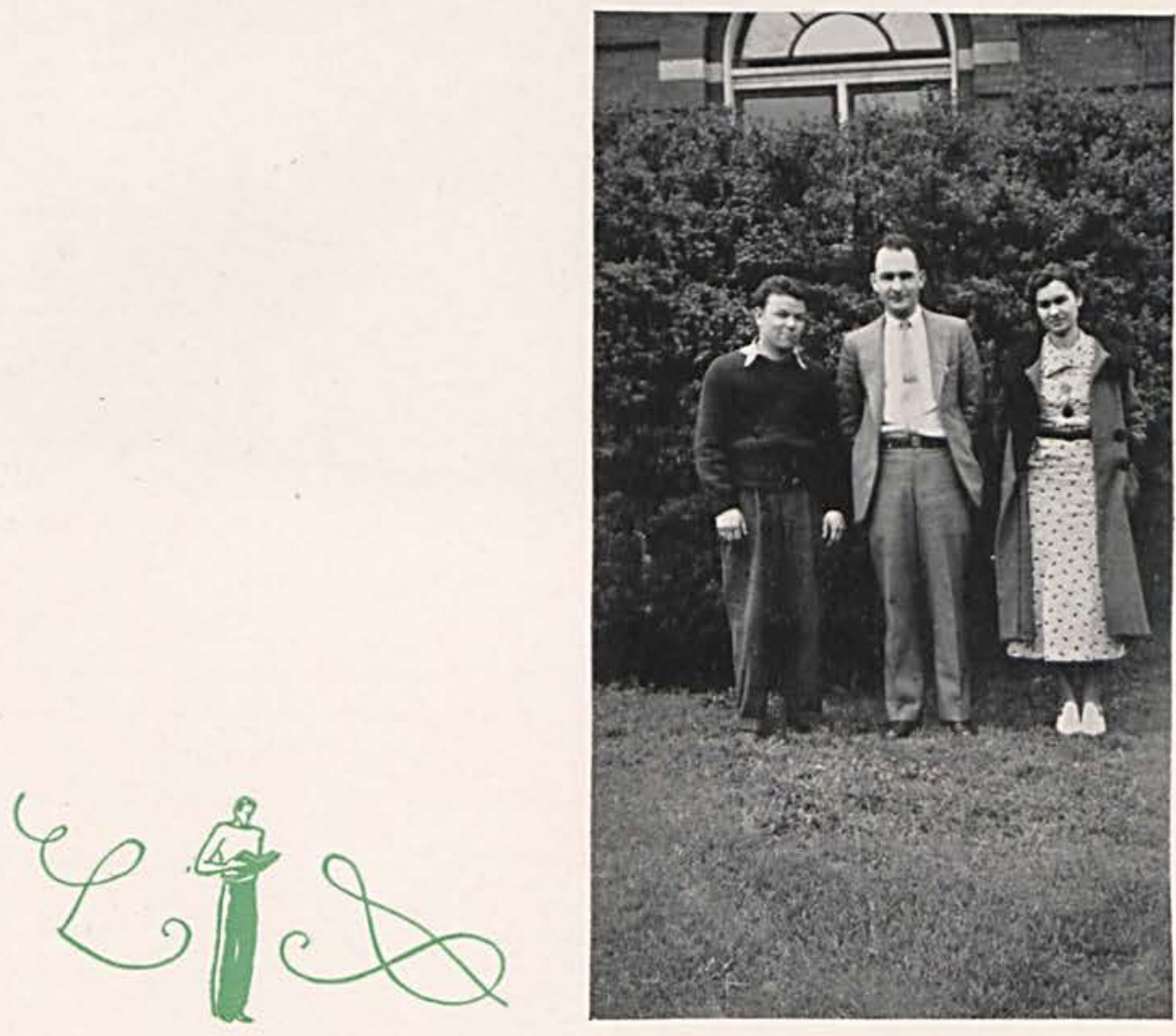


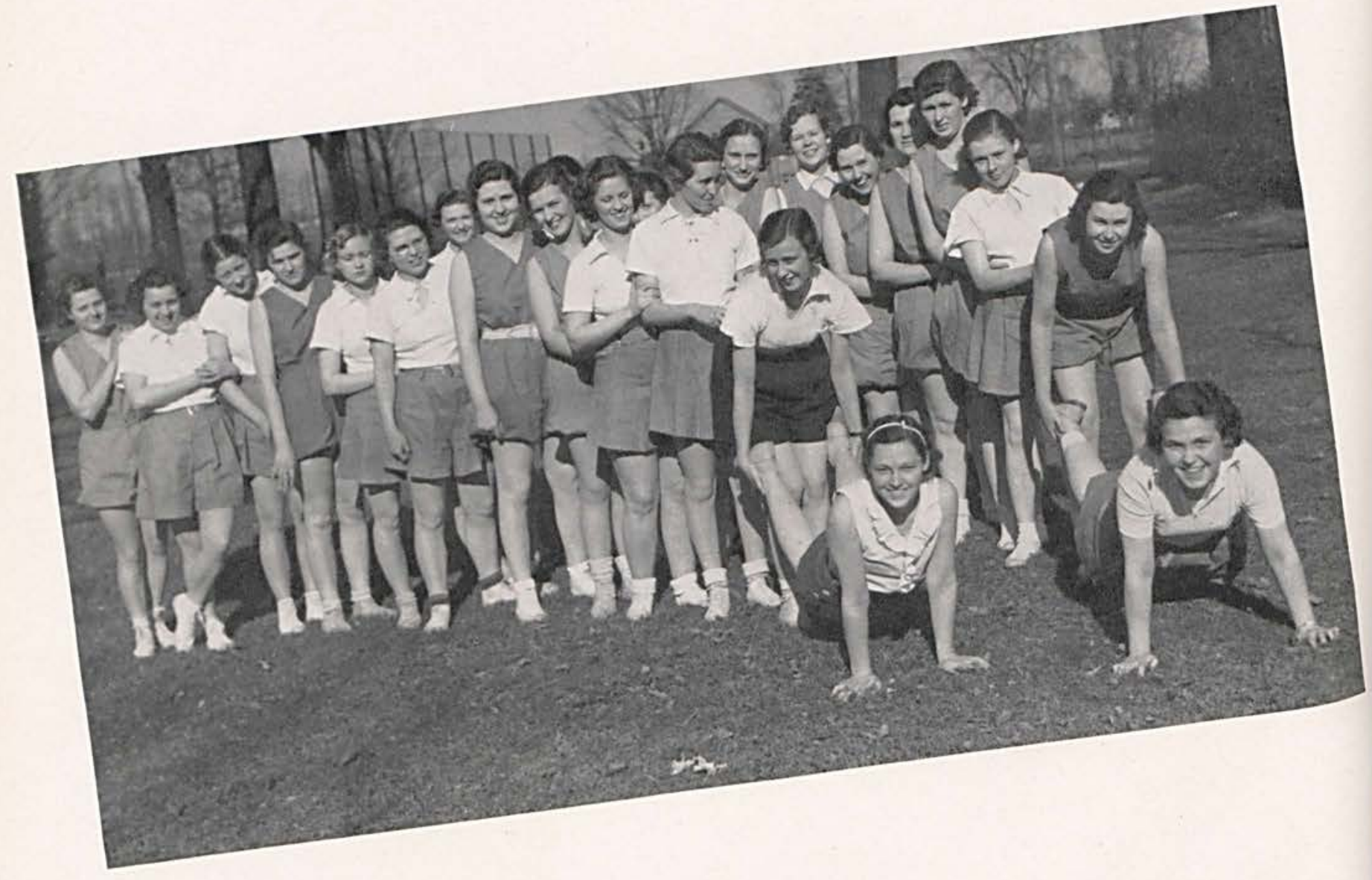

Physical Education

CEDARILLE 


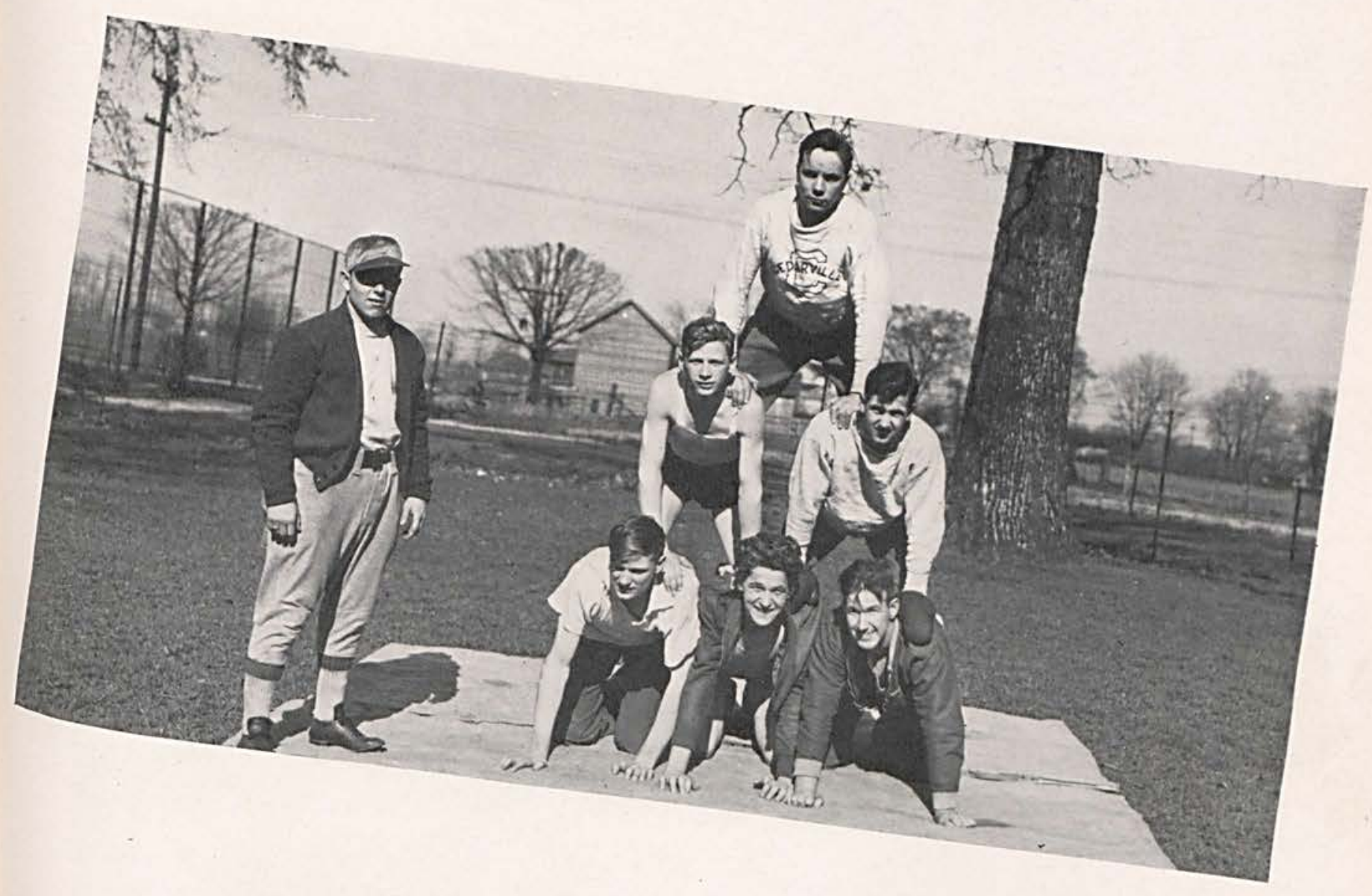

Physical Education 


\section{Baskettladl}

$\mathrm{COACH}$ J. W. AULT

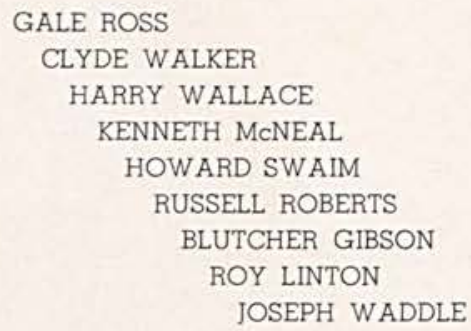

CLYDE WALKER

HARRY WALLACE

KENNETH MCNEAL

HOWARD SWAIM

RUSSELL ROBERTS

BLUTCHER GIBSON

ROY LINTON

JOSEPH WADDLE

\section{DONALD FAULKS \\ LAVERNE WHIPP \\ CECIL THOMAS \\ ELDEN FOULK \\ WILFRED MCDONALD \\ EUGENE REED \\ ELDEN GILLESPIE}

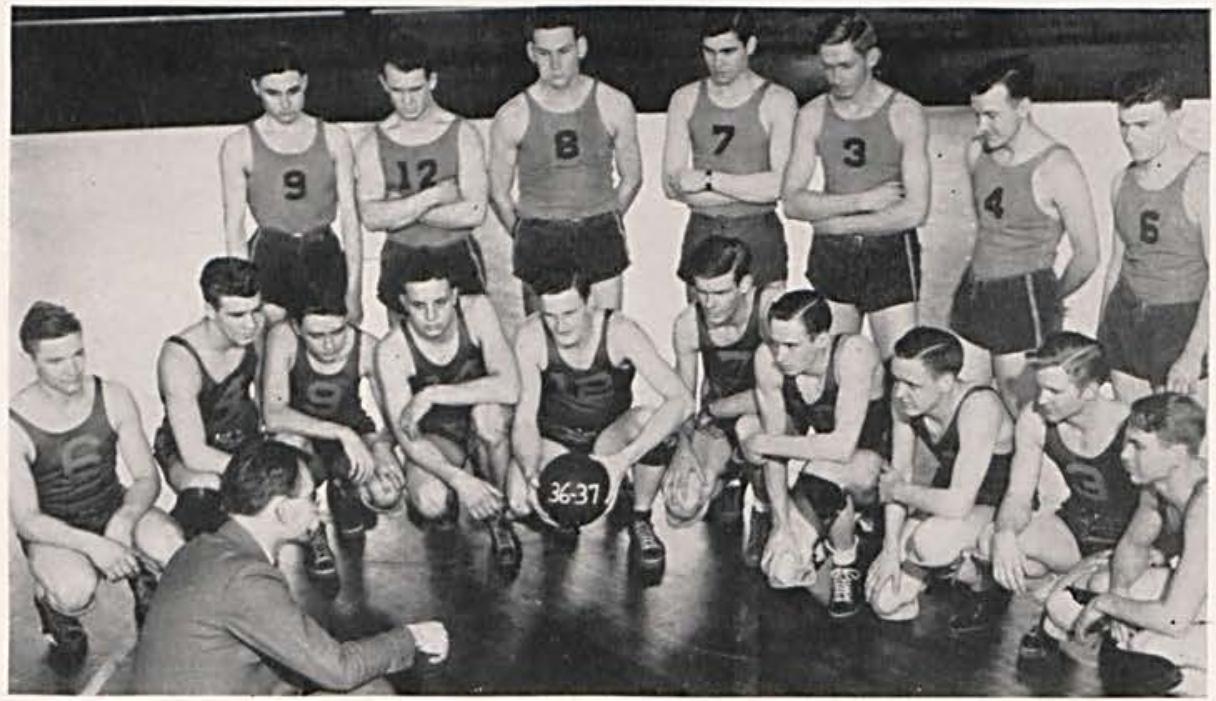




\section{SCHEDULE AND RESULTS}

\begin{tabular}{lrllll} 
Date & \multicolumn{1}{l}{ Winner } \\
December & 4 & Cedarville & 40 & vs. & 21 \\
December & 12 & Otterbein & 39 & vs. & 28 \\
December & 15 & Cedarville & 42 & vs. & 29 \\
January & 14 & Cedarville & 33 & vs. & 19 \\
January & 22 & Cedarville & 45 & vs. & 28 \\
January & 26 & Cedarville & 33 & vs. & 25 \\
January & 30 & Cedarville & 39 & vs. & 19 \\
February & 2 & Wilmington & 24 & vs. & 13 \\
February & 6 & Rio Grande & 27 & vs. & 25 \\
February & 11 & Cedarville & 47 & vs. & 38 \\
February & 16 & Wilmington & 36 & vs. & 27 \\
February & 20 & Cedarville & 49 & vs. & 27
\end{tabular}

\section{Loser}

Y. M. C. A. at

Bluffton at

Cedarville at

Defiance at

Y. M. C. A. at

Rio Grande at

Franklin at

Cedarville at

at Cedarville (H.C.)

Defiance at

Cedarville at

Bluffton at
Where?

Cedarville

Cedarville

Otterbein

Defiance

Springfield

Rio Grande

Cedarville

Wilmington

Cedarville

Cedarville

Bluffton

For the second year in succession the Cedarville College basketball team has had a successful season. Out of a total of ten games played, our boys were able to capture eight, making the very satisfactory record for the season read: Won 8 , Lost 4 .

The team and student body showed a wonderful spirit through the whole season which contributed a great deal toward winning as many games as we did. Furthermore several Freshman recruits added a great deal of strength to the squad. And as a result the team played some great basketball, tied with Wilmington for the Conference championship.

The team will lose three of its regulars by the route of graduation which will probably weaken the team slightly. But with Swaim and Linton as a nucleus we are all confident that Coach Ault and his boys will bring us another winner in 1938. Those lost by graduation are as follows: Waddle, Wallace and Gibson. We all hate to see these boys leave us and would like to take this opportunity to show our appreciation to their fighting spirit and good sportsmanship. Below is a bit from the "Whispering Cedars" describing the graduating members.

... Waddle isn't very big, but neither is dynamite. (Captain)

.... Wallace can be named as one of the finest guards to be seen on any basketball floor.

... Gibson 's accurate passing and fine eye will always be remembered by all students.

Letters were awarded to Wallace, Waddle, Gibson, Swaim, Linton, Roberts, Walker and "Ken" McNeal. 


\section{Baseleall}

CRAMTON LOTT

DONALD FOULKS

RAYMOND SISSON

ELDEN GILLESPIE

COACH J. W. AULT

JOHN GILLESPIE

LAVERNE WHIPP

MELVIN THOMPSON

HARRY WALLACE

HAROLD BAYNARD

CECIL THOMAS

RUSSELL ROBERTS

JAMES JACKSON

KENNETH MCNEAL

LEWIS PRESCOTT

JOSEPH WADDLE

ROY LINTON

CLYDE WALKER

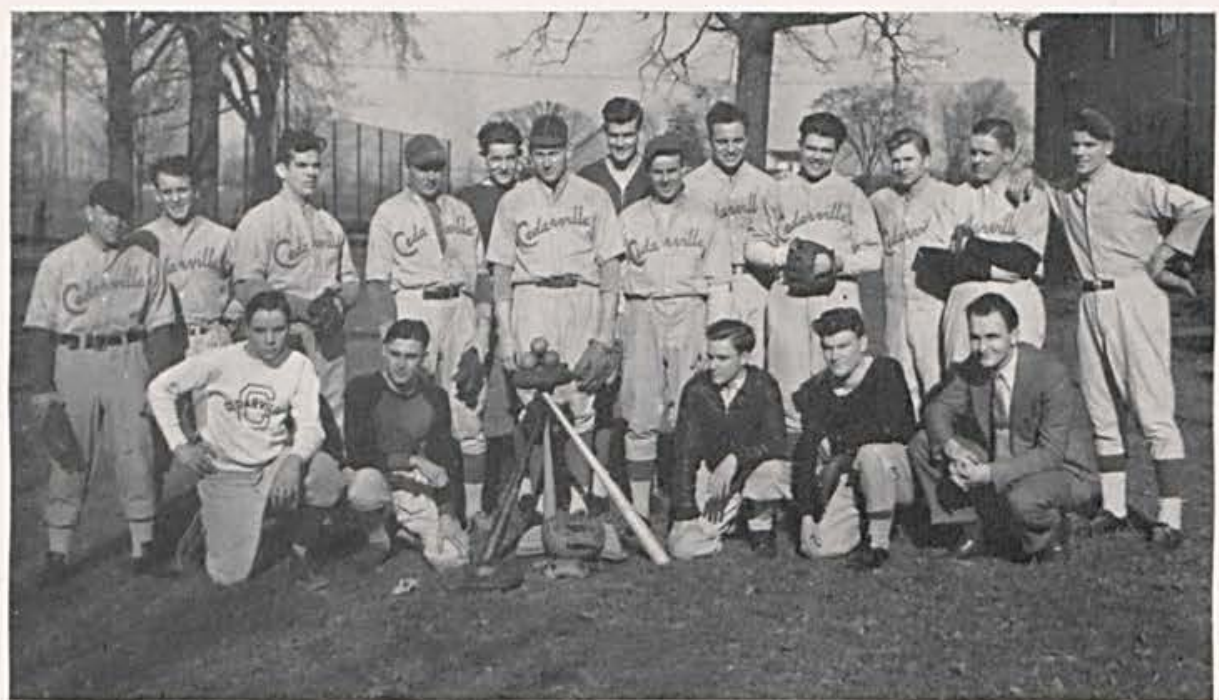




\section{BASEBALL}

Cedarville College is very proud of their 1936 baseball team. Although their team did not win the conference championship, they did play some wonderful ball. The season ended with a very satisfactory record of 5 won and 3 lost. It is the hope of the student body that with their record behind them they will do even better this year and in the future.

Prospecs for a successful season in baseball are very bright. Last year's team lost only one regular by graduation-Garlough-and several Freshmen with real ability have appeared to take his place. Although we will miss the steady pitching of "Zeke" we hope to make up in the other departments for the losses suffered in our pitching staff. And with this added power in other departments, we hope to bring the Conference Championship back to Cedarville.

\section{'37 SCHEDULE}

May 4 Wilmington ... there

May 11 Wilberforce... there

May 15 Bluffton ... here

May 19 Wilberforce... here

May 29 Bluffton ... there

June 2 Wilmington ... here

* 2 games pending with Rio Grande
* Letters were awarded to the following:

Garlough, B. Wallace, Thomas, Jackson, J. Gillespie, King, Walker, Waddle, H. Wallace, M. Thompson, and Mangaer Michael.

RESULTS OF ' 36

$\begin{array}{lrlrlllr}\text { Cedarville } & 3 & \text { Wilberforce } & 2 & \text { Cedarville } & 9 & \text { Bluffton } & 13 \\ \text { Cedarville } & 5 & \text { Defiance } & 0 & \text { Cedarville } & 4 & \text { Defiance } & 9 \\ \text { Cedarville } & 4 & \text { Wilberforce } & 13 & \text { Cedarville } & 9 & \text { Bluffton } & 1 \\ \text { Cedarville } & 8 & \text { Wilmington } & 7 & \text { Cedarville } & 3 & \text { Wilmington } & 2\end{array}$




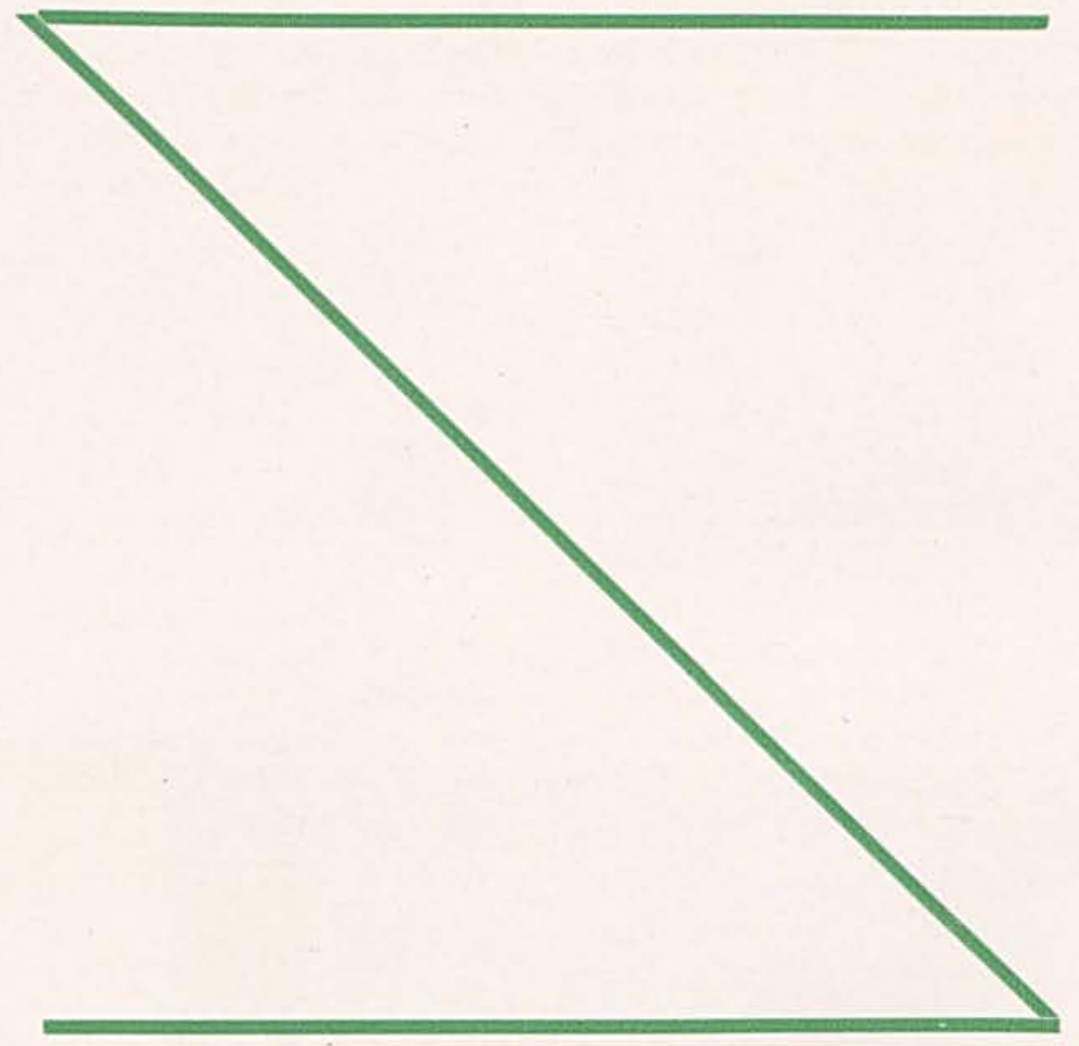



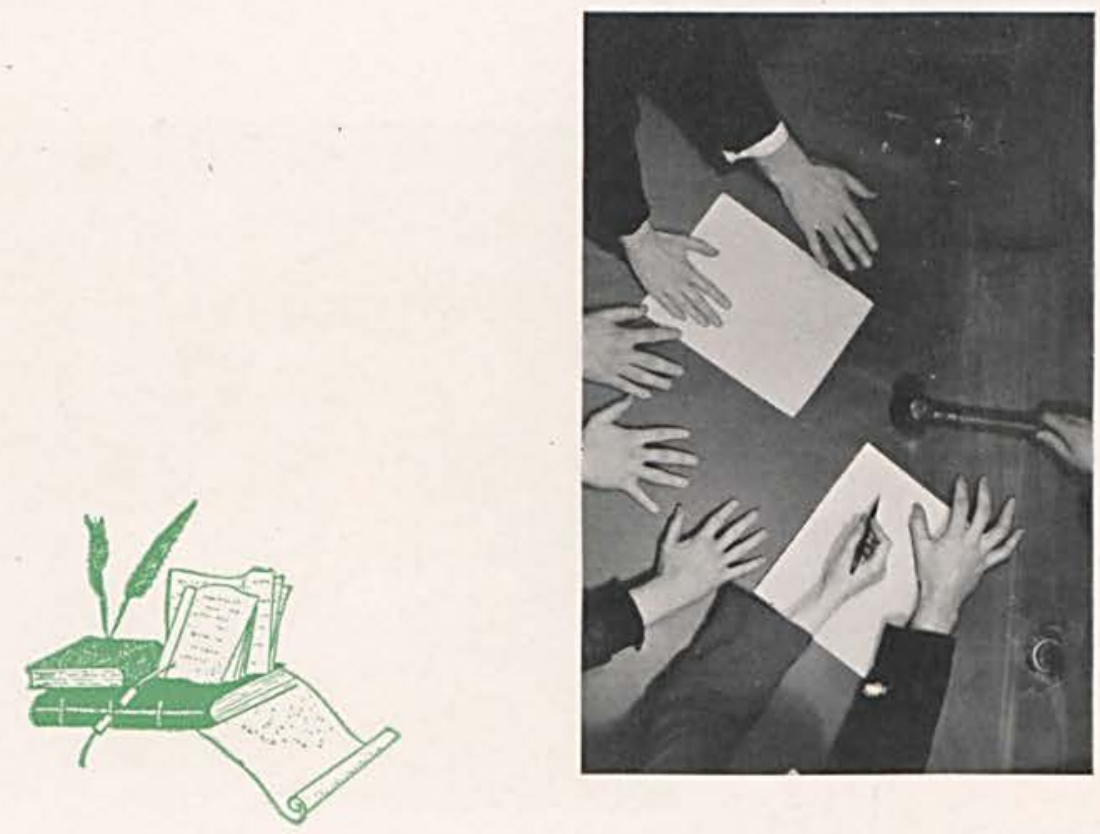


\section{Student Council}

The Student Council was first organized in the year of 1933 to take care of any student government problems.

The Council is composed of the President of the student body, who is Chairman of the Council, Secretary-Treasurer of the student body, the Presidents of each of the classes, President of the College, the Dean of Men and the Dean of Women.

The Council is composed this year of Paul Angell, President; Esther Waddle, Secretary-Treasurer; John Tobias, Senior President; Kenneth Sanderson, Junior President; Raymond Sisson, Sophomore President; Eldon Gillespie, Freshmen President; Dr. McChesney; Dean C. W. Steele; and Dean Santmyer.

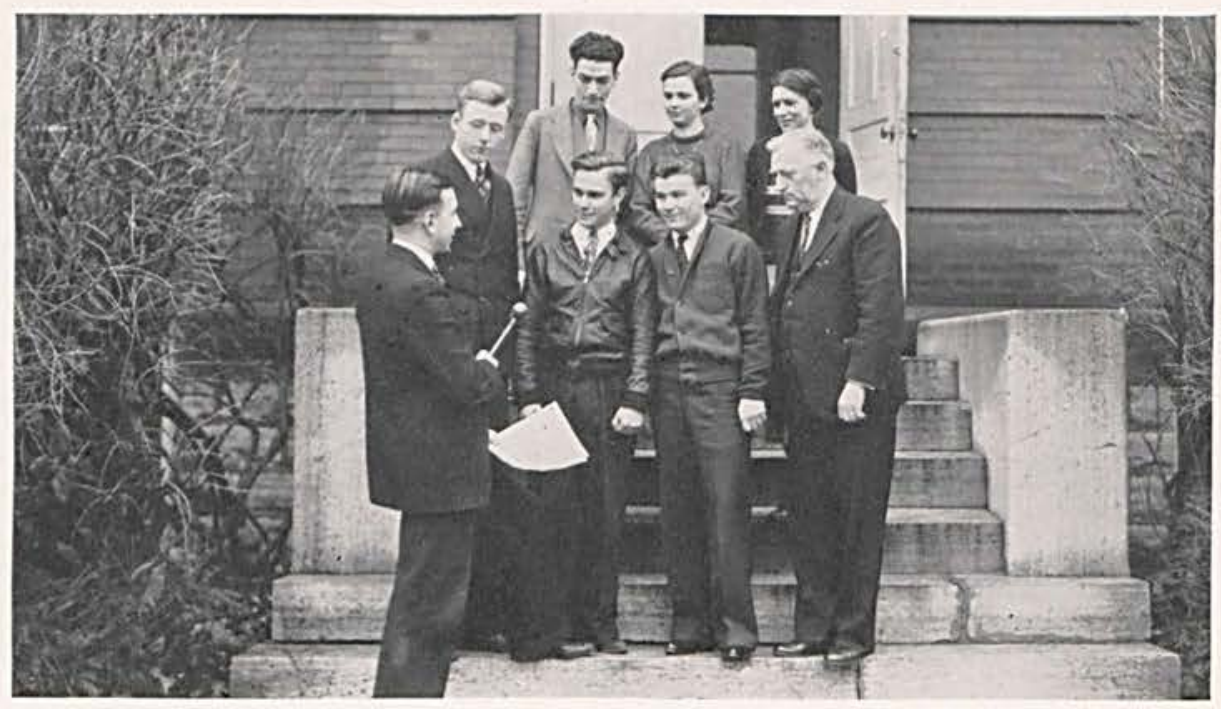




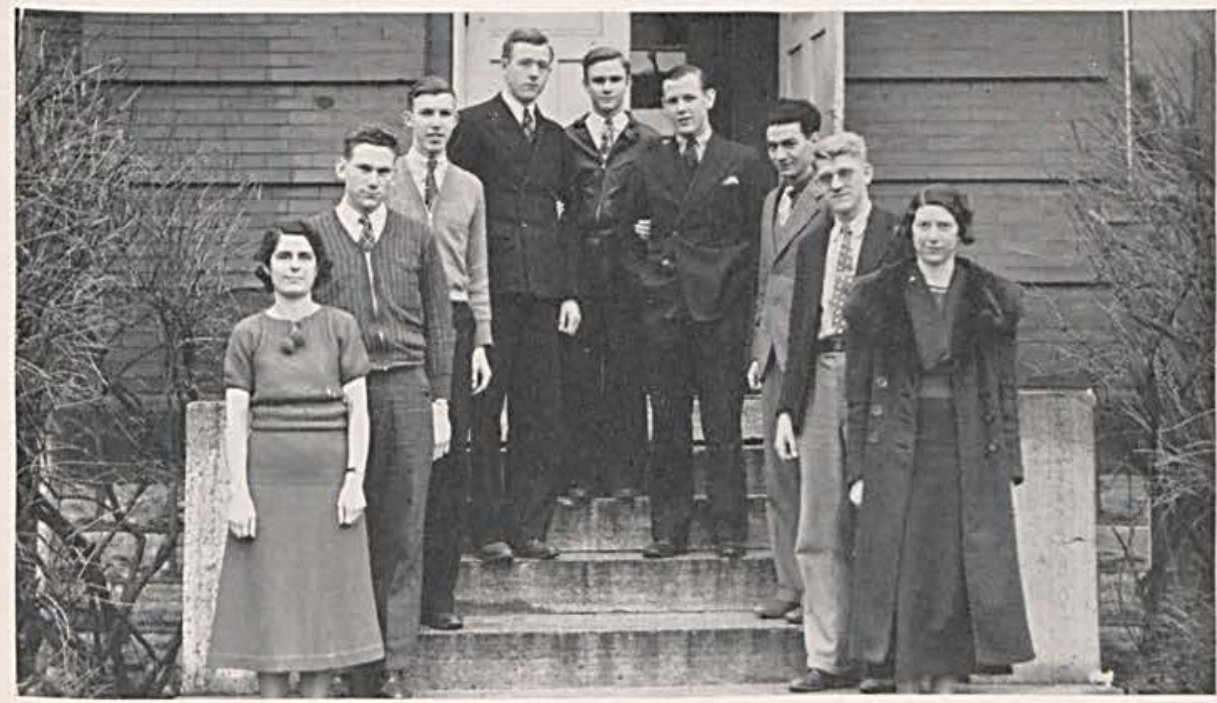

MRS. J. W. AULT

CECIL THOMAS

JUSTIN HARTMAN

KENNETH SANDERSON

RAYMOND SISSON

JOHN RICHARDS

JOHN TOBIAS

HAROLD SHAW

KATHRYN FINKE

\section{DEBATE}

This year Cedarville College inaugurated a new plan in its intercollegiate debating. For the first time there were four teams, two negative and two affirmative, each team composed of two members. The first debate of the year was a non-decision debate at Bowling Green in which Cedarville showed great promise for the coming season. The " $\mathrm{B}$ " division made its first public appearance in a debate at the Heidelberg Reformed Church at Dayton. The "A" team went to Rio Grande and succeeded in dividing the honors - the affirmative team winning and the negative team losing. The only debate held at Cedarville was with Wilberforce.

The four Cedarville teams, accompanied by Miss Basore and Mrs. Ault, went to North Manchester, Indiana, to enter the Intercollegiate $\mathrm{De}$ bate Convention. Although the teams won only eight debates and lost twelve, the season was considered to be very successful after considering the size of the colleges and the universities of the opponents.

The question this year was: That the extension of consumers' cooperatives would contribute to the public welfare. The loss of John Tobias and Kathryn Finke will be keenly felt but the six remaining members are looking forward to a successful season next year.

\section{Intercollegiate Debate}




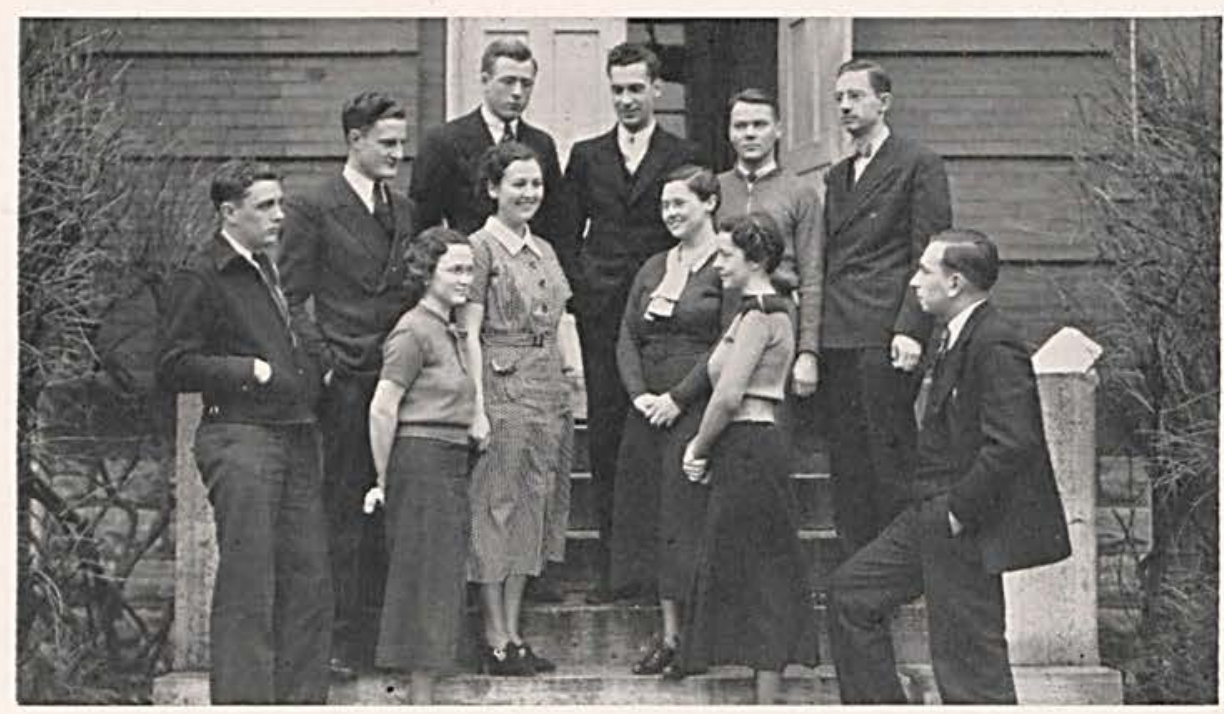

RUTH KIMBLE MARY JOHNSON BEATRICE MCCLELLAN BETTY FISHER PAUL ANGELL HARRY WALLACE HOWARD SWAIM KENNETH SANDERSON BENNETT MCNEAL ROBERT THOMPSON PROF. KUERHMANN

Many months ago we began the tedious task of compiling data for this year's Cedrus. Today we present it to you. We sincerely hope that our efforts shall not have been in vain and that you will cherish this volume as a collection of fond memories at Cedarville.

It has been a privilege and an inspiration to us to be allowed to compile this edition for you. However, since we are only human, we realize that we have made mistakes; but many years hence as you take this honored book from its shelf and as you turn its pages, we hope that you will shed a few silent tears in memory of the school days that meant so much to you at dear old C. C. If you are so affected, then we will feel that our efforts have been worthwhile.

\section{Cedrus Staff}




\section{Whispering ledars}

With Justin Hartman as editor, the fourth year of our College paper has been a very successful one. The news of the College has been presented in a very interesting and enjoyable manner. The editorials, written on College, local, and national affairs, were interesting. The "scandal department" always managed to be somewhat enlarged when the editor was not there to supervise things.

The paper had a large subscription this year and here's to the successful "Whispering Cedars" year of 1937-38.

\section{STAFF}

Editor - . . JUSTIN HARTMAN

Assistant Editor - . - CLETIS JACOBS

Sports Editor - . RAYMOND SISSON

Business Manager -.. JOHN TOBIAS

Senior Reporter .... RUTH KIMBLE

Junior Reporter . . . . GENE REED

Sophomore Reporter - . - . FRED LOTT

Freshman Reporter - GENEVIEVE JESSON

Typist -.... BENNETT MCNEAL

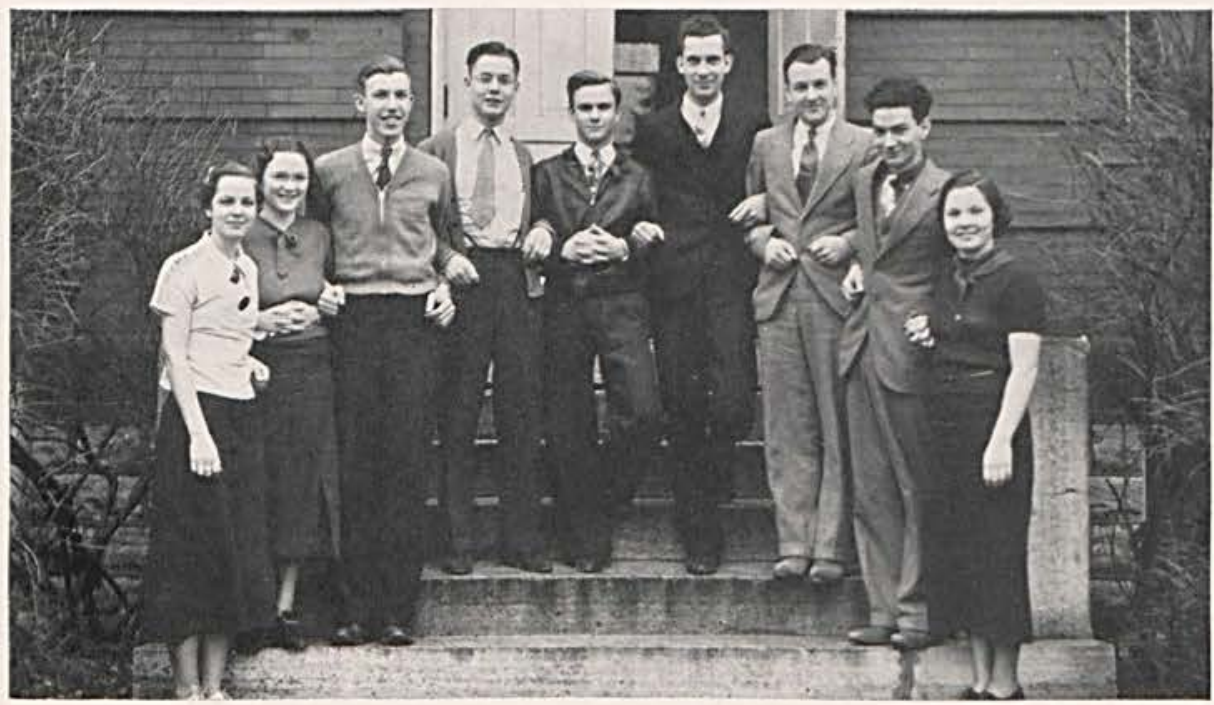




\section{y. M. C. A.}

The Y. M. C. A. contributed much to the life of the college during the past year. It has tried to bring to the college speakers that widen the student's view of life. Several speakers have given us intersting travel talks, namely Rev. Guthrie about his trip down the Rhine; Miss Santmyer about her experiences in England; Rev. Sinks about his missionary work in China; and Miss Bickett of Egypt. Others speakers have given us views of different kinds of life. Capt. Markel reviewed briefly the life of a marine, Mrs. E. Anderson told us of the social conditions of our country, and Forest Nagley the life in a C. C. C. Camp. During the year many ministers have come to us with stirring messages, that is, Rev. Duff of Yellow Springs, Rev. Simister of Xenia, and Rev. Hill of Cedarville. We have had several outstanding musical programs during the year. Frank Morrelli of Springfield gave an entertainment with his saxophone. Wilmot Fisher gave a piano concert, and members of the Y. M. gave a very entertaining program of music.

The Y. M. has cooperated with the Y. M. in sporsoring social activities during the year, such as, the College mixer.

The members who will carry on next year as officers are Kenneth Sanderson, President; Justin Hartman, program chairman; and Cecil Thomas, treasurer. Several of these officers attended a state Y. M. conference at Otterbein. The Y. M. is looking forward to a year of service in Cedarville College under their leadership.

PROF. J. W. AULT

PAUL ANGELL

PROF. C. W. STEELE ROY LINTON

JOHN TOBIAS

JOHN RICHARDS
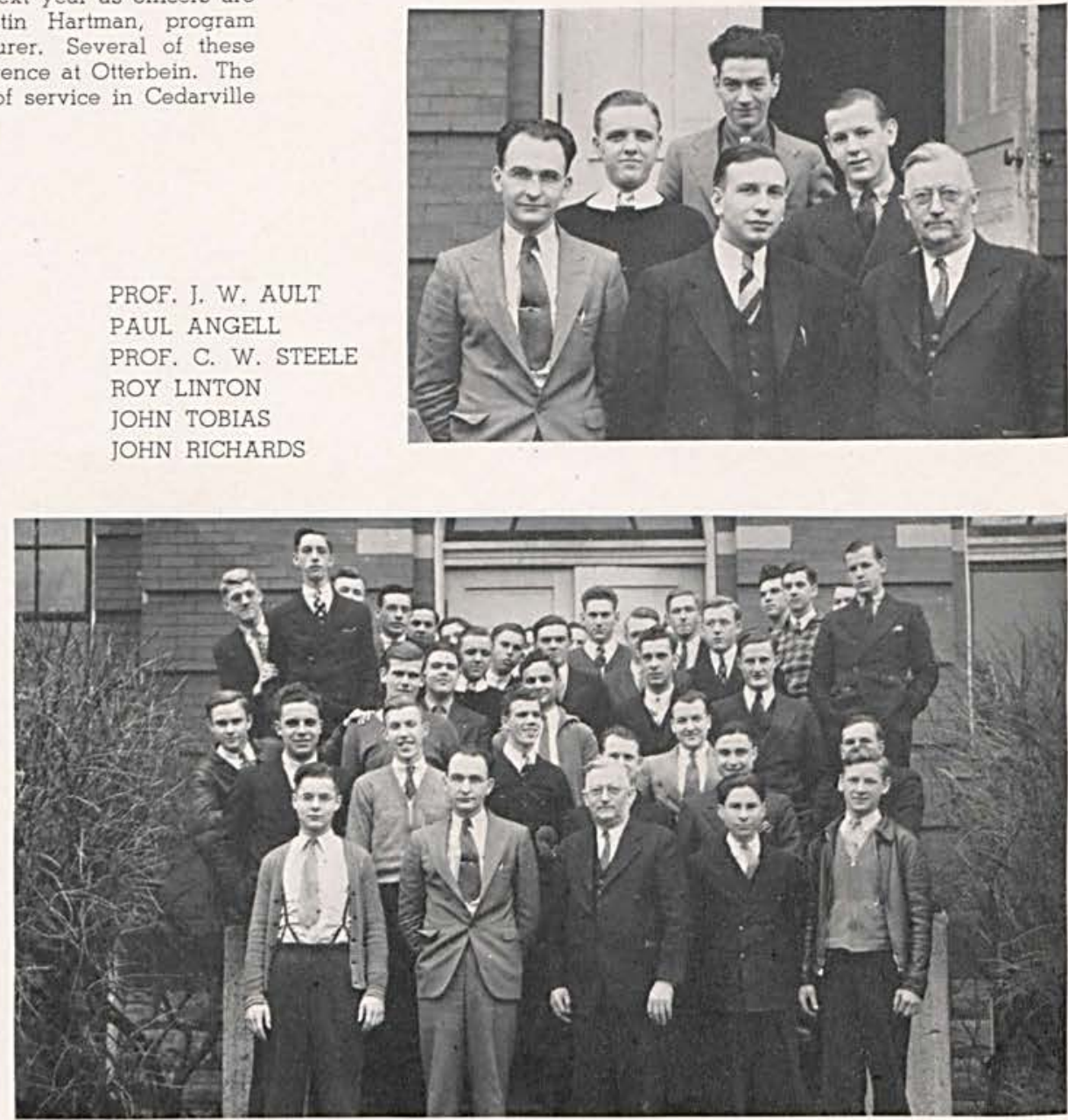

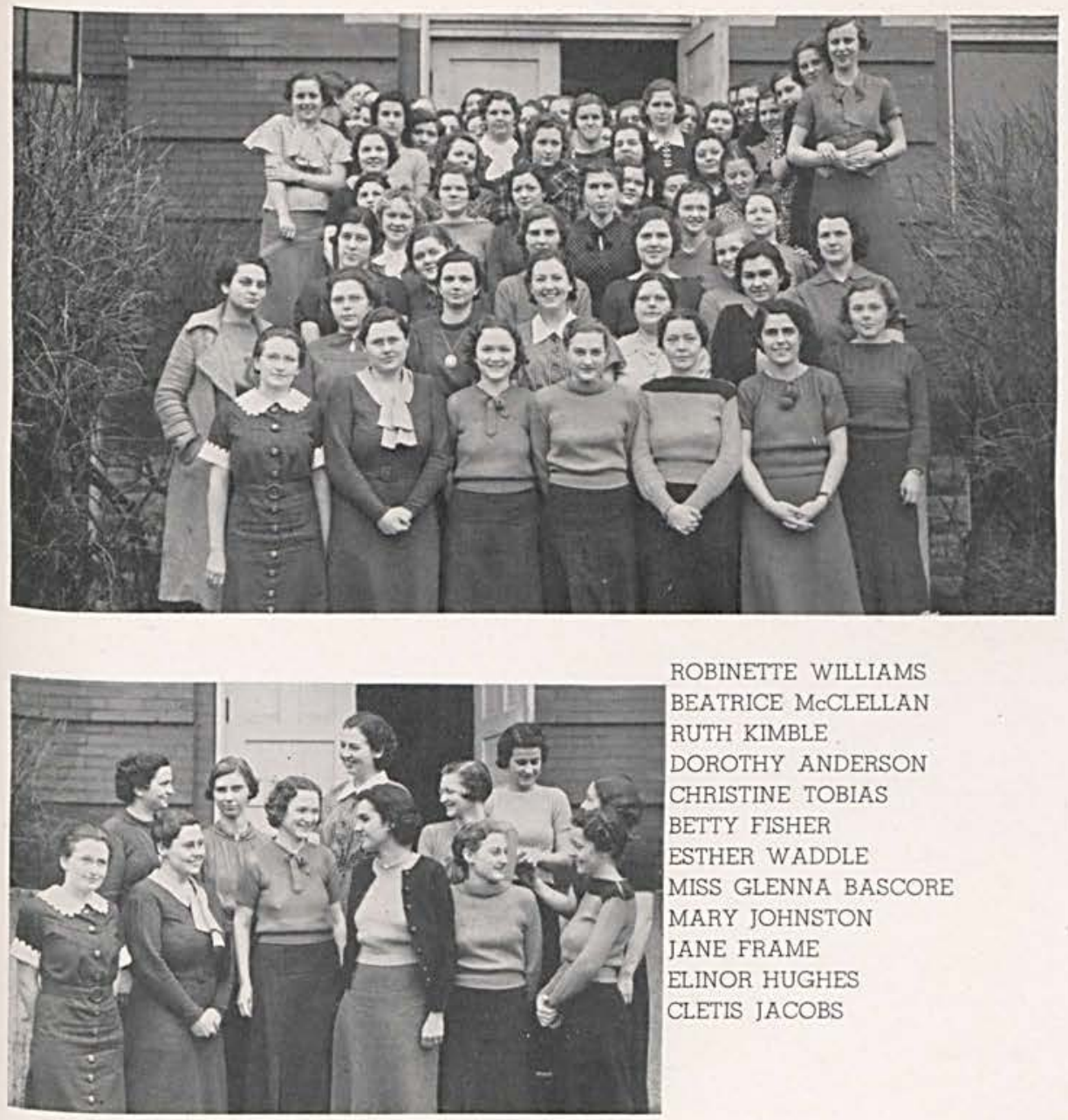

ROBINETTE WILLIAMS

BEATRICE MCCLELLAN

RUTH KIMBLE

DOROTHY ANDERSON

CHRISTINE TOBIAS

BETTY FISHER

ESTHER WADDLE

MISS GLENNA BASCORE

MARY JOHNSTON

JANE FRAME

ELINOR HUGHES

CLETIS JACOBS

The Y. W. C. A. opened the school year with a Welcome Tea at the home of Dorothy Anderson during the first week of school. During October, the Y. W. sponsored the College Hallowe'en party, giving prizes for the best costumes. The new members and the cabinet took their pledge of loyalty at the annual Committal Service in November. There followed several weeks of mystery with all the girls wondering who their secret pals might be. This mystery was ended at the Christmas party at the home of Mrs. C. W. Steele.

We started our social life of the second semester with a chili supper at the home of Geneva Slemans before one of the basketball games. During March the Y. W. put over the first successful mock wedding in many years at the home of Beatrice McClellan. On April 15, the girls had a Carnival which proved a great financial success. The Y. W. year officially ended with the Mother-Daughter Banquet on May 7 at the gymnasium.

The social life of the Y. W. C. A. if just one of the phases of its work. This year we had almost a perfect membership. We hope that next year will be just as successful.

\section{Y. W. C. A.}




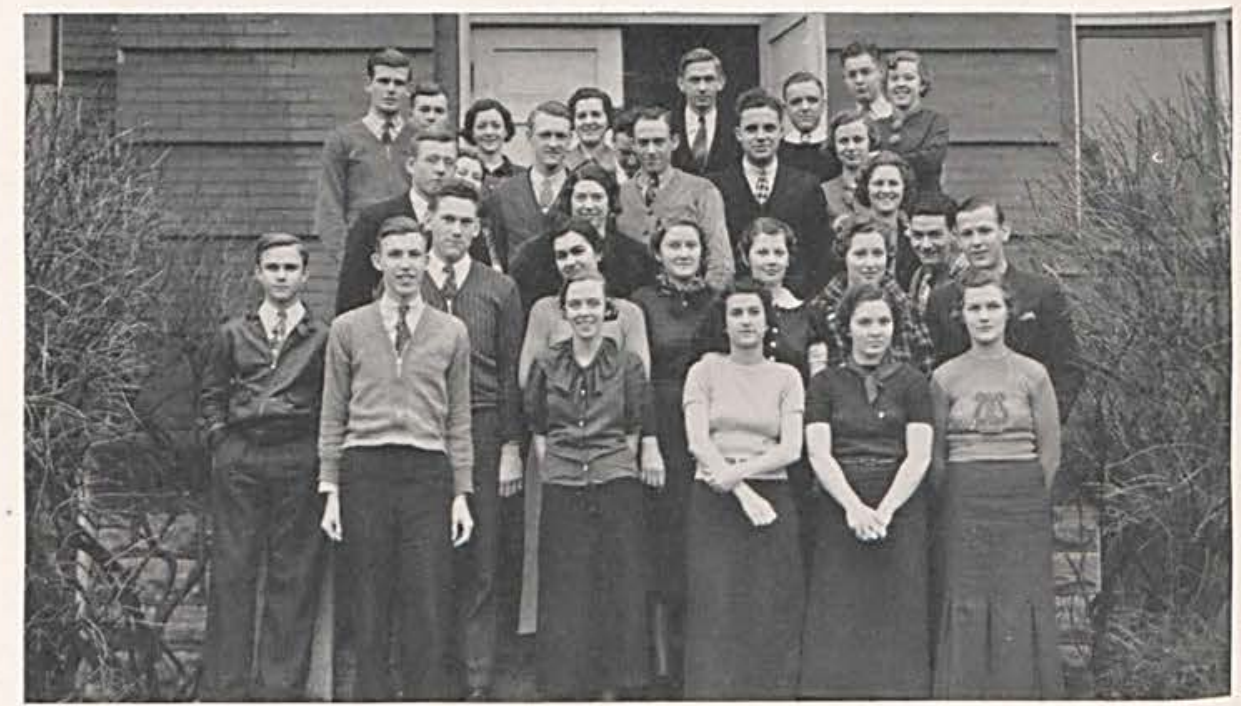

An association which has played a most important part in the matriculation of freshmen and in offering instructive entertainment all collegiates alike is the Philosophic Literary Society. Its programs have been quite educational. The most interesting among these programs were: a travel talk by Mrs. Frank Creswell, a war speech by W. W. Galloway, and a navy address by an alumnus of Cedarville College, Chaplain Markle of the U. S. Navy.

The climax of the society's season however was reached when it went on its annual "hayride." Two truck loads of hay and students enjoyed themselves thoroughly riding through neighboring communities.

To you who follow let us propose a toast: "Bigger and better Literary" and of course, "Bigger and better hayrides."

\section{Literary Society}




\section{Dramatic Club}

In members perhaps the Dramatic Club is not as large as it was last year, but it has continued its good work. Several plays under the direction of student members were given in the Y. W. room in Old Main.

The Club succeeded last spring in buying the long hoped for curtains for the stage in the gymnasium.

Miss Helen Santmyer, director of the club and head of the English Department, with the aid of the club planned the story, setting, costumes, etc. for Cedar Day. They are preparing a Greek Pageant based upon the story of Proserpina being stolen from the earth by Pluto and taken to Hades.

In the future the Dramatics club hopes to hold meetings especially devoted to costumes, scenery, and make-up.

The following plays were presented during the year:

1. "Minniquin and Manniquin."

2. "The Boy Comes Home."

3. "A Voice in the Dork."

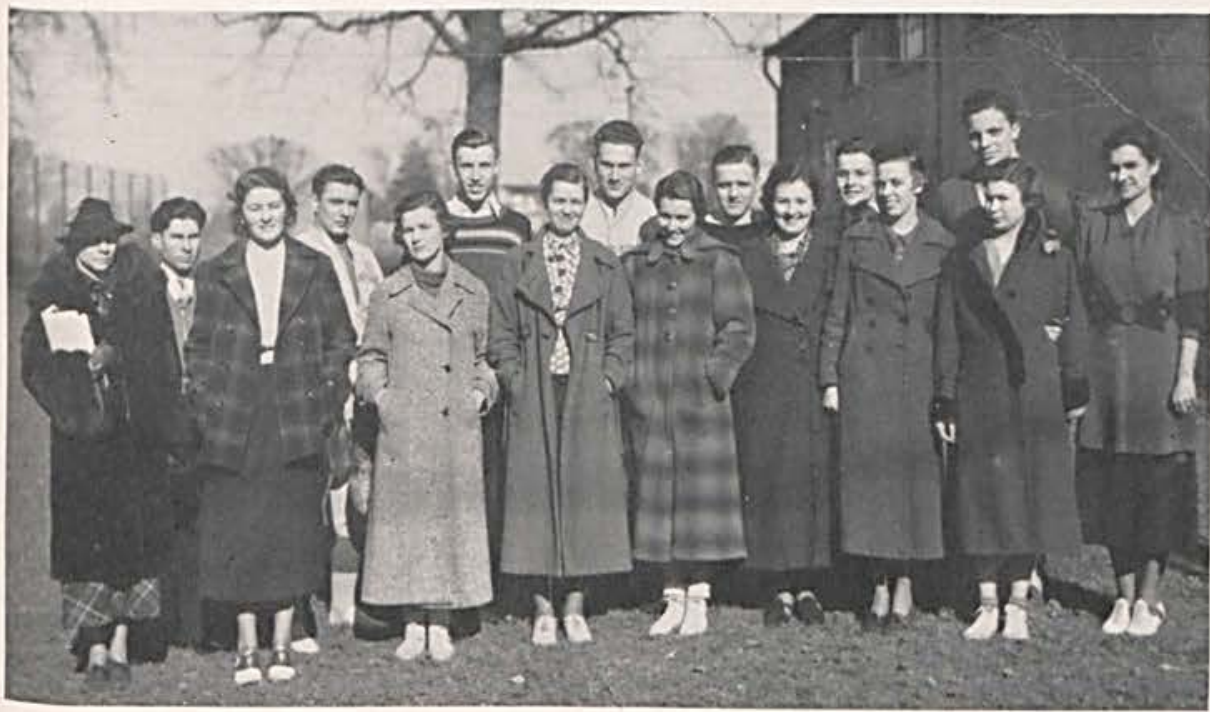



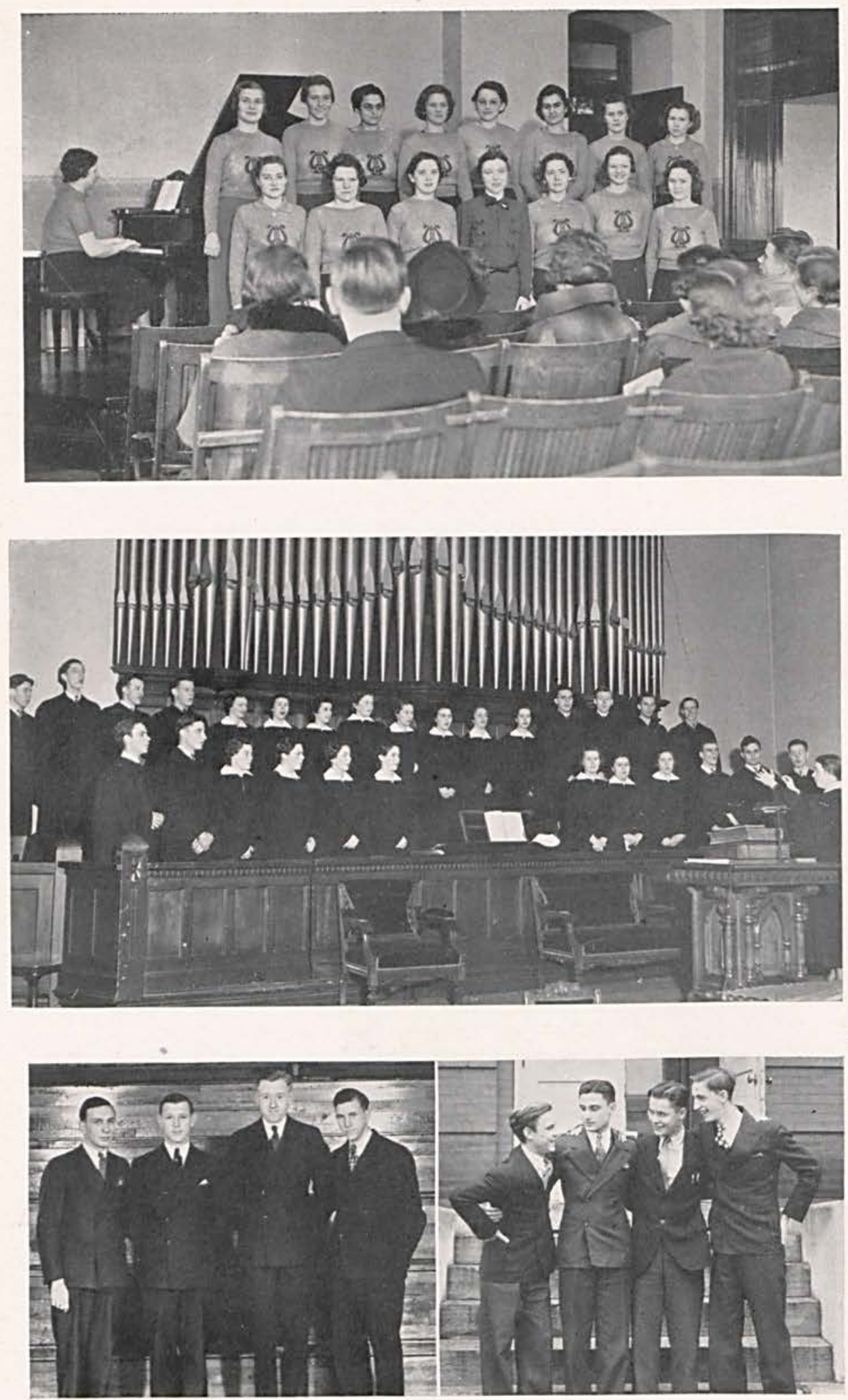
When the Girls' Glee Club was organized in the fall of 1936, the members decided upon uniforms of sweater and skirt in the college colors.

The Glee Club has made a number of appearances before high school and other audiences. They also sang for the College Day of Prayer and the Girls' Bible Reading Contest. For the spring programs they prepared a group of spring songs and the suite of Venetian songs by Ethelbert Nevin which they sang at the Song Fest and for the Cedarville Women's Club at their Spring Musicale.

The Mixed Chorus has made a number of public appearances this year on the campus as well as in nearby towns. On December 6 this group broadcast a sacred program over station WHIO. Among the outstanding appearances on the campus are a most effective Candlelight Service at Christmas; at Easter Gaul's oratorio, "The Holy City" was rendered in the Presbyterian Church; and they sang the Gilbert \& Sullivan opera, "Trial by Jury" as a part of the Sing Fest on April 29.

The Chorus meets for an hour every Monday and Wednesday evenings in the basement of the library.

Due to Garlough's return for a post-graduate course, the old quartet remained intact from last year. A new quartet of freshmen and sophomores was organized. Several appearances were made by both quartet in Cedarville, Bowersville, Carlisle, Mason, Ross, Lena-Conover and Jamestown. Programs of sacred music were given in Xenia and over radio station WHIO in Dayton.

Miss Biskett has been an able and willing instructor and our thanks go to her for the time and effort she has spent with the quartets. 


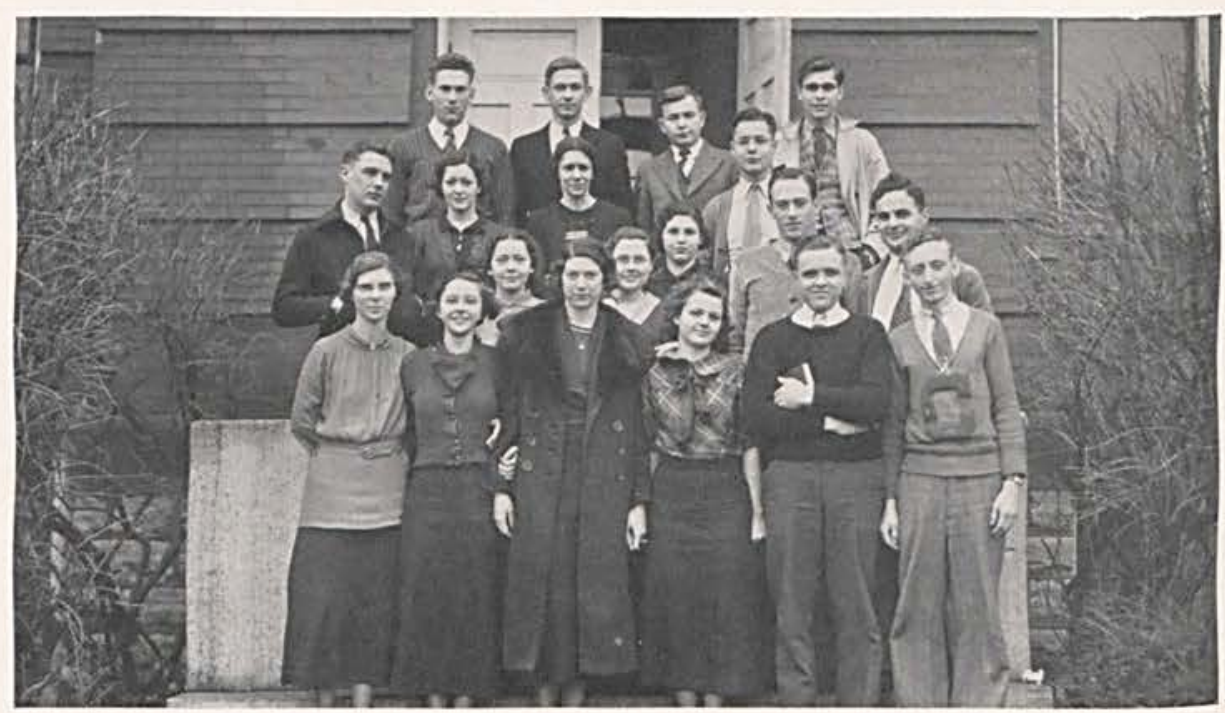

Tinkle, Tinkle, Little Bell

Come and get it

As it yells.

Each day as the little bell is rung it calls another meeting of the College Boarding Club to order. This august club meets twice a day in the basement of the College Library under the supervision and direction of Mrs. Morton and her able assistant, Mrs. Stuckey.

At each meeting, politics, religion, and social activities are widely discussed while the members consume quantities of delicious food. The motto of this organization is "Pass the applebutter", originated by John Fox, who always eats the extra pie. Mr. Elden Foulk holds the record for eating eleven slices of bread at one meeting.

We of the club believe that we will always remember the joy and fun of our club meetings.

\section{Boarding Club}




\section{Gospel Team}

The Gospel Team of Cedarville College was organized in the fall of 1936 with Kenneth Sanderson as business manager and Rachel Creswell as the assistant. It is composed of a group of young men and young women who wish to give of their time and talent to the spread of the gospel. It pays no heed to denominational lines, as students of various denominations work harmoniously in it.

The Gospel Team has held several services in churches in the neighboring cities such as Xenia and Dayton as well as in our own community. This has been a splendid experience and training for the members of the team and has doubtless been a help to the places served.

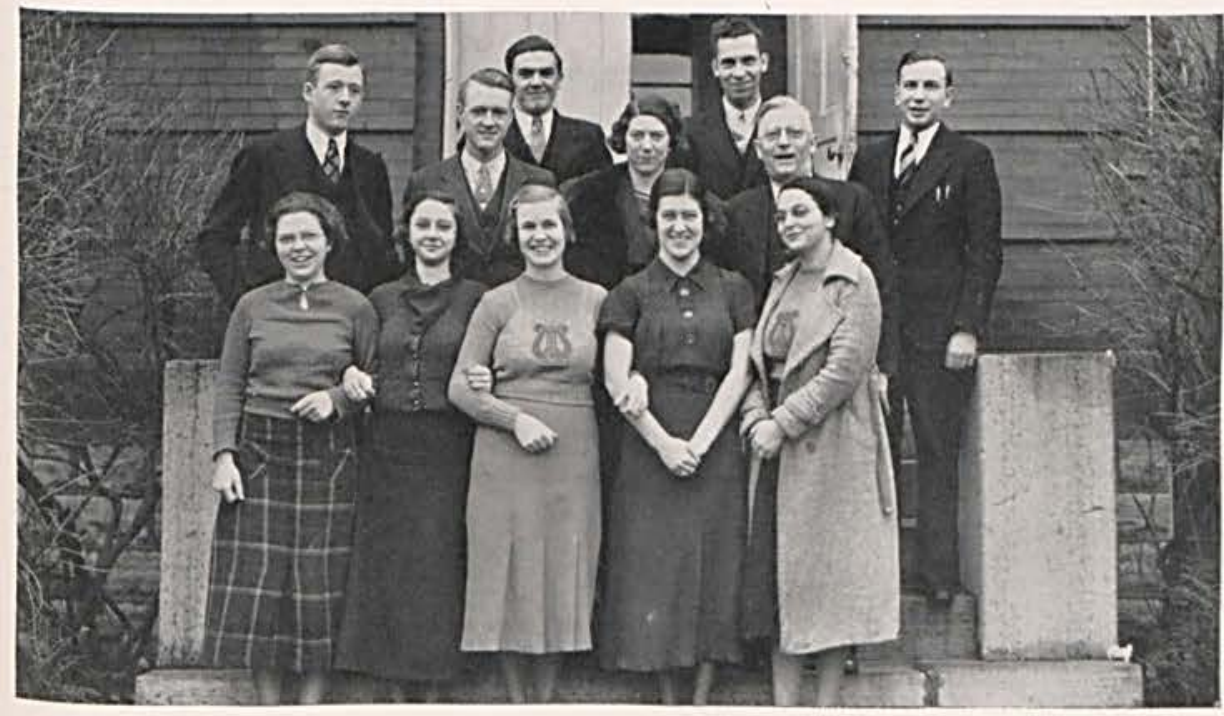




\section{Delta Kappa Sigma}

The Delta Kappa Sigma was organized last fall with Sisson, Tomlinson, and Garlough rooming at the house. After a few weeks of school, pledges were called. Lott, Linton, and John Gillespie, after several weeks of cleaning and one week of torture, were properly installed into the fold.

During basketball season, signs advertising the home games were painted and put up across the street. A pep meeting was also organized before the Defiance game.

After the second semester had started, pledges were again called. We started a little late but finally, after a complete course in housekeeping and punishment endurance, Sharpe, the two McNeals, and Peterson were enrolled in our list. Johnson, during the later part of the semester, joined the other boys as a roomer.

The fraternity had a fairly successful year but there are definitely many more things that could be done to improve it. We hope to profit by experience and make next year's organization a great success.

JOHN GILLESPIE

JOHN TOBIAS

LOREN TOMLINSON

ROY LINTON

FRED LOTT

JOSEPH WADDLE

EUGENE REED

RAYMOND SISTSON

GALE ROSS

PROF. AULT

BLUTCHER GIBSON

FRED HEIFNER

HERBERT CUMMINGS

HOWARD SWAIM

JOHN RICHARDS

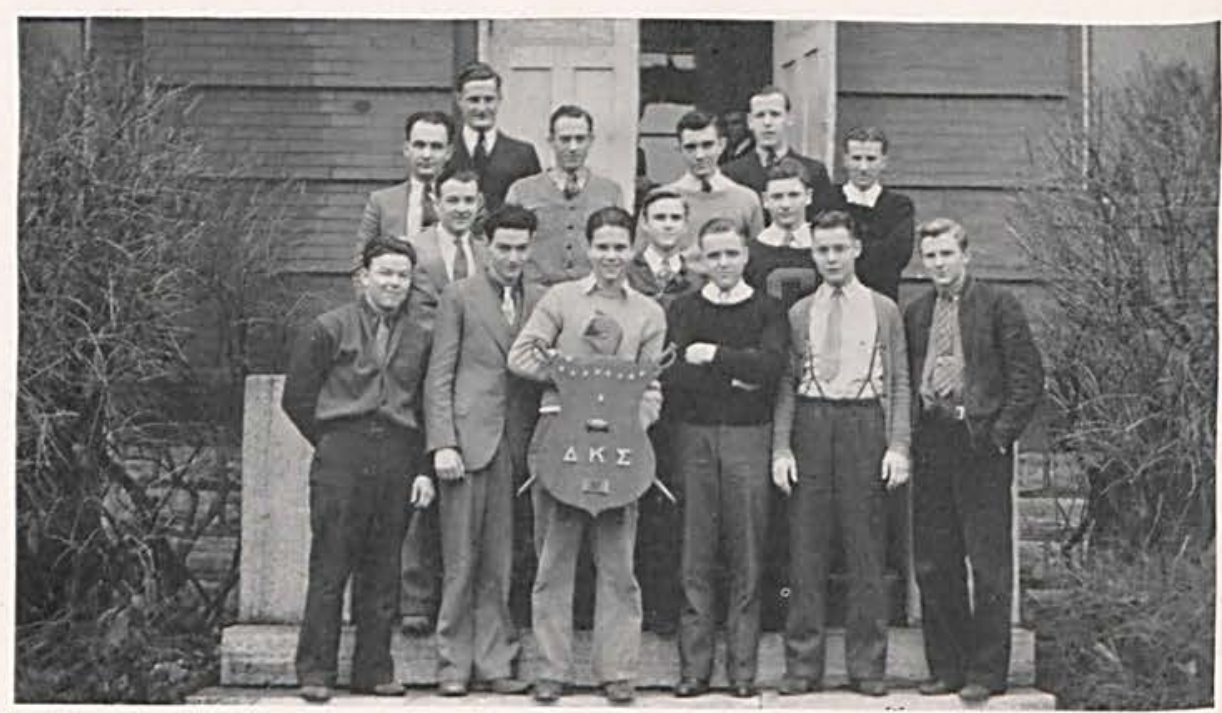




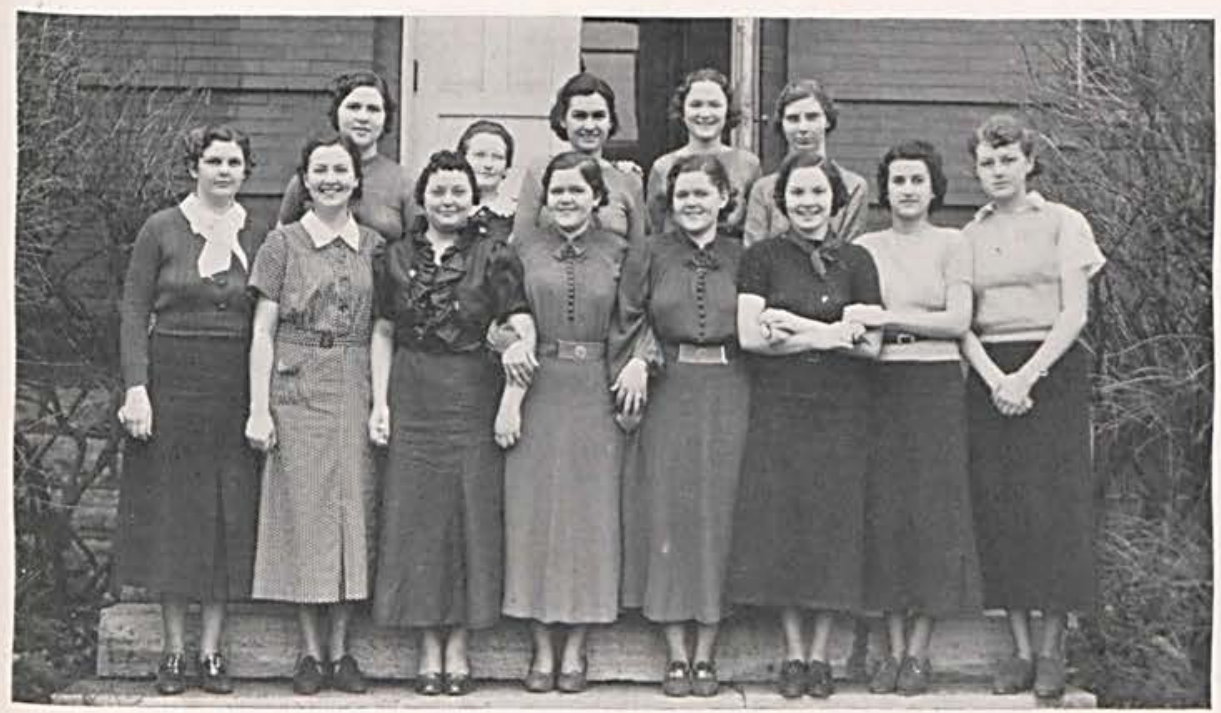

LOIS WADIILE

MARY JOHNSON

ELIZABETH RICHARDS

JANE KENDIG

JEAN KENDIG

CLETIS JACOBS

ELINOR HUGHES

ESTHER SHUMP

MARTHA BRYANT

ROBINETTE WILLIAMS

DOROTHY ANDERSON

RUTH KIMBLE

MISS GLENNA BASCORE

The Chi Sigma Phi, in a pleasant round of activities and fun has increased in number to 26 .

Last summer the charter members and Mrs. Work spent a most delightful week at Russels' Point. At an old clothes party last fall, the girls showed hilarious results of having ransacked the attic. Later, on a scavenger hunt, all black cats in town were endangered, school teachers were never so scarce, and two-handled bean pots so hard to find.

The pledges were formally and informally initiated into the sorority at a party held at Knott's with Dorothy Anderson as hostess.

This spring the girls have had a wiener roast at the gun club and many more good times are being planned.

\section{Chi Sigma Phi}




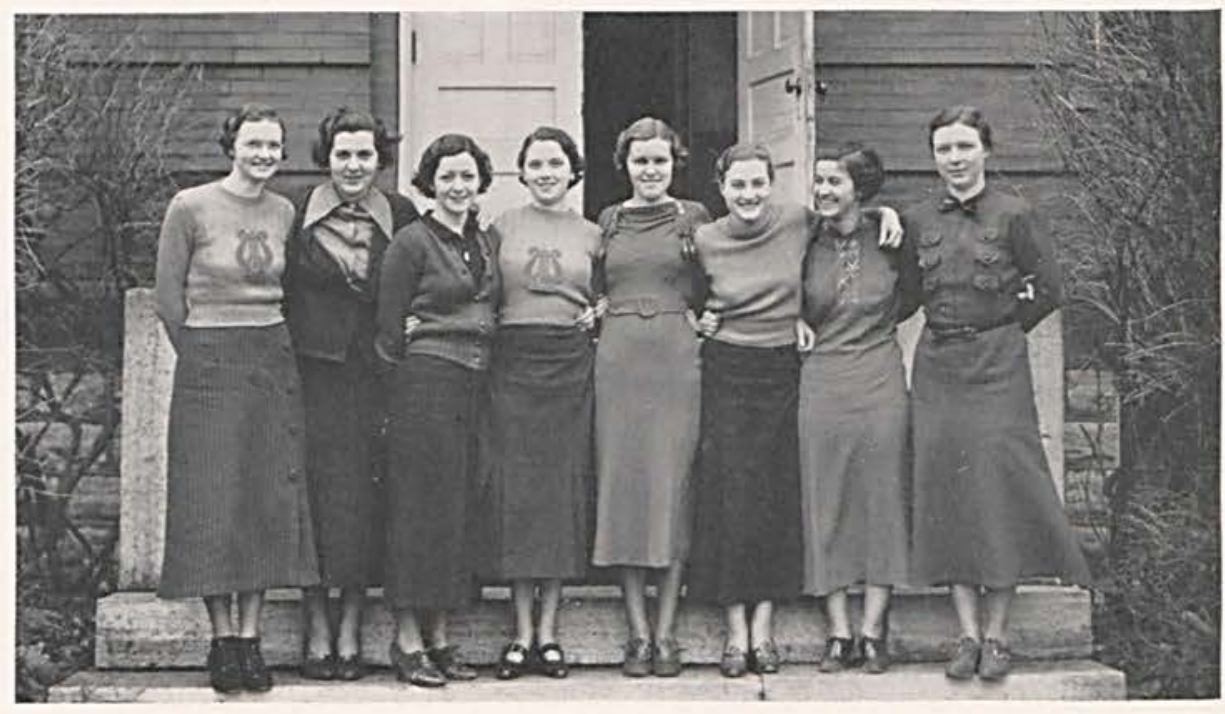

JANE FRAME

JULIA HOLLAND

HELEN SEAMON

MARGARET NELSON

PAULINE LONG

CHRISTINE TOBIAS

MARIORIE GRAVES

MISS MILDRED BICKETT

On February 24, 1937, Alpha Theta Tau celebrated its sixth birthday. The sorority was organized in 1931 by eight girls who were students in Cedarville College at that time. The group acted as an independent sorority until the fall of 1936, when it came under the sponsorship of the college. During these years Alpha Theta Tau has cooperated several times with the Delta Kappa Sigma in providing entertainment for the members of both organizations. At present, there are twelve active members in the sorority.

\section{Alpha Theta Tau}




\section{College Song}

Cedarville's a college in a grand old state, Builded by the hands of a Maker Great

Guiding eager students to the open gate Of dear old Cedarville.

Fitting them for champions of the truth and right Arming them completely for the coming fight Leading them to victory over wrong and right At dear old Cedarville.

Senior, Freshman, Sophomore, Junior, too Join your hearts and efforts in everything you do "Onward, Upward!" be your motto still Follow close the leading of our Dear old Cedarville.

I want to go back to old C. C. The best school in the land And go to all the games again And shout Rah! Rah!

To Alma Mater we will pledge Our love and loyalty I want to go back, I gotta go back To old C. C.

At Cedarville College, we get our knowledge We slinga da ink an' pusha da pen along. At Cedarville College, we get our knowledge We slinga da ink an' pusha da pen along. We slinga da ink, da ink, da ink, And pusha da pen, da pen, da pen, We slinga da ink an' pusha da pen along. At cedarville College we get our knowledge We slinga da ink, an' pusha da pen along. 


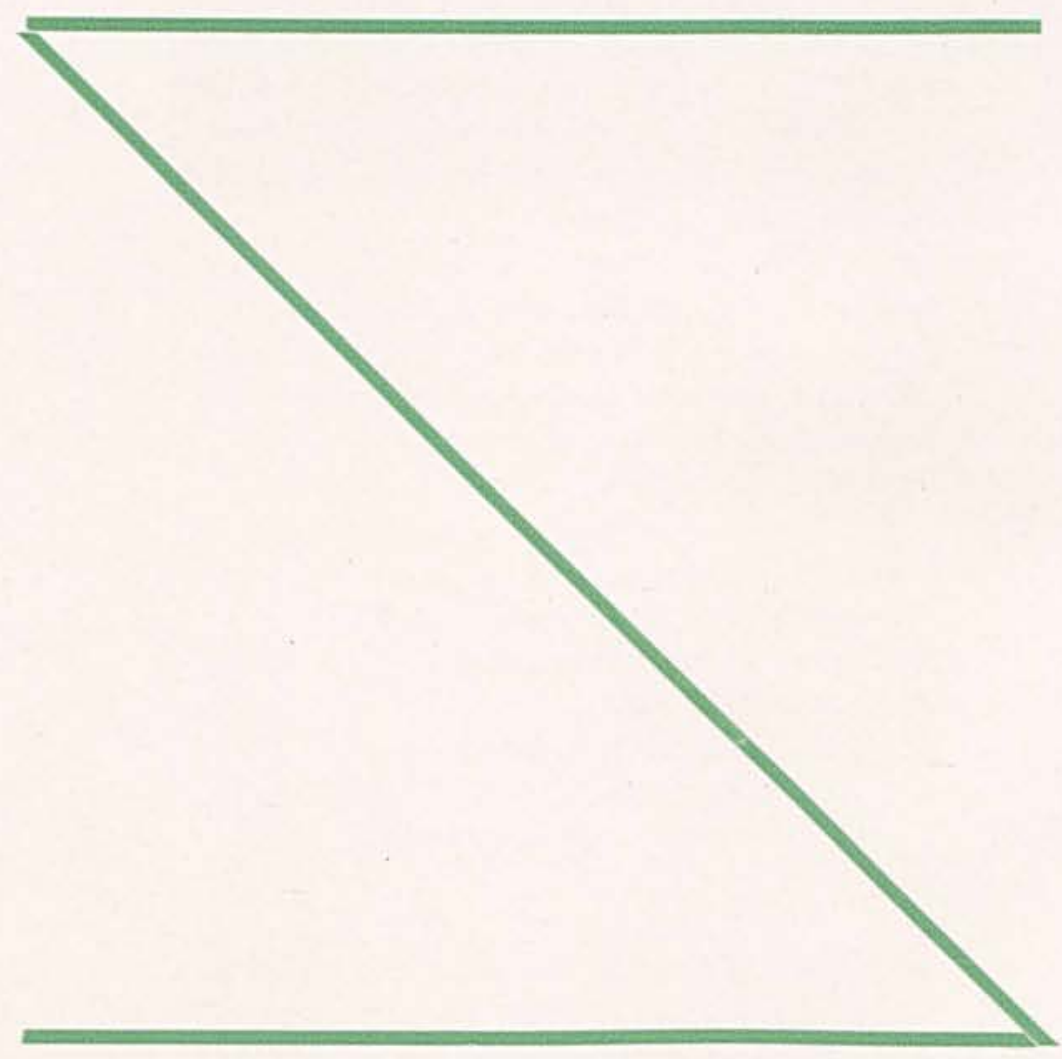




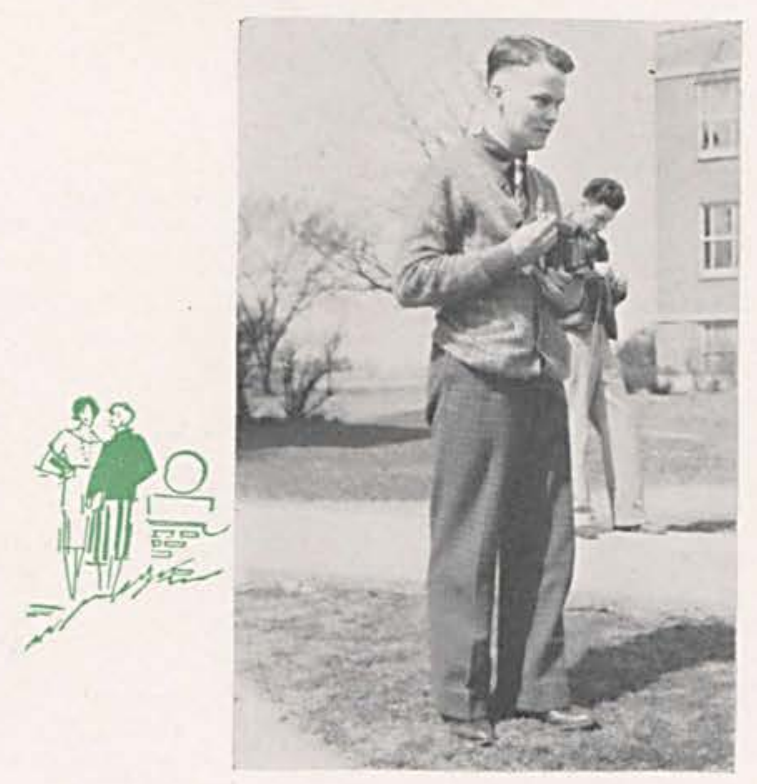




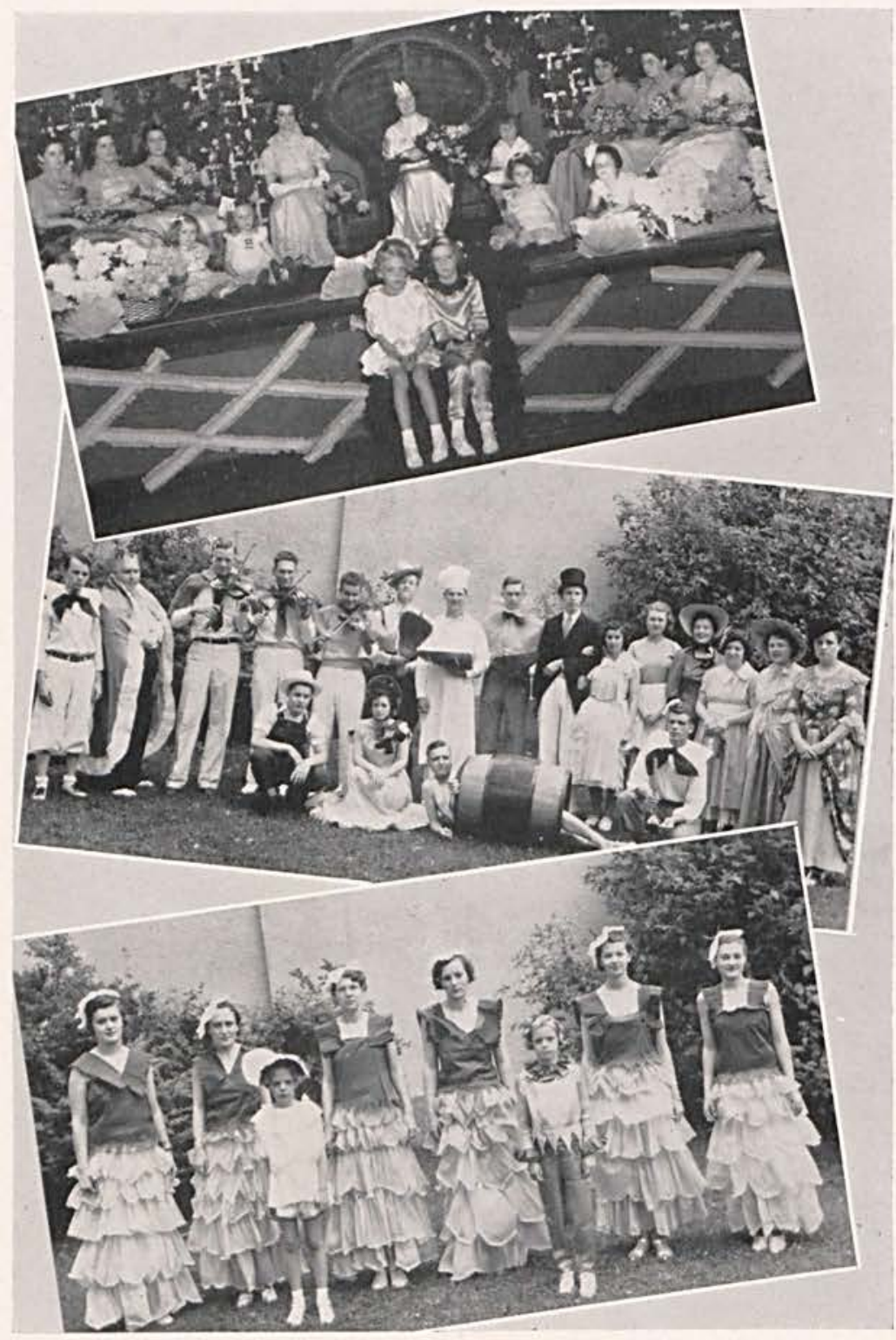

CEDARVILLE 


\section{CEDAR DAY » 1936}

The time honored festival of Cedar Day was started by crowning the Queen, Anna Jane Wham, by the Queen of '35, Luella Robe. In these few pictures we hope to portray the beauty of that pageant, and may this tradition last throughout the years of Cedarville College.

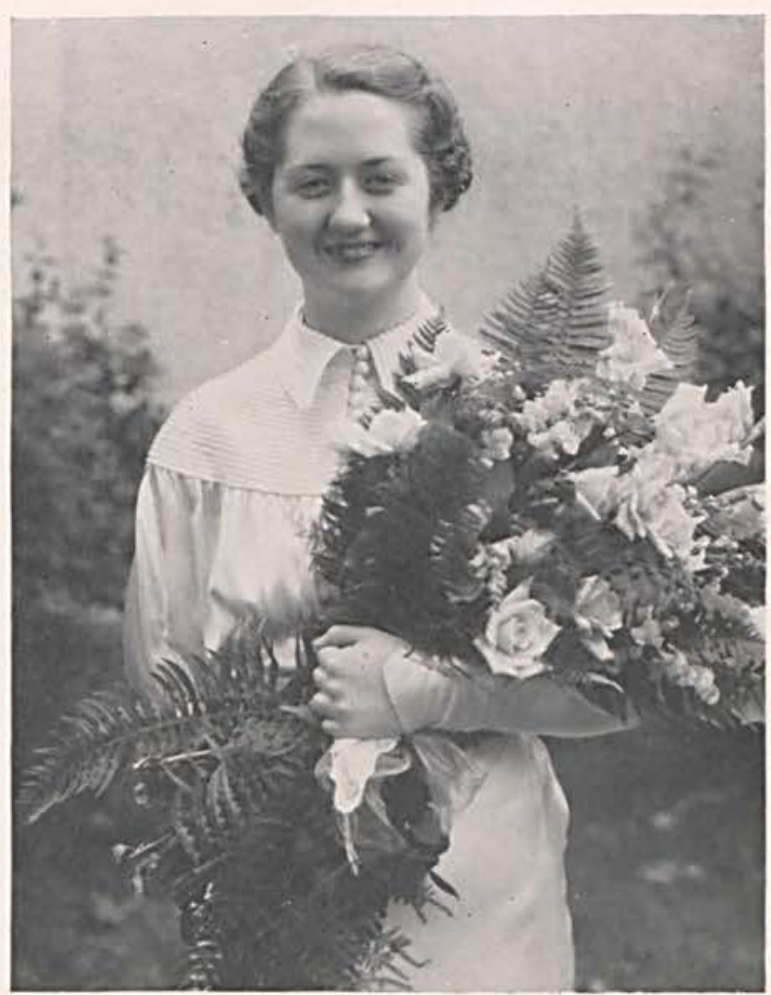




\section{Cammens Cammera}

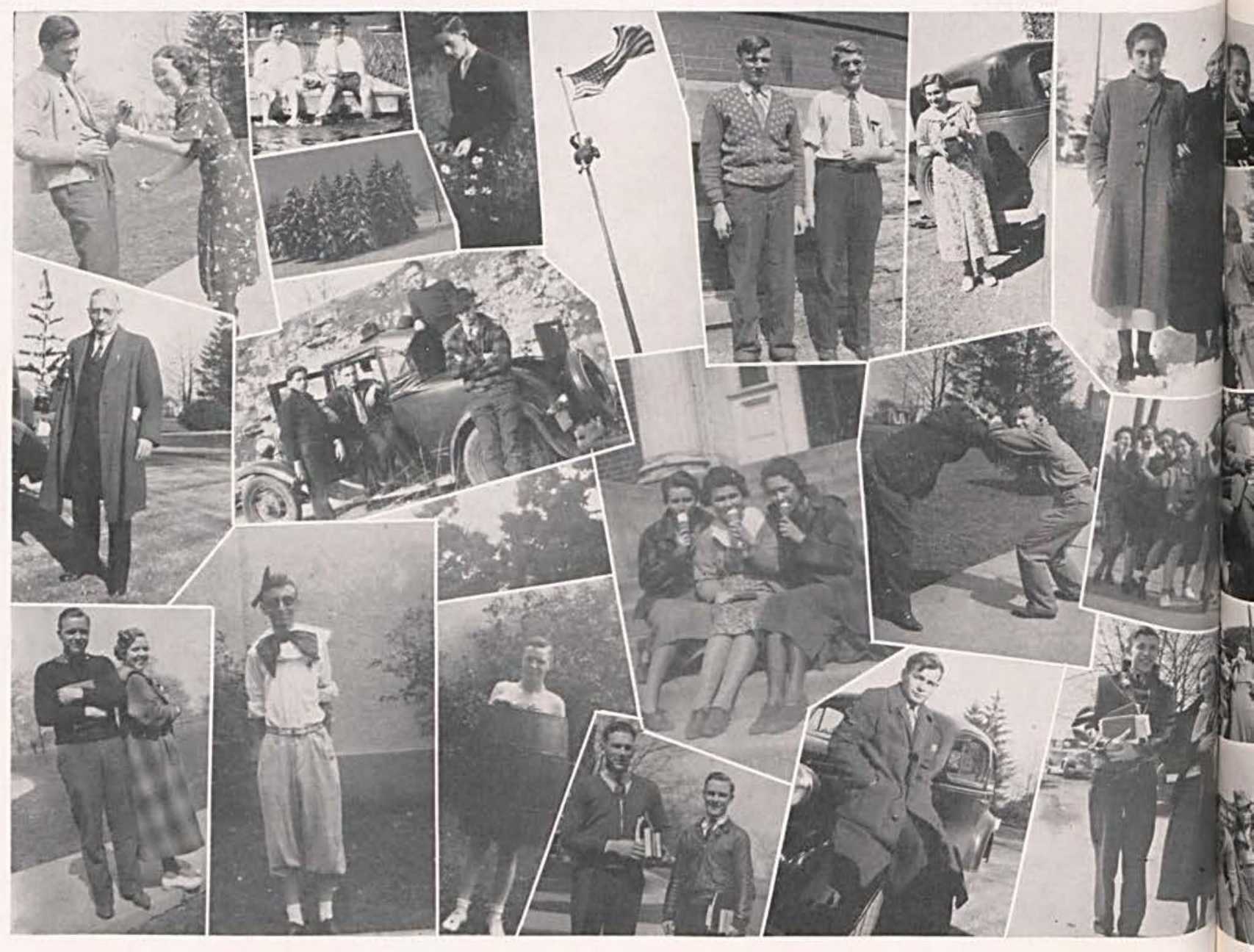




\section{Features of}

\section{HALLOWEEN PARTY}

November 4th, 1936, brought weird sights to the Alford Memorial Gymnasium. There were ladies with their canes attempting to pass as gentlemen and men in their spirts flippantly parading their most appealing features. After entering through a black tunnel the masqueraders were greeted with a knock on the head from some mysterious inanimate object. Everyone paraded around the gym trying to keep all the others guessing who they were.

Mrs. Ault had charge of the difficult task of picking the winners, and awarded first prize to James Anderson as Satan with Dorothy Anderson and Mary Johnson as his helpers. Joe Waddle and Gale Ross were the funniest; Gene Reed, the best original; and Miss Basore and Euridice Collins were the nitwits.

A pleasant evening of entertainment was furnished by the Y. W. C. A. who completed the party in true Halloween style with refreshments of pumpkin pie and cider.

\section{$\gg \gg \gg$ \\ METHODIST PARTY}

On Thursday evening, September 22, 1936, the Epworth League of the Methodist Church entertained the student body and faculty with an international party. The gymnasium was decorated for the occasion with flags of the various countries. Miss "Tommy" Thompson, recreation leader from Ohio State University, directed a number of folk games from different countries.

Refreshments of salad, nut bread, and iced tea were served by the Epworth League.

\section{$\gg \gg \gg$ \\ U. P. PARTY}

The second day of school, Thursday, September 10th, the United Presbyterian Church invited the College students to attend her homesickness chaser. The snake dance couple parade wandered up and down, in and out of Cedarville. About the only thing missed was Berk's checking up on the new girls. The groups then returned to the church where appropriate games were played. The call for lunch caused a hurried scramble to find partners. Sugar was looking for salt, shoe was hunting for stocking, and Roy was hunting for Gretchen. After the lost were found, the students gathered around a blazing campfire where games were played and songs sung.

The evening seemed to be a very successful one considering all the friendship formed, so we considered the school year officially opened, and then trouped happily to bed.

$$
\gg \gg
$$

\section{PRESBYTERIAN CHURCH PARTY}

On September 1 the Presbyterian Young People had charge of a social mixer with Mrs. Guthrie acting as hostess. The mixer was in the form of an auto party. The first part of the eveningwas spent in the gym where games and contests were held among different groups, each group representing some automobile.

From the gym we went to Rev. Guthrie's home where he acted as judge in trying several cases which were brought up in the auto court. Severe penalties were inflicted on those students found guilty of parking, speeding, and similar charges. After that we all went to the filling station in the kitchen where the order to "fill 'er up" was promptly carried out. 


\section{"YOURS TRULY WILLIE"}

"Please pass the sugar" was a familiar phrase heard at the dinner table of the Phiper family, for William Phiper, Jr., Roy Linton, better known as Yours Truly Willie, liked sugar on his bread. Mom and Pop Phiper, Mary Johnston and Justin Hartman, had a terrible time with their young son, teaching him that "The Phiper Paint and Paper Company" was more euphonious.

Willie's birthday and his departure for college were celebrated by a gala radio broadcast conceived by "Rip", James Anderson, the older brother. The whole family and many friends took part. Grace Eleanor Phiper, Betty Shaw, the older sister, read poems; Evelyn, Martha Bryant, Rip's friend, played the piano; Hugh Knox, Kenneth Sanderson, Grace's beau, sang; and Virginia, Rachel Creswell, Willie's weakness, sang accompanied by the "wicked ukelele"; the voice of Willie (?) climaxed the program.

The broadcast was a "howling" success due to the personality of the announcer, Gene Reed, and the efficiency of the electrician, Micky Cummings, and the strong vocal cords of "Little Willie", who at the last minute swallowed a collar button. It was removed, however, by much shaking and pounding, and all ended well with Pop getting his business speeded up, Mom satisfied with her problem family, Gracie getting her man, Rip, his girl, and Willie going off to college.

P.S. Virginia also got her first kiss.

\section{$\gg \gg \gg$ \\ "SPEEDING ALONG}

The Cedrus Staff opened the throttle in a fast moving comedy at the Cedarville Opera House on December 8, 1936. The modest Bobby Larrabee, Cletis Jacobs, was liked by everyone, but especially by the easy going Jack Curtis, John Richards. The sneaking Paul Stevens, Bennett McNeal, tried to win the hand of Miss Bobby also; but between Mrs. Newcome, Mary Johnston, his guest, and her daughter Vivian, Betty Fisher, he was unable to make any progress. Mrs. Newcome's angel child, Angela, Helen Seamon, and Wuggins, an orphan adopted by Bobby, Raymond Sisson, were forever getting into trouble and were always arguing. "I do"- "You don't" were familiar outbursts by these howling brats. Thornton Hathaway, James Anderson, with his "Speed King" had more trouble than he could solve alone, what with Charlie Dogberry, Harry Wallace, being none too gently tapped over the head just before the race so the Speed King would have no pilot. Molly Malloy, as reporter, Dorothy Anderson, kept everyone informed as the plot thickened and Tom Gallagher, Robert Thompson, announced the race. Granny, Ruth Kimble, and her "children" followed the "Speed King" all the way to victory in spite of the continual giggling of Miss Lavina, Beatrice McClellan, and her fustrated fisherman, Justin Hartman. This was directed by Miss Bascore.

\section{$\gg \gg$ \\ MEN'S BIBLE READING CONTEST}

Kenneth Sanderson received first place in the annual Men's Bible Reading Contest held November first in the Methodist Episcopal Church.

The other prizes were awarded to Justin Hartman, second; Robert Thompson, third; Roy Linton, fourth; Albert Grube and John Peterson, a tie for fifth place.

Dr. C. M. Ritchie, who provides the material awards for the contest, made a brief statement on the purposes of the contest. The College Mixed Chorus furnished the music for the program. 


\section{BASKETBALL BANQUET}

Cedarville College's first basketball banquet was held Wednesday evening, March seventeenth, in the College Gymnasium. The banquet was given in honor of Cedarville's champion team which won eight out of twelve games.

The Ladies Advisory Board of the College served the dinner to one hundred ten students and members of the faculty. The tables were beautifully decorated in green and white to carry out the St. Patrick's Day theme. Mr. John L. Dorst acted as toastmaster for the evening. James Anderson gave the welcome address followed by a response from Harry Wallace. Dr. McChesney gave a brief history of former college teams and Coach Ault presented numerals and letters to members of the squad. Immediately following the banquet, Mr. Clifford Bearmore, showed motion pictures of the Olympic Games held last summer at Berlin, Germany. He also showed scenes from the "Olympic Village" and from the winter games held at Lake Placid four years ago.

John Gillespie, assistant physical education director and student manager, originated the plan and it is expected that a banquet of this sort will become an annual affair.

\section{$\gg \gg$ \\ HOMECOMING}

The largest crowd ever entertained at such an event attended the Cedarville College Homecoming Saturday evening, February 6, in the Alfred Memorial Gymnasium. The Women's Advisory Board server over two hundred fifty alumni, students, and friends of the College. The tables were attractively decorated in the College colors. The program consisted of group singing led by Miss Bickett and several numbers by the quartet composed of Verner Garlough, Kenneth Sanderson, John Richards, and Paul Angell.

Following a roll call of the classes in which the class of had the largest attendance, Cedarville met Rio Grande on the basketball floor and in a teri rifically close battle Cedarville tasted defeat by a score of 25 to 27 .

\section{$\gg \gg$ \\ COMMITTAL SERVICE}

The Y. W. C. A. Committal Service was held in the Presbyterian Church Thursday evening, November nineteenth. This service, written by Frances McChesney, daughter of Dr. and Mrs. McChesney, is held every year at this time. Music was furnished by Miss Mildred Bickett and by a quartette composed of Beatrice McClellan, Ruth Flory, Kathleen Ehman, and Genevieve Jesson. At this service, the Cabinet members and new members pledge their loyalty to the Y. W. C. A. and the old members renew their covenant.

\section{$\gg \gg \gg$ \\ WOMEN'S BIBLE READING CONTEST}

The most interesting contest ever conducted for the girls of Cedarville College was held in the Presbyterian Church on Sunday night, April 11th, 1937.

Margaret Nelson and Bertha Oleyar tied for first place in this contest. Genevieve Jesson received third place, Grace Bickett, fourth, Wilma Grimes and Katherine Harbough tied for fifth place.

The Girls' Glee Club and the College Harmonizers furnished the musical program. The contest was held before a capacity audience. 


\section{MOCK WEDDING}

The Y. W. C. A. held its annual mock wedding at the home of Miss Beatrice McClellan, near Xenia. The bride was Miss Mildred Beard, and Miss Dorothy Anderson was the groom.

The McClellan Home was beautifully decorated with sprigs of cedar tied with white ribbon. In front of the fireplace stood an arch under which the bride and groom were united in holy matrimony. Miss Beatrice McClelian sang "I Love You Truly" preceding the ceremony and Miss Martha Bryant played Lohengrin's Wedding March for the processional and Mendelssohn's at the close of the ceremony.

In the reception at the close of the wedding, ice cream and cake were served with appointments of green and white. There were forty-five guests present but not a single fellow appeared on the scene.

$$
\gg \gg
$$

\section{FRESHMAN WEEK}

Did you ever try to scrub stone steps with a tooth brush. Ask a freshman how he did it in the fall of 1936. Throughout the week freshman fellows were required to roll one pants leg, carry their books in a bucket, and with paint on their faces, go marching off to school. The girls wore hair ribbons on their pigtails and came to school with their dressesand aprons on backward. No freshman could enter through the front door of the College but had to get in some other way.

On the last day the fellows brought fishing poles and from the banks of the streets of Cedarville proceeded to fish from their buckets. After catching everything but fish, students proceeded to Willow Bend where the Freshmen and Sophomores battled it out; and what a battle. But after the rope had broken six times, the freshmen fell one by one into the cold waters of Massie's Creek.

\section{$\gg \gg$ \\ THE SING FEST}

The annual Sing Festival was held in the Alford Memorial Gymnasium on Thursday night, April 29, 1937. The entertainment was opened by melodious strains coming from behind the scenes. After the curtains had parted, the College Quartet appeared and gave a group of numbers, beginning with "Softly a Serenade." The second part of the program consisted of music rendered by the Girls' Glee Club. Besides the group singing, there was a solo-"Maytime", sung by Betty Tobias. She was later joined by Raymond Sisson, who aided her in giving a duet, "Will You Remember." The College Harmonizers added a bit of fun to the program after the more serious thoughts of spring and its inevitable companion, love. The program was concluded by Gilbert and Sullivan's Opera, "Trial by Jury," which was presented by the Mixed Chorus. The story centered around Margaret Nelson, who played the bride and was sueing her would be husband, Donald Foulks, because he left her waiting at the church. The Judge, James Anderson, solved the case by taking the bride for his own. "Trial by Jury" is a satire on the English Court System and was well presented by the Mixed Chorus. Other soloists were John Fox, Usher, Raymond Sisson, Attorney for the Plaintiff, and John Peterson, Head Juryman. 


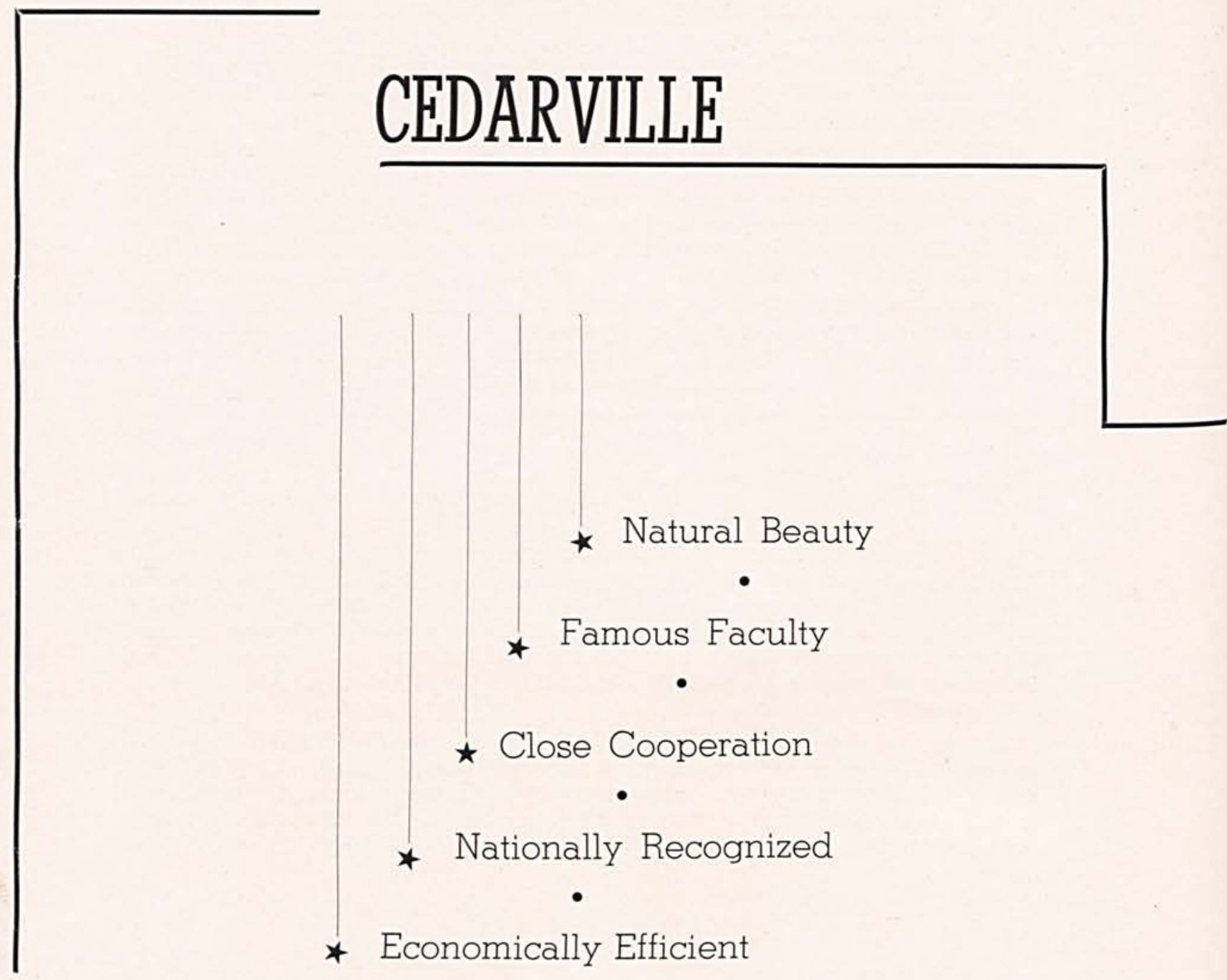




\section{COLLEGE}

The College is recognized by the Department of Public Education of the State of Ohio, and by the leading universities. The faculty is experienced and thoroughly trained.

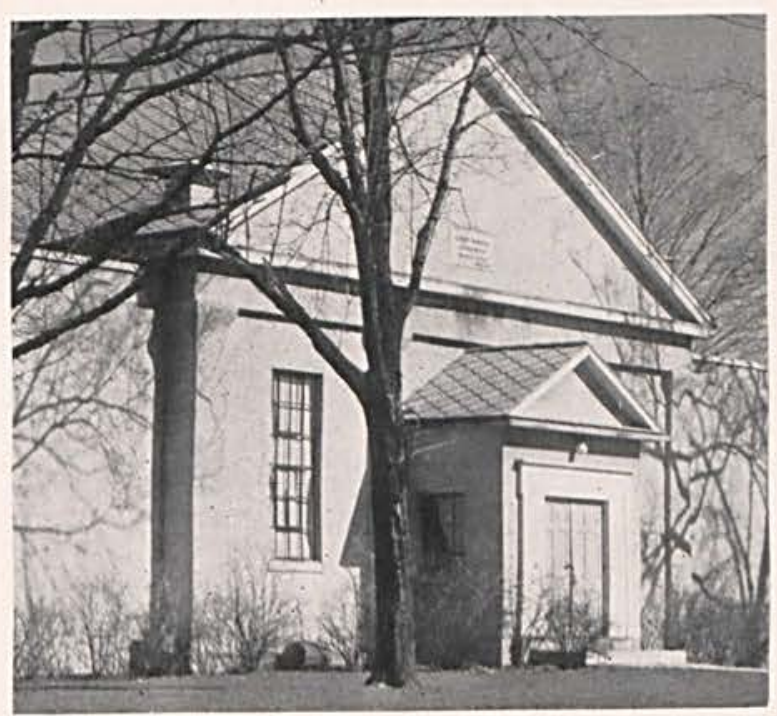

\section{COME TO CEDARVILLE COLLEGE}

Write for catalogue and information

W. R. McCHESNEY, Ph.D., D.D., President

Cedarville, Ohio 
September

7 First day of registration-More new guys!

9 C. C. starts her classes for a new year.

10 Y. W. Tea-U. Presbyterian Party. Girls held a pajama parade-boys-buckets-need we say more?

13 Convocation Service.

17 Auto Party at Guthrie's. Did you have your oil changed?

21 Cecil Thomas sends us to our radios. He speaks over WOSU.

22 Oooo my feet-musical games under direction of Tommy (Catherine) Thompson at Methodist Party.

24 First day of Freshman Initiation. They tried to pull a feed. You'll learn better.

27 Group Y. W. \& Y. M. members visited Bookwalter farm, Springfield.

29 Students show faculty they have lungs - snake dance.

October

5 Literary society takes two truck loads of yelling collegians on a hay ride. Hamburgers at Springfield.

8 Sophomores have party at gym. Tomlinson gets enough to eat. Imagine!

12 Dramatic Meeting-Whoever heard of making love with your backs turned to each other.

15 Y. M. \& Y. W. Mixer-Good time!

19 Literary-guest artists-Kelso, Gibson, Foulks, and McDonald.

21 Doris Watkins wins a ton of Cedarville's finest coal.

23 Prof. Hostetler tells us about the Old McGuffy readers.

28 Halloween party at gym. Jim Anderson, the devil, with Dorothy Anderson and Mary Johnston, his little devils, win first prize.

November

1 Men's Bible Reading Contest at M. E. Church-Kenneth Sanderson takes first place.

2 Chaplain Markle of the Navy speaks to Literary.

5 College basketeers start on season's work.

6 Coach gives out baseball letters.

19 Y. W. Committal.

23 Hampton Institute Sextet.

25-30 Thanksgiving Vacation.

December

6 Cedarville Mixed Chorus broadcasts from WHIO.

7 New Steinway piano for chapel.

8 Cedrus Staff Play-Jim Spiloted peed king and Dot knows how it feels to be a winner.

8 Cedrus Staff Play-Jim Spiloted peed king and Dot knows how it feels to be a weiner.

10 Debate squad wondering what Consumers' Co-operatives are - scavanger party-black cats--2 handled bean pots - "no trespassing" signs-What next?

15 Bluffton game.

16 Secret Pal Party-Into the wee hours girls hunted for their cars-Naughty boys.

18 Time out for Holidays.

Jānuary

5 Gosh! Vacation's gone.

13 Helen Seamon signed up NYA for 13 hours of reverence work-Oh my knees!

14 C. C. Yellow Jackets sting Defiance 33-19.

15 Practically everyone writing 10,000 word theme.

18 College Group pictures.

19-20-21 Exams, headaches, aspirin, bunk.

22 Exams over-breathing spell-Yellow Jackets beat Springfield YMCA 35-20.

25 Registration.

26 Ohio River floods scaring everyone.

27 C. C. beats Rio Grande 32-27.

28 C. C. debaters go to Bowling Green.

\section{HILL TOP GREENHOUSES}

H. C. FENKER, Florist

Phone 31

Jamestown, Ohio 


\section{Calendar}

February

1 Debaters win decision from Wilberforce.

2 Our boys bow to Wilmington 24-13.

4 Snake dance-Cold as Bixen.

5 Da yof Prayer.

6 Homecoming crowd fills the gym-C. C. loses to Rio Grande 29-27- - tight game.

7 " $B$ " Debaters speak in Dayton-Mrs. Ault is asked what she is doing with her father(Mr. Ault).

14 There's that little guy with the bow and arrows.

15 Cedarville drops a $36-27$ contest to Wilmington.

16 Chili supper-Y. W. at Geneva's-Boys seemed to think we were going to have the mock wedding.

17 Mr. Burns gets his ole blunderbuss after the boys again.

18 Rio Grande debaters find out how good our " A" bunch really are.

20 Yippee and a couple of Rah! Rah's! C. C. ties for conference Championship by drubbing Bluffton 49-27.

26 Eight sleepy debaters and two professors leave Cedarville at 6:30 A. M. for North Manchester, Indiana.

27 Debaters come home with eight victories and ten pairs of ear muffs.

March

2 Earthquake-Well shiver my timbers.

2, 4, 5 Dr. Rollin Walker, guest speaker in chapel.

9 Junior's wrestled the Sophomores out of the class tourney championship 22-20-12:45-Earthquake-practically scared me pink.

12 Sonja Henie, the skater, causes all the boys to forget their girls for a few days.

17 Y. M. elects Sanderson president-C. C. has Athletic banquet-Coach presents letters and numbers-Mr. Bearmore shows pictures of Olympics.

19 Y. W. Party at Bea. McClellan's-Mock wedding pulled off without a boy.

21 Mixed Chorus presents "The Holy City."

24 Rev, Hill showed Easter pictures in joint "Y."

27 Junior Class Play presented at the home of Mr. and Mrs. Steele.

30 Linton stars in Junior Class Play "Yours Truly Willie."

31 Spring Vacation.

April

1 April fool is her at last-You're the biggest fool I've passed.

7 Roller skating takes over the students' spare (?) moments. Earl Allison has to buy a new pair of trousers.

8 Frat pledges arrayed in pajama coats.

11 Women's Bible Reading Contest-Bertha Oleyar and Margaret Nelson tie for first.

13 Our big leaguers travel to Springfield for spring training.

15 Y. W. Carnival-Benny in "Ladies' Only" Booth.

20 Elmar, the Magician at Opera House. Dorothy chosen Queen-Johnny, Orator.

21 Jr. Class Party. Talk about eats! Oh, boy.

22 Cedarville College Entertainers go to Carlisle.

26 Regret to hear of the death of Rev. McMillan, president of the Board of Trustees.

27 College Quartet and Miss Basore entertain us in chapel.

29 What horse kicked Betty Fisher and Bertha Oleyar in the hip?

29 Sing Fest- "Trial by Jury."

May

13 Jr.-Sr. Banquet.

19 Dr. and Mrs. McChesney's reception for the students and faculty.

20 Mixed Chorus sings at Monroe High School graduation.

21 College Picnic.

30 Baccalaureate.

31 Music recital-Faculty reception.

June

1 Senior Class Play, "The Cat and the Canary."

2 Cedar Day.

4 Graduation.

\section{Leo Anderson, D.V.M.} VETERINARIAN

Phone 2-81
Cedarville, Ohio

\section{LANG CHEVROLET}

\author{
Xenia, Ohio
}




\section{THE CEDARVILLE HERALD}

\section{Commercial : Catalog Job Printing}

Let Us Give You An Estimate On Your Printing

\section{LUCILLE'S BEAUTY SHOP}

"Beauty Made More Beautiful"

$12 \frac{1}{2}$ North Detroit St.

Phone 234

Xenia, Ohio

\begin{tabular}{c|c}
\hline $\begin{array}{c}\text { Compliments of } \\
\text { Harner Electric Shop } \\
\text { Phone 1167 }\end{array}$ & $\begin{array}{c}\text { WRIGHT'S } \\
\text { White Villa Grocery } \\
\text { Cedarville, Ohio }\end{array}$ \\
5 East Main St. Xenia, Ohio & BROWN'S DRUGS \\
ThOUSE'S Rexall Store \\
GROCERY STORE & $\begin{array}{c}\text { The Best in Drug Store Service } \\
\text { Visit Our Fountain }\end{array}$ \\
Fruit : Meat : Vegetables & Main Street Cedarville, Ohio \\
Pedarville & Ohio 40
\end{tabular}

\section{COVAULT'S BEAUTY SHOP}

Every Beauty Service 


\section{The Hagar Strawboard and Paper Company}

CEDARVILLE, OHIO

Phone 39

STRAWBOARD FOR CORRUGATING PURPOSES

C. L. McGuinn

Coal • Feed • Seed

Grain and Wool

Miller Street

Phone 3
Compliments of

THE

COZY THEATER

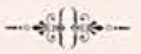

Cedarville, Ohio
Compliments of

\section{The}

Cedarville Grain

Company

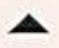

Complete Elevator Service

GRAIN - FEED - COAL FERTILIZER

SEED

Phone 21

C. P. ELGIN
Cedarville, $\mathrm{O}$.

L. R. JACOBS
T H E

CRITERION

$\rightarrow-4$ ff

Value First

Clothiers

XENIA, OHIO 


\section{THE FARMERS AND TRADERS BANK}

Established 1867

Jamestown, Ohio

Hamman's Dairy

Milk

SINGLE and WHIPPING

CREAM
Phone 197-R3 Cedarville, O.

\section{Nagley's \\ Grocery}

"THE CORNER STORE"

\section{THE CEDARVILLE LUMBER COMPANY}

International Harvester Implements

Phone 33

Cedarville, Ohio
The Alexander

Department Store

Phone 421

-

Yellow Springs, $\mathrm{O}$.

EVANS

RESTAURANT

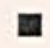

Xenia Avenue
Phone 58
Cedarville, $\mathrm{O}$.

Anderson's Flower Shop

49 West Main Street

Phone $681 \quad$ Xenia, Ohio
Compliments

of

JOHN ALLEN

BARBER SHOP

Cedarville, Ohio 


\section{CUMMINGS and CRESWELL}

Coal : Feed : Grain

Wool : Livestock

Phone 100

Cedarville, Ohio

PAUL EDWARDS

DODGE - PLYMOUTH

DODGE TRUCKS

Used Cars

S. Main St., Phone 147, Cedarville, O.

Alice Rinck's Hat Shop

8 West Main Street

XENIA, OHIO

Waxler Furniture Store

East Main Street

Phone 422
C. E. MASTERS

GROCERY and MEAT

Phone 44

Cedarville, $\bigcirc$.
Mel Johnson

BARBER and BEAUTY SHOP

120 South Detroit St.

Phone 405

Xenia, Ohio

The Dairy Stores

EDGAR CAREY

Phone 138

Jamestown, $\mathrm{O}$.

THE XENIA NATIONAL BANK

One Hundred and Two Years

Of Community Service

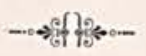




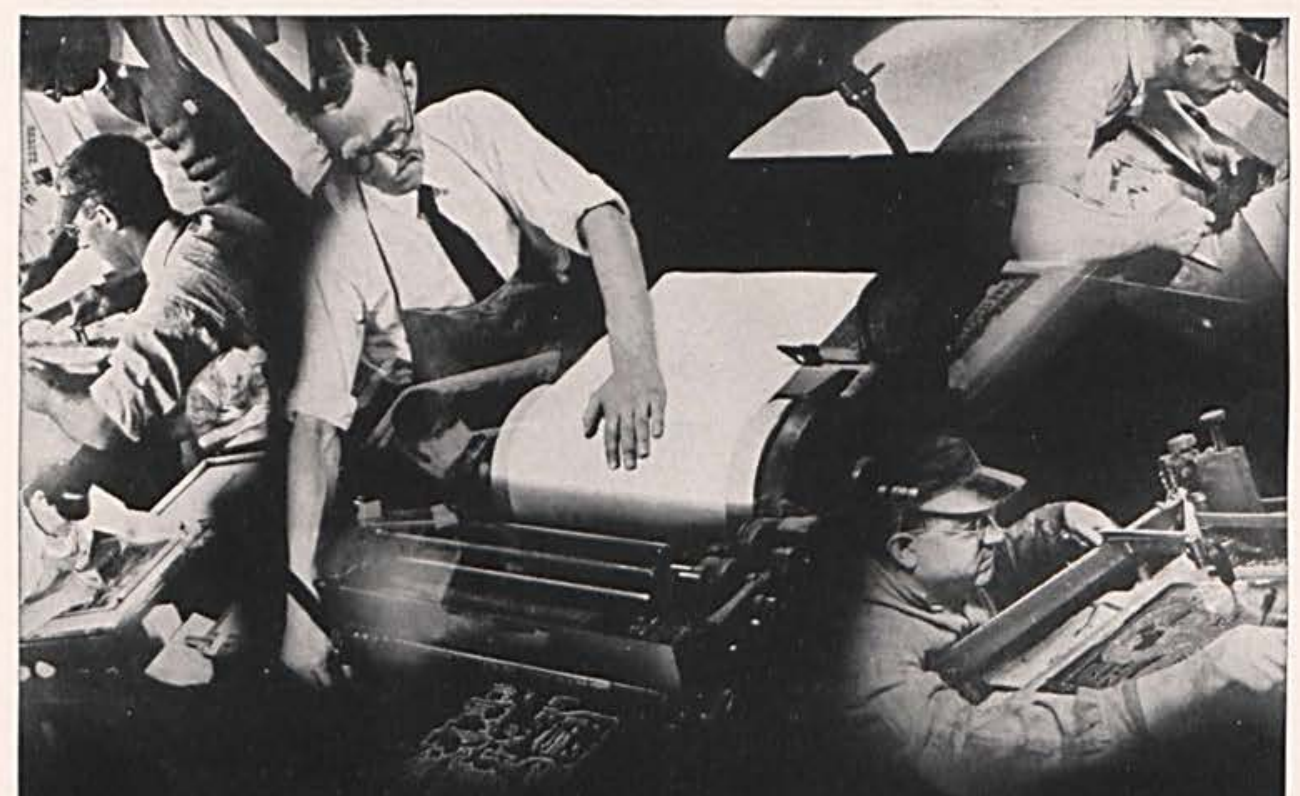

MASTER ENGRAVERS TO AMERICA'S SCHOOLS

7. Constantly alert for new ideas, better ways of doing things... Pontiac has sponsored outstanding improvements in yearbook design and engraving procedure. The name "Pontiac" is and will continue to be your guarantee of unquestionable quality and complete satisfaction.

PONTIAC ENGRAVING \& ELECTROTYPE CO. 812-822 WEST VAN BUREN ST. (Chieftain BIdg.) CHICAGO, ILLINOIS

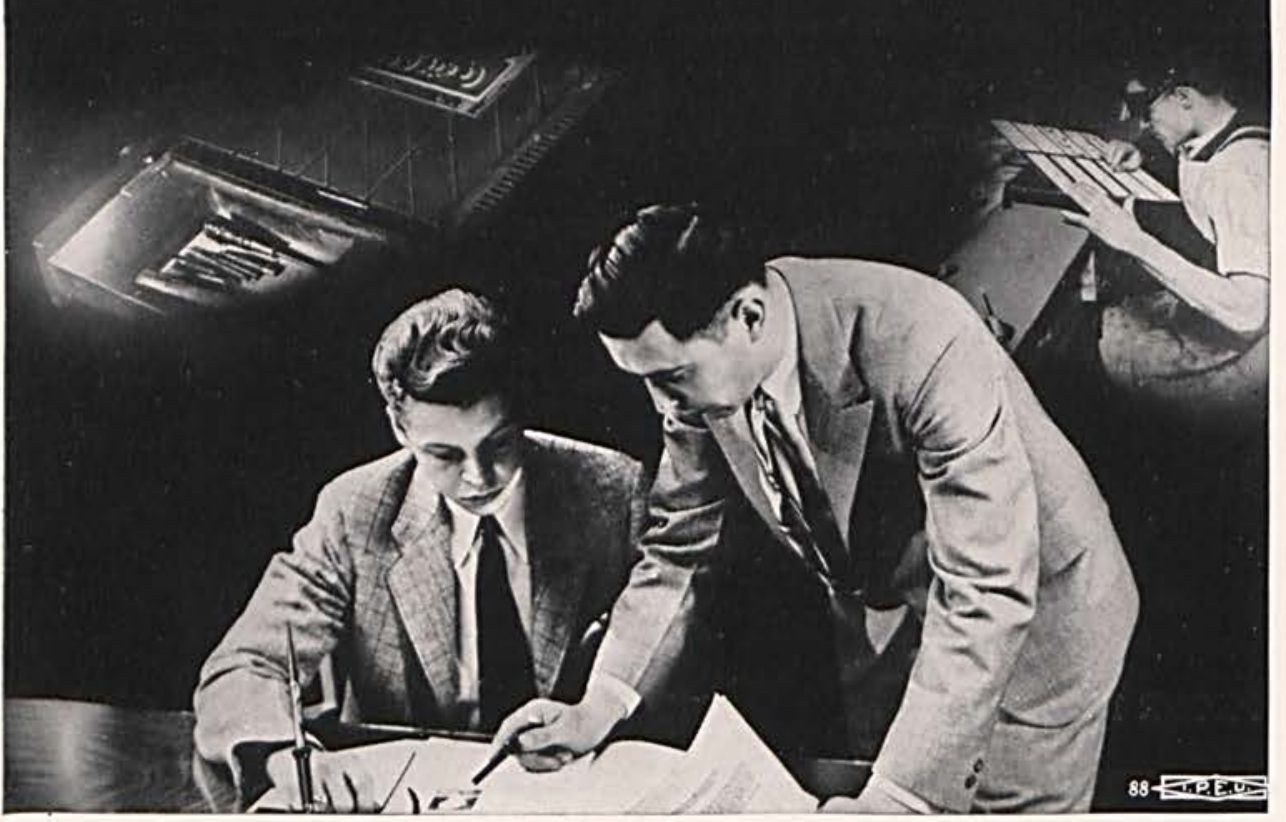


A U T O GRAPHS 


\section{A U T O G R A P S}





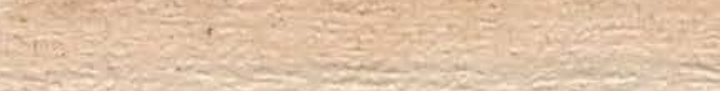

5

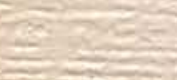


